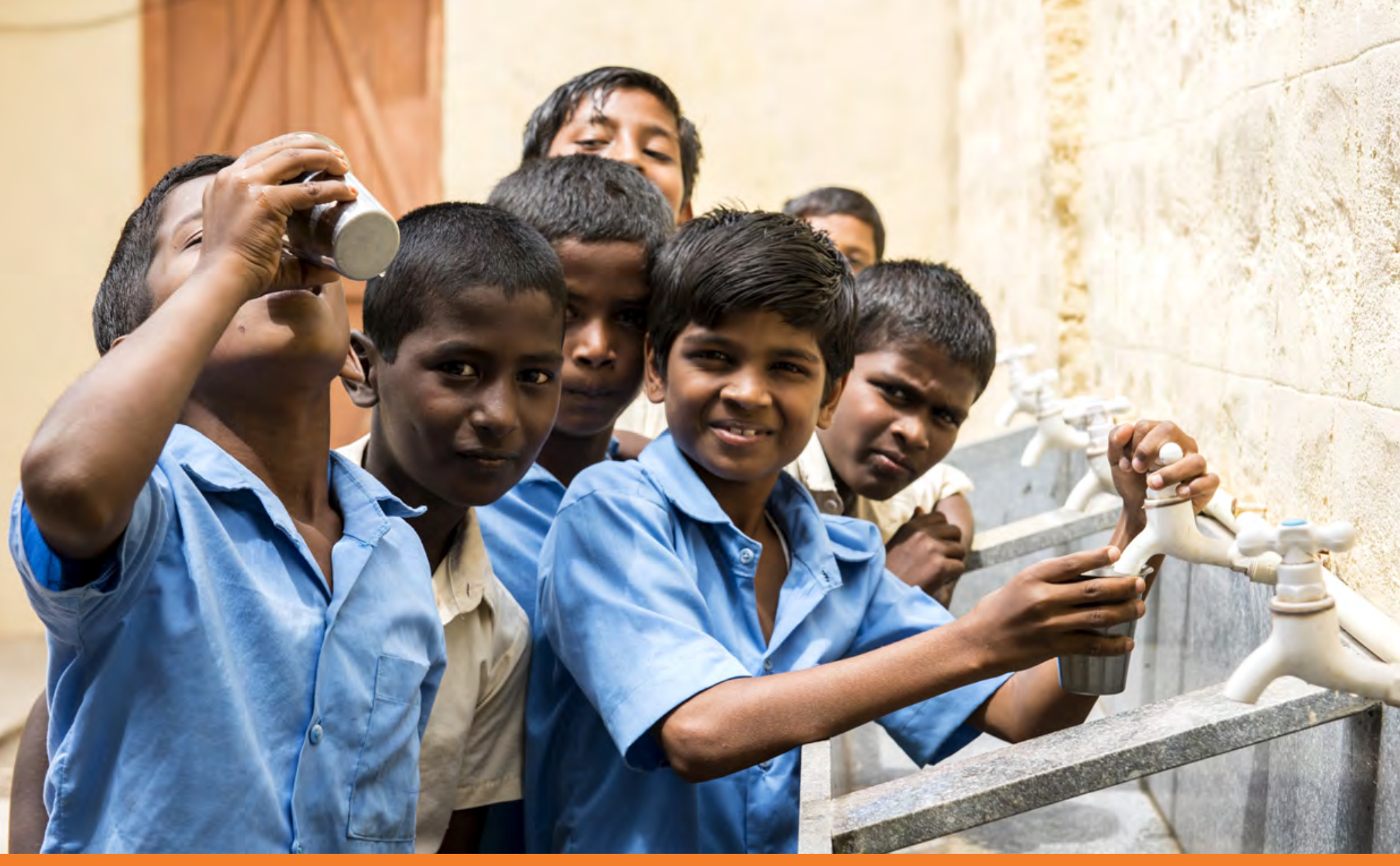

DEVELOPMENT EFFECTIVENESS BRIEF

INDIA AND ADB

THREE DECADES OF ENDURING PARTNERSHIP

DECEMBER 2018 


\section{DEVELOPMENT EFFECTIVENESS BRIEF}

INDIA AND ADB

THREE DECADES OF ENDURING

PARTNERSHIP

DECEMBER 2018 
(c) 2018 Asian Development Bank

6 ADB Avenue, Mandaluyong City, 1550 Metro Manila, Philippines

Tel +632632 4444; Fax +6326362444

www.adb.org

Some rights reserved. Published in 2018.

ISBN 978-92-9261-446-1 (print), 978-92-9261-447-8 (electronic)

Publication Stock No. BRF189782

DOI: http://dx.doi.org/10.22617/BRF189782

The views expressed in this publication are those of the authors and do not necessarily reflect the views and policies of the Asian Development Bank (ADB) or its Board of Governors or the governments they represent. By making any designation of or reference to a particular territory or geographic area, or by using the term "country" in this document, $\mathrm{ADB}$ does not intend to make any judgments as to the legal or other status of any territory or area.

This work is available under the Creative Commons Attribution 3.0 IGO license (CC BY 3.0 IGO) https://creativecommons.org/licenses/by/3.0/igo/. By using the content of this publication, you agree to be bound by the terms of this license. For attribution, translations, adaptations, and permissions, please read the provisions and terms of use at https://www.adb.org/terms-use\#openaccess.

This CC license does not apply to non-ADB copyright materials in this publication. If the material is attributed to another source, please contact the copyright owner or publisher of that source for permission to reproduce it. ADB cannot be held liable for any claims that arise as a result of your use of the material.

Notes:

In this publication, "\$" refers to United States dollars.

Corrigenda to ADB publications may be found at http://www.adb.org/publications/corrigenda. 


\section{CONTENTS}

Abbreviations $\quad$ iv

Weights and Measures $\quad$ v

India Development Indicators $\quad$ vi

1 India and ADB: Three Decades of Enduring Partnership 1

1.1 Country Context 3

1.2 ADB Assistance to India 4

2 ADB Contribution to Faster, More Inclusive, and Sustainable Development 8

2.1 Transport: Gaining Momentum 8

$\begin{array}{ll}\text { 2.2 Urban Development: Fulfilling Aspirations } & 14\end{array}$

$\begin{array}{ll}2.3 \text { Energy: Brighter Prospects } & 20\end{array}$

2.4 Agriculture and Natural Resources: Prosperity for Posterity 23

2.5 Human Development: Investing for the Future 26

2.6 Leveraging Finance for Infrastructure 28

$\begin{array}{ll}2.7 & \text { Private Sector Operations } \\ 2.89\end{array}$

2.8 Catalyzing Private Sector Investments for Enhanced Impact 32

2.9 Advancing Subregional and Regional Cooperation 33

2.10 Developing Economic Corridors: New Approaches for Infrastructure 36

2.11 Promoting Gender Equality and Social Inclusion 37

3 Improving Operational and Organizational Effectiveness $\quad 40$

3.1 Improving Portfolio Performance $\quad 40$

3.2 Strengthening Processes for Greater Effectiveness 42

3.3 Investing in Long-Term National Capacities 43

3.4 Capacity Development 43

3.5 Strengthening Knowledge Development 45

$\begin{array}{lll}4 & \text { The Future } & 47\end{array}$

$\begin{array}{ll}\text { References } & 48\end{array}$ 


\section{ABBREVIATIONS}

\begin{tabular}{|c|c|}
\hline ADB & Asian Development Bank \\
\hline BIMSTEC & Bengal Initiative for Multi-Sectoral Technical and Economic Cooperation \\
\hline CDRC & Capacity Development Resource Center \\
\hline DDU-GKY & Deen Dayal Upadhyaya Grameen Kaushalya Yojana \\
\hline ECEC & East Coast Economic Corridor \\
\hline EGM & effective gender mainstreaming \\
\hline FIDIC & International Federation of Consulting Engineers \\
\hline FY & fiscal year \\
\hline GDP & gross domestic product \\
\hline GEN & Gender equity \\
\hline GETCO & Gujarat Energy Transmission Corporation Limited \\
\hline GOI & Government of India \\
\hline GSDP & gross state domestic product \\
\hline LIS & low-income states \\
\hline MDG & Millennium Development Goal \\
\hline MSMES & micro, small, and medium-sized enterprises \\
\hline NHDP & National Highways Development Project \\
\hline $\mathrm{NITI}$ & National Institution for Transforming India \\
\hline O\&M & operation and maintenance \\
\hline OCR & ordinary capital resources \\
\hline PMGSY & Pradhan Mantri Gram Sadak Yojana (Prime Minister's Rural Road Program) \\
\hline POWERGRID & Power Grid Corporation of India Limited \\
\hline PPP & public-private partnership \\
\hline PSM & public sector management \\
\hline PSOD & Private Sector Operations Department \\
\hline $\mathrm{RCl}$ & regional cooperation and integration \\
\hline $\mathrm{RCIP}$ & Rural Connectivity Investment Program \\
\hline RUIDP & Rajasthan Urban Infrastructure Development Program \\
\hline SAARC & South Asian Association for Regional Cooperation \\
\hline SASEC & South Asia Sub-Regional Economic Cooperation \\
\hline SDG & Sustainable Development Goal \\
\hline SHG & self-help group \\
\hline TA & technical assistance \\
\hline $\mathrm{VCIC}$ & Visakhapatnam-Chennai Industrial Corridor \\
\hline WBDFP & West Bengal Development Finance Program \\
\hline
\end{tabular}




\title{
WEIGHTS AND MEASURES
}

\author{
GW gigawatt \\ km kilometer \\ m meter \\ MVA megavolt-ampere \\ MW megawatt
}




\section{INDIA DEVELOPMENT INDICATORS}

\section{Country at a Glance}

GDP ( $\$$ billion)

Per capita GDP (\$)

Population (millions)

Population growth (4-year average) (\%)

GDP growth (5-year average) (\%)

Literacy rate (\%)

Sustainable Development Goals (SDGs)

Population living on less than $\$ 1.90$ a day (\%)

Population living below the national poverty line (\%)

Prevalence of Undernourishment (\%)

Under-5 mortality rate, per 1,000 live births

Mortality rate, infant (per 1,000 live births)

Proportion of seats held by women in national parliaments (\% of total number of seats)

Proportion of population using safely managed drinking water services, rural (\%)

Proportion of population using safely managed sanitation services, by rural (\%)

Proportion of population with access to electricity (\%)

Proportion of urban population living in slums (\%)

Carbon dioxide emissions per unit of GDP (kilograms of $\mathrm{CO}_{2}$ per constant 2010 United States dollars)

Sources: Reserve Bank of India. Database of the Indian Economy. https://dbie.rbi.org.in (accessed 9 August 2018); and United Nations. Global SDG Indicators Database. https://unstats.un.org/sdgs/indicators/en/\# (accessed 9 August 2018).
2005

2017

808.9 $2,531.3$

$707.0 \quad 1,923.3$

1,144 1,316

1.6

5.7 1.3
2005

2017

38.2 (2004)

$37.2(2004) \quad 21.9(2011)$

$74.4 \quad 39.0$ (2016)

$55.7 \quad 34.0(2016)$

$8.3 \quad 11.8$

$35.6 \quad 49.4$ (2015)

16.430 .5 (2015)

66.984 .5 (2016)

$34.8 \quad 24.0(2014)$

$0.3 \quad 0.28(2015)$
20.514 .5 (2015) 


\section{INDIA AND ADB: THREE DECADES OF ENDURING PARTNERSHIP}

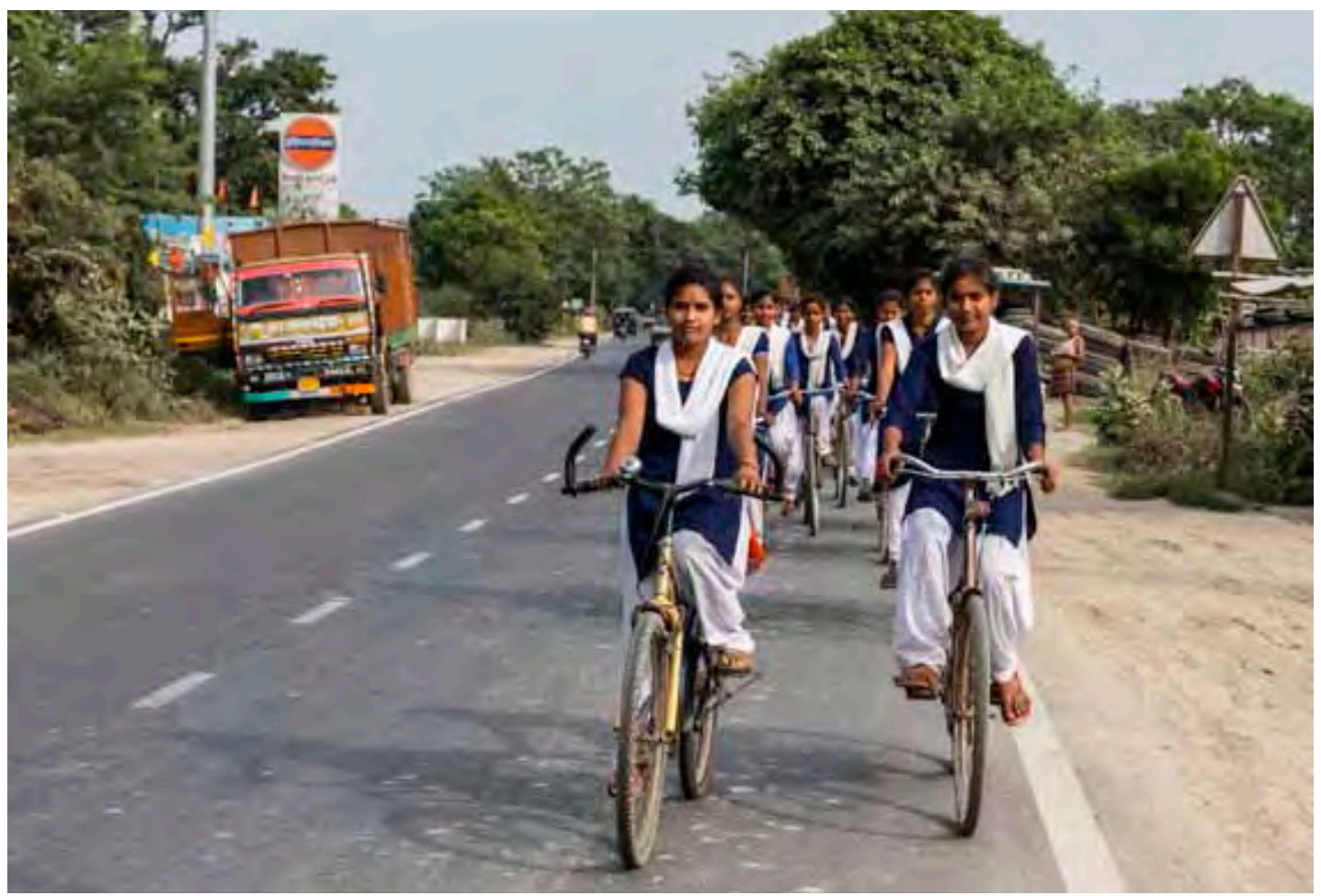

In 2007, Suresh Kumar was posted to the Government Senior Secondary School in Maghar-about 100 kilometers $(\mathrm{km})$ from Patna, the capital of Bihar. It was a daily struggle for Kumar and his 300 students to reach the school. "The road was merely a dirt track, full of potholes. The bus driver would often ask passengers to get down before driving over some of the bigger potholes," says Kumar, the school principal, as he reminisced about his commute from the district town of Siwan. It used to take up to 2 hours for the bus to cover the 30-km distance on State Highway-73.

The situation changed drastically once the road was upgraded to two lanes as part of the assistance of the Asian Development Bank (ADB) to Bihar. It now takes Kumar only 30 minutes to reach Siwan. In 4 years since the road upgrade, school enrolment had risen to 1,400-including more than 800 girls-in 2017. The improved connectivity to nearby villages encouraged girls to commute to school on bicycles. Hordes of girls cycling to and from school is a common sight along the highway.

About $70 \mathrm{~km}$ away on the same highway, Khushi Kumari-a Class 10 student at Sri Yamunachari High School in Daryapur - is happy to ride her bicycle. "Earlier, the road was so bad that I would need to get down to haul the bicycle over potholes. It is a smooth and pleasant ride now," says 15-year-old Kumari. Nargis Khatoun, Kumari's classmate whose home is $5 \mathrm{~km}$ away from the school, says she can now arrive for class in 15 minutes, from the 30-minute to 40-minute travel time it used to take her.
Cycling to school. Students of the Government Senior Secondary School pass by $\mathrm{SH}-73$, about 100 kilometers from Patna, the state capital of Bihar (photo by ADB). 
Smooth ride. Khushi Kumari, a Class 10 student of

Sri Yamunachari

High School at

Daryapur, about 35

kilometers from Patna

(photo by ADB).

Saving lives.

Dr. Jyoti Sharan attending to patients at a community health center in Masharak, about $100 \mathrm{~km}$ from the state capital Patna

(photo by ADB).
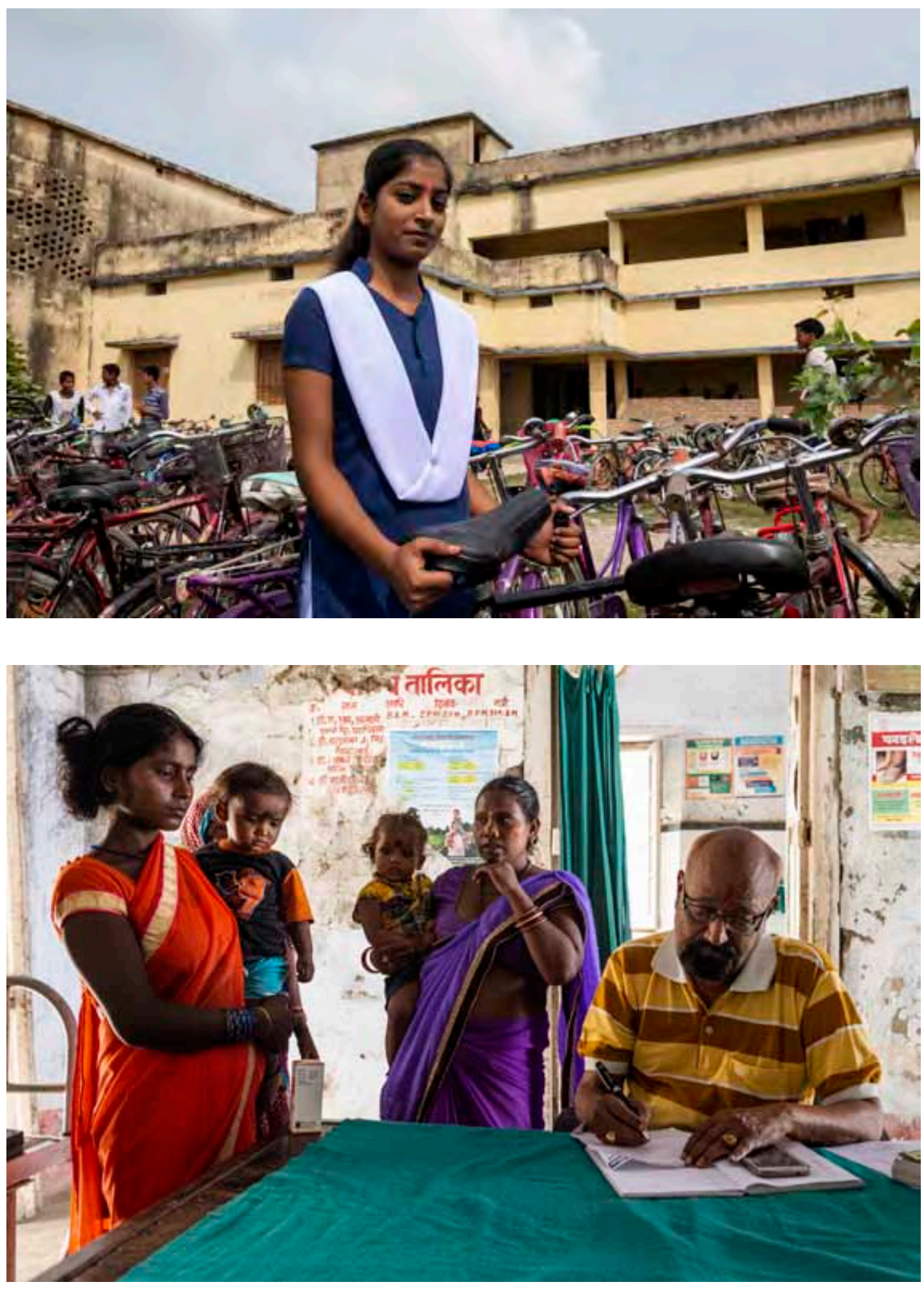

Overall, the ADB-assisted road improvements in Bihar have reduced vehicle travel time by about $55 \%$.

The road improvements have also helped improve access of the rural poor to social services. For example, travel time to health care facilities in the area has been reduced by at least $50 \%$. 
"With better roads, valuable time is saved in bringing critical patients to hospital. This has helped in saving lives," says Dr. Jyoti Sharan from the Community Health Center in Masharak.

The hospital has seen a steady rise in daily patient registration from about 50 per day in 2014 to 150 per day in 2017. Births at the health center also increased from 3 per day to 10 per day during the same period as better roads enabled village health workers to bring in pregnant women for safer deliveries.

Through projects like these, ADB has been partnering with the government for over 30 years to build the infrastructure needed to improve connectivity and access to economic opportunities and social services - facilitating institutional development and capacity building.

\subsection{Country Context}

India is undergoing a rapid economic transformation toward becoming an upper middle-income country. Annual economic growth averaged 7.1\% between the fiscal years (FYs) 2013 and 2017, placing India among the world's fastest growing large economies (ADB, 2018a). ${ }^{1}$

It is now the third-largest country worldwide (in purchasing power parity terms). This growth has been accompanied by progressive reform measures to improve the country's economic competitiveness and achieve more inclusive and sustainable growth. These include simplifying the tax structure through the introduction of a goods and services tax, improving the ease of doing business, enhancing infrastructure investments, and increasing agricultural productivity.

The country has also achieved many of the Millennium Development Goals (MDGs). These MDGs include halving the proportion of people living in poverty, eliminating gender disparity in education, containing the spread of major diseases, and increasing access to safe drinking water (Government of India [GOI], 2017a).

Despite these successes, several development challenges remain. India has a large number of poor people; official surveys estimate nearly 270 million or $21.9 \%$ of the population were living in poverty in FY2011 (GOI, 2013). With many youths entering the labor force every year and nearly 47\% of the workforce engaged in low-productivity agriculture, structural transformation and job creation in modern sectors are urgently needed. India has also fallen short of achieving MDGs related to improving maternal health, ensuring environmental sustainability, and eradicating hunger.

India's infrastructure deficit constrains economic competitiveness and job creation. ${ }^{2}$ Infrastructure bolsters inclusive growth by enhancing the efficiency of the production and distribution of commodities, providing new economic opportunities, and improving human capabilities.

The country also needs to improve service delivery in urban centers to respond to rapid urbanization. Cities could be transformed into commercial and industrial hubs with improved standards of living to also promote growth. To do this, cities must be more efficient in urban planning, land-use governance, and floor area regulations. They should also improve revenue potential through better taxation and cost recovery of investments.

\footnotetext{
${ }^{1}$ The fiscal year (FY) begins on 1 April. FY before a calendar year denotes the year in which the fiscal year begins, e.g., FY2017 begins on 1 April 2017 and ends on 31 March 2018.

2 According to the Government of India (GOI) (2018a), India needs a cumulative $\$ 4.5$ trillion for infrastructure investment up to 2040 .
} 
Environmental sustainability is another challenge faced by India due to air and water pollution, forest degradation, water resource depletion, and the impact of climate change. Additionally, the country needs to bridge income and growth disparities between advanced and low-income states (LIS), so that LIS can significantly contribute to the country's growth.

The government's development strategy focuses on overcoming these challenges. Its key pillars include

(i) improving the living standards of citizens by doubling farmers' incomes and creating well-paid jobs in modern industrial sectors;

(ii) developing inclusive infrastructure in urban and rural areas;

(iii) ensuring equitable access to social services with substantial improvements in the quality of delivery;

(iv) enhancing governance and institutional capacity; and

(v) addressing environmental challenges.

The "Make in India" initiative promotes industrialization and generates employment in the manufacturing sector by developing industrial corridors and manufacturing hubs, facilitating business, and easing foreign investment caps.

The Bharatmala and Sagarmala initiatives will bridge gaps in the existing highways and port infrastructure, significantly increase the efficiency of movement of passengers and freight, and reduce logistics costs.

Other key initiatives such as "Skill India" will bolster the competitiveness of the manufacturing sector by improving people's skills to enhance their employability. The aim of the Smart Cities and Atal Mission for Rejuvenation and Urban Transformation programs is to establish dynamic urban hubs across the country to transform urban areas into livable cities that can drive rapid growth in modern industries. "Digital India" is extending digital infrastructure providing a platform for efficient public administration and service delivery.

The government also seeks to improve the livelihood of people in rural areas by providing power to all households under the "Power for All" initiative and extending road connectivity to all villages under the Prime Minister's Rural Road Program (PMGSY) by 2019.

The country's commitment to inclusive and sustainable growth is shown by ambitious targets for the implementation of the Sustainable Development Goals (SDGs). Individual, national, and state development agendas are aligned with the SDGs.

With decades of support to India, ADB has continuously aligned its assistance to country needs and government priorities.

Between 1986 and 2017, the

total sovereign and nonsovereign loan commitment for India was $\$ 39.8$ billion.

\subsection{ADB Assistance to India}

Although India is a founding member of ADB, the country started availing of assistance only in 1986. The India-ADB partnership has deepened and strengthened over the past 3 decades and responded to the evolving development priorities and flagship initiatives of the government.

Operations of ADB are guided by the country partnership strategy, which aims to support India's development objectives and is prepared in close consultation with the government and other stakeholders. ADB operations in the country now span six sectors: transport, energy, water and urban services, finance and public sector management, agriculture and natural resources, and human development (Table 1 and Figures 1-3). 
$A D B$ endeavors to integrate the key priority of inclusive economic growth. The bank's support for the development of state roads, expansion of rural connectivity, and promotion of tourism facilitate inclusive growth by connecting poor people to markets and enhancing their access to productive assets. Projects supporting skill acquisition, improved urban infrastructure, and equitable access to quality health services help promote greater access to economic opportunities by strengthening the capacities of the poor and vulnerable.

ADB operations also contribute to environmentally sustainable growth. Projects cover areas including railways and mass rapid transit system; renewable energy and energy efficiency; coastal protection, river bank strengthening, and river basin management; and urban environmental management, including water management, sanitation, and sewerage and solid waste management.

Assistance to India goes beyond physical investment. ADB leverages finance, partnerships, and knowledge; fosters sharing and adoption of global and regional good practices; and includes capacity development as an integral element of its operations.

ADB-supported operations also aim to leverage the access of women to resources and opportunities that would enhance their involvement and participation to drive economic growth.

The ADB program extends across 25 states, including LIS where the technical and financial assistance needs are greater. About $62 \%$ of ADB's current portfolio in India is in LIS.

Another important area of ADB support covers the development of economic corridors using a multi-sector and holistic approach. This could facilitate integration with global value chains, while supporting India's emerging role in regional cooperation.

Table 1: ADB's Loan Commitments to India, 1986-2017

(\$ million)

\begin{tabular}{|c|c|c|c|c|c|c|}
\hline ADB Lending & $1986-2013$ & 2014 & 2015 & 2016 & 2017 & $1986-2017$ \\
\hline OCR sovereign & $26,726.0$ & $2,826.5$ & $2,177.7$ & $1,248.0$ & $2,755.5$ & $35,733.7$ \\
\hline OCR nonsovereign ${ }^{a}$ & $1,999.4$ & 375.0 & 365.0 & 509.1 & 809.6 & $4,058.1$ \\
\hline Total & $28,725.4$ & $3,201.5$ & $2,542.7$ & $1,757.1$ & $3,565.1$ & $39,791.8$ \\
\hline
\end{tabular}

$\mathrm{OCR}=$ ordinary capital resources

a The total includes private and public sector nonsovereign operations.

Source: ADB.

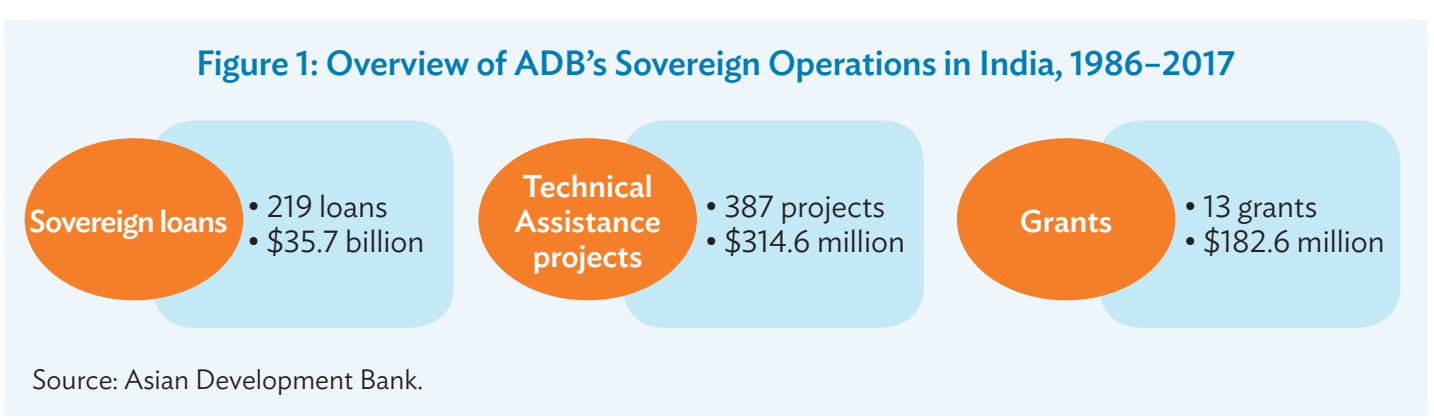


Figure 2: Sector Distribution of ADB's Sovereign Loan Commitments to India, 1986-2017

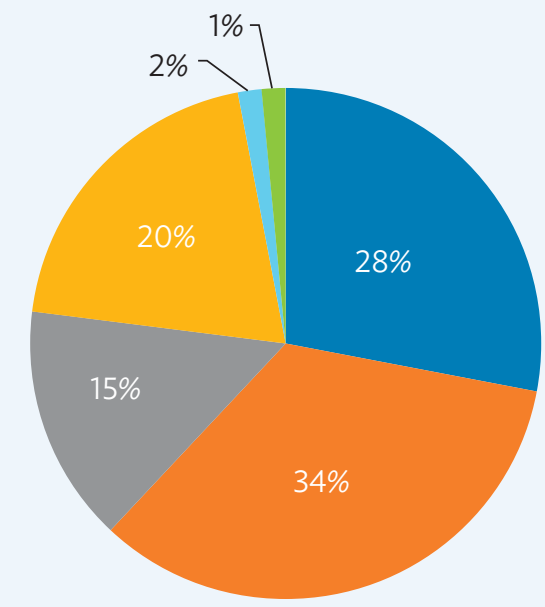

Energy (59 loans, \$9,985 million)

- Transport (123 loans, \$12,365 million)

- Urban development and multisector (42 loans, \$5,264 million)

- Finance and public sector management (39 loans, \$7,040 million)

Agriculture and natural resources (10 loans, \$579 million)

Education and health (3 loans, \$500 million)

Source: Asian Development Bank.

Figure 3: ADB's Sovereign Loan Commitments to India by Sector, 1986-2017

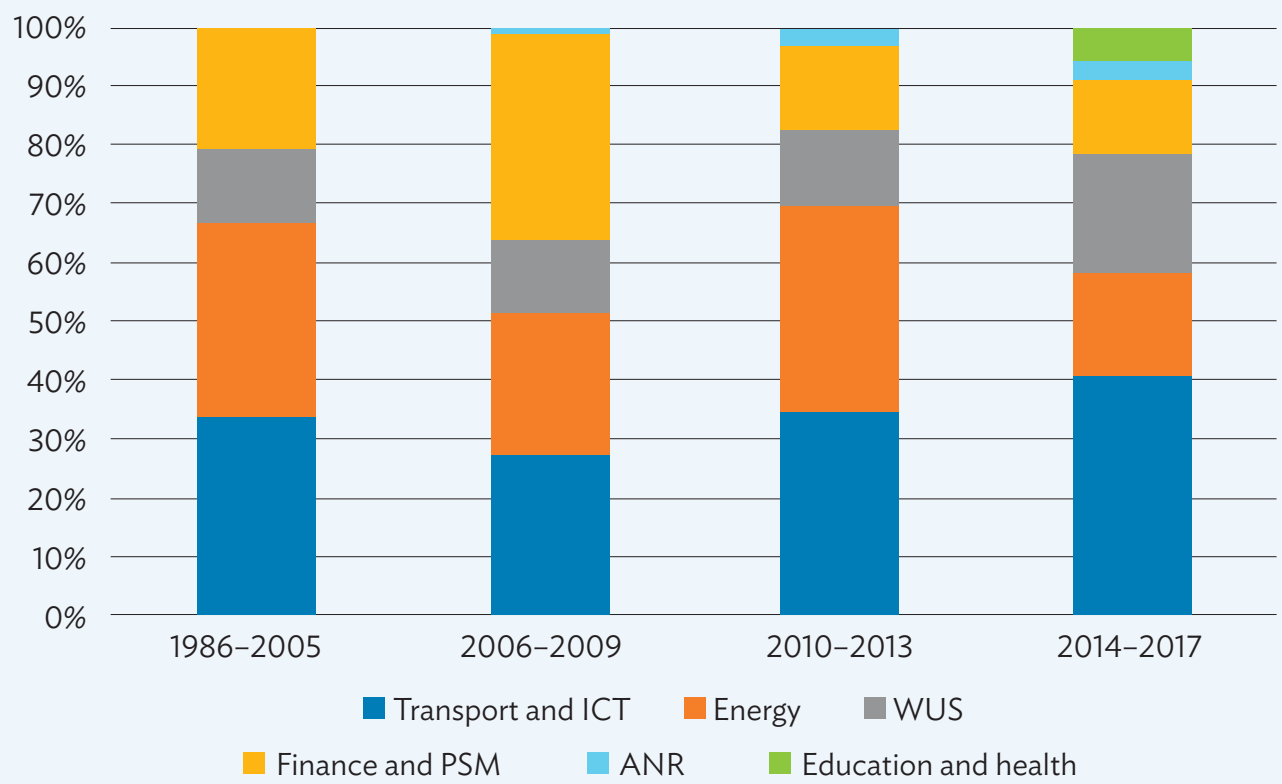

ANR = agriculture and natural resources, ICT = information and communications technology, PSM = public sector management, WUS = water and other urban infrastructure and services.

Source: Asian Development Bank.

As of 31 December 2017, ADB's portfolio comprised 79 sovereign loans totaling about $\$ 12.9$ billion. Transport and energy account for about two-thirds while urban development projects constitute one-fifth of the current assistance (Figure 4). This is complemented by the technical assistance (TA) program supporting strategic studies to identify priority investments, project preparation, and capacity development, which underpin a robust lending program and a well-performing portfolio. 
Figure 4: Sector Distribution of ADB's Ongoing Sovereign Projects, as of 31 December 2017

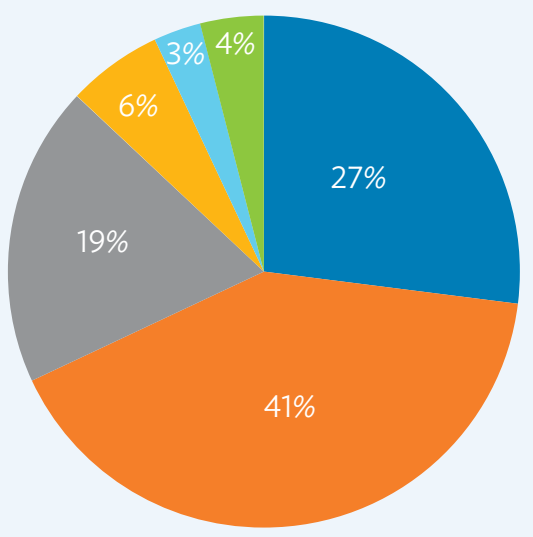

Energy (21 loans, \$3,465 million)

- Transport (22 loans, \$5,292 million)

- Urban development and multisector (23 loans, $\$ 2,460$ million)

- Finance and public sector management (4 loans, \$805 million)

- Agriculture and natural resources (6 loans, \$412 million)

Education and health (3 loans, \$500 million) 


\section{ADB CONTRIBUTION TO FASTER, MORE INCLUSIVE, AND SUSTAINABLE DEVELOPMENT}

ADB has forged a strong partnership with India and contributed to improving the quality of life of millions of people since it began operations in the country in 1986.

Projects have provided better road connectivity; electricity connections; and improved water supply, sanitation, and solid waste management facilities. They have improved land through irrigation, drainage, and flood management; and reduced vulnerability to floods. They have created opportunities for education and skills development. Operations have contributed directly, indirectly, and in a mutually reinforcing manner, to enhanced livelihood and job opportunities, increased access to education and health services, better living conditions, and improved economic and social indicators for many people in India.

ADB contributes to development initiatives in India through projects and technical assistance. Table 2 presents the development results of ADB-supported initiatives during 2014-2017, giving a snapshot of changes they have brought.

\subsection{Transport: Gaining Momentum}

There is a close relationship between economic growth and infrastructure, in which transport infrastructure plays a significant role. Over time, roads have emerged as the predominant mode of transport in terms of traffic share as well as their contribution to the national economy. Road development received particular attention and has been prioritized under government programs such as the National Highway Development Project (NHDP) launched in 1998 and the PMGSY launched in $2000 .^{3}$

India's road network is large and has increased from about 3.37 million kilometers $(\mathrm{km})$ in 2001 to over 5.6 million $\mathrm{km}$ in 2017. National and state highways and expressways account for around $5 \%$ of the road network, while district roads and village roads constitute the rest (GOI, 2018a). For the road subsector, improving connectivity, maintenance, and safety are key priorities of the government. In October 2017, the government launched Bharatmala Pariyojana, a new umbrella program for highways that focuses on optimizing the efficiency of freight and passenger movement across the country.

\footnotetext{
3 The PMGSY is a centrally sponsored program implemented in partnership with state governments to provide good allweather road connectivity to unconnected villages and habitations.
} 
Table 2: Development Results of ADB-Supported Operations in India

\begin{tabular}{lc} 
& \\
Sector & Results Achieved \\
\cline { 2 - 2 } Transport & $\mathbf{2 0 1 4 - 2 0 1 7}$ \\
Use of roads built or upgraded (average daily vehicle-km in the first full year of & \\
operation) & $19,692,776$ \\
\hline Roads built or upgraded (km) & 10,239 \\
\hline Expressways and national highways (km) & 1,483 \\
\hline Provincial, district, and rural roads (km) & 8,755 \\
\hline Energy & \\
\hline Greenhouse gas emission reduction (tCO2-equivalent per year) & 155,573 \\
\hline Installed energy generation capacity (MW equivalent) & 4,113 \\
\hline Renewable (MW equivalent) & 4,113 \\
\hline Transmission lines installed or upgraded (km) & 4,764 \\
Distribution lines installed or upgraded (km) & 29,468 \\
\hline Water and other urban infrastructure and services & \\
\hline Households with new or improved water supply (number) & $1,625,465$ \\
\hline Households with new or improved sanitation (number) & 225,934 \\
\hline Wastewater treatment capacity added or improved (cubic meters per day) & 105,000 \\
\hline Households with improved Solid Waste Management facilities (number) & $5,000,000$ \\
\hline Water supply pipes installed or upgraded (length of network in km) & 3,470 \\
\hline Households with reduced flood risk (number) & 243,387 \\
\hline Land improved through irrigation, drainage and/or flood management (ha) & \\
\hline & \\
\hline
\end{tabular}

$\mathrm{tCO}_{2}=$ tons carbon dioxide, ha = hectare, $\mathrm{km}=$ kilometer, $\mathrm{MW}=$ megawatt

Sources: Project Completion Reports; ADB results online.

Under Bharatmala, $53,000 \mathrm{~km}$ of national highways have been identified as requiring work to improve national corridor efficiency. Of these, around $24,800 \mathrm{~km}$ are to be taken up by $2021 \mathrm{in}$ the first phase of implementation (GOI, 2018b). ${ }^{4}$ In addition, the first phase also includes 10,000 km of remaining road works from NHDP. In view of the large road network, the planning, development, and funding for these roads need to be scaled up significantly, with increasing mobilization of private capital.

In FY2014, 1,140 billion-passenger $\mathrm{km}$ and 682 billion net-ton $\mathrm{km}$ were transported by Indian Railways (GOI, 2017b). Despite its extensive reach and scale, the share of railways in the total

${ }^{4}$ Bharatmala Pariyojana aims to bridge critical infrastructure gaps through interventions such as development of economic corridors, intercorridor, and feeder routes, national corridor efficiency, border and international connectivity routes, coastal and port connectivity roads, and greenfield expressways. (GOI, 2018b). 
surface freight carried is declining. Railways also suffer from low capacity, poor utilization of existing capacity, safety issues, and lack of quality service delivery in the passenger segment. The government has taken several initiatives to address these issues through the construction of new dedicated freight corridors, capacity augmentation of existing corridors, modernization of technology, tariff rationalization, development of high and semi-high-speed rail corridors, and station redevelopment and modernization as well as the improvement of passenger amenities, service delivery and efficiency, and safety.

Many cities in India, particularly metros, experience traffic congestion and air pollution. Efficient and sustainable transport systems and mobility are critical to the smooth functioning of the city economy and labor markets. To address these issues, measures are being taken to provide public transport. Higher capacity rail-based mass transit systems (metro rail) have emerged as one solution. Following the success of the Delhi Metro project, 15 cities have implemented or are planning metro rail projects. Bus rapid transport systems are also being implemented or planned.

Between 2014 and 2017, ADB supported the construction and improvement of $1,483 \mathrm{~km}$ of national highways and $8,755 \mathrm{~km}$ of district and rural roads.
Transport is the largest component of ADB's sovereign portfolio in India, accounting for $41 \%$ - with roads taking a $92 \%$ share. In line with government priorities, ADB supports investment in national, state, district, and rural road connectivity, and institutional strengthening and capacity building. Its focus is on LIS and important economic corridors. ADB supports state road subsector projects, including rural roads, in 16 states. A subregional road connectivity project that ADB supports also seeks to improve the connectivity of India with Nepal, Bhutan, Bangladesh, and Myanmar. ADB's value-addition involves promoting safe and environmentally friendly practices, and elements of public-private partnership (PPP). Technical assistance has been extended to strengthen institutions and build the capacity of state executing agencies. The ADB transport portfolio also includes support for railways and a metro rail project in Jaipur.

ADB has supported the upgrade of state highways and major district roads for improving connectivity and access to economic opportunities as well as social services, institutional development, and capacity building (Box 2). Across states, ADB's largest lending in roads has been in Madhya Pradesh and Bihar. ADB has also provided support to the PMGSY since 2003. Its ongoing assistance comprises $\$ 800$ million for the Rural Connectivity Investment Program (Box 1) and $\$ 250$ million for tranche 1 of the Second Rural Connectivity Investment Program in five states.

\section{Box 1: Supporting Connectivity in Low-Income States in India through the Rural Connectivity Investment Program}

- The Rural Connectivity Investment Program (RCIP) supports Pradhan Mantri Gram Sadak Yojana, the national flagship scheme for expanding the rural road network, through an $\$ 800$ million financing facility and a technical assistance of $\$ 2.3$ million.

- The RCIP aims to improve connectivity of selected communities in 5 states by constructing about $9,000 \mathrm{~km}$ of all-weather roads by 2019, that will link about 4,200 habitations in Assam, Chhattisgarh, Madhya Pradesh, Odisha, and West Bengal. Of these, $7,000 \mathrm{~km}$ had been constructed by the end of 2017.

- The RCIP has also helped establish rural connectivity training and research centers and rural road network management units in each program state.

- Women comprise $30 \%$ to $40 \%$ of workers engaged in road construction and maintenance work across the five states.

Source: ADB. 


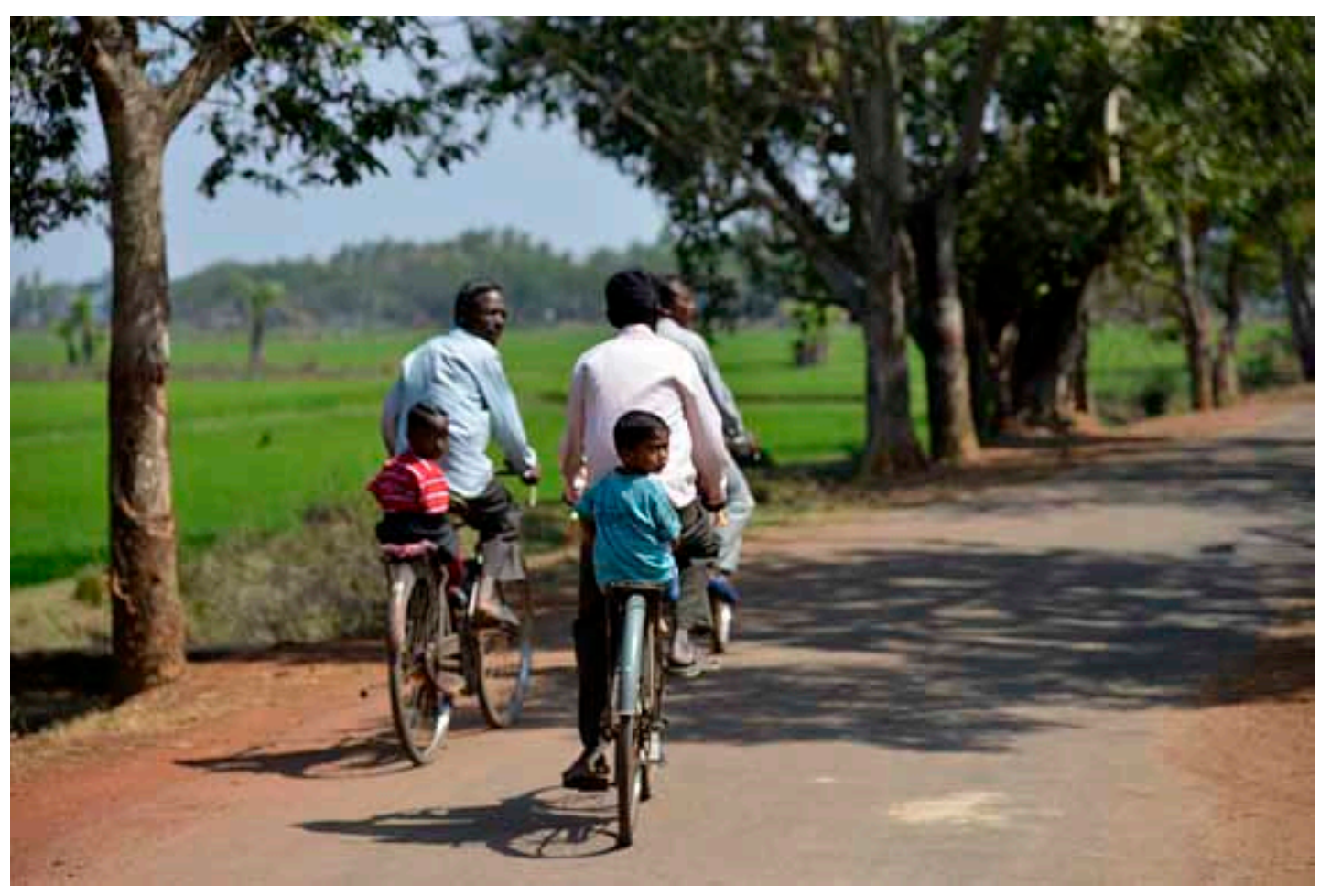

Expanding rural road network. Rural road constructed under the Rural Connectivity Investment Program (photo by ADB).

\subsubsection{Road to Opportunities: Bihar State Highway Project}

ADB has supported the Bihar State Highway Project through a loan of $\$ 351.5$ million for the rehabilitation and upgrading of $825 \mathrm{~km}$ state highways. This has improved the transport efficiency of the state road network, and boosted economic development and poverty reduction. Bihar State Road Development Corporation, a subsidiary agency of the Road Construction Department, Government of Bihar, was established and incorporated in April 2009. Its capacity has been strengthened in the areas of procurement, project management, contract management, road asset management, road safety, performance-based road maintenance, and private sector participation. The project has helped reduce accidents and travel costs and time. It has improved the rural poor's access to social services, healthcare, markets, and other economic activities and has provided substantial new work opportunities to local people.

ADB assistance for the road sector in Bihar has continued through two loans totaling $\$ 600$ million for rehabilitation of $643 \mathrm{~km}$ roads and another loan of $\$ 500$ million to construct a new $9.8 \mathrm{~km}$ sixlane bridge across River Ganga. When it is completed in 2021, the bridge will be the longest river bridge in India. ADB, through TA supported the Government of Bihar in the preparation of Road Master Plan for Bihar's State Highway Development.

Improved connectivity and increased traffic have helped establish new enterprises along the state highways in Bihar, creating employment opportunities for local people. 
Enhancing livelihoods. Ranjan Singh at his road-side eatery on $\mathrm{SH}-73$, near Masharak in Bihar (photo by ADB).

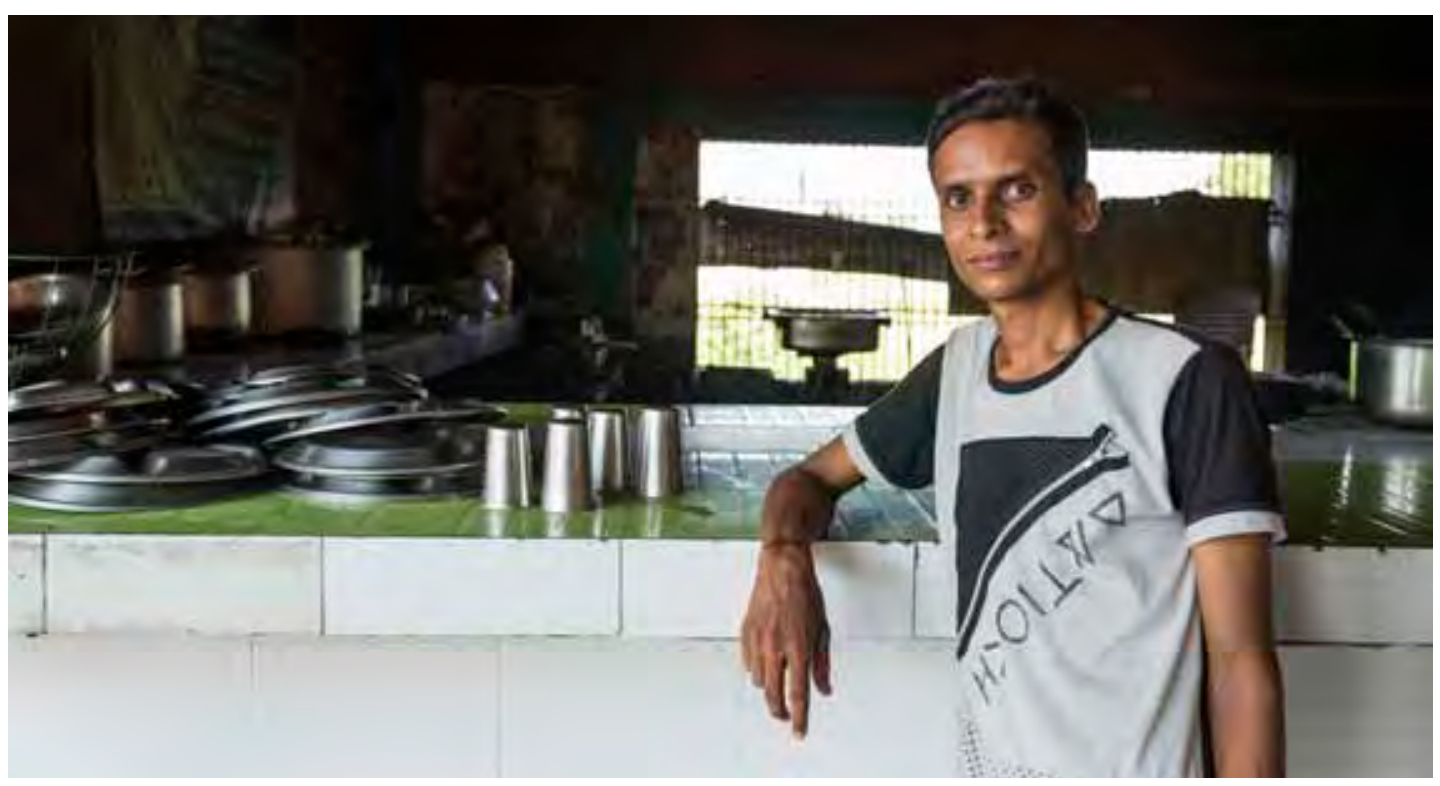

Until 2013, 26-year-old Ranjan Singh worked as a daily wage worker in Delhi, earning $\$ 2.50$ a day that was hardly enough to sustain himself in a big metropolitan city. Singh's parents, who lived in the native village Masharak in Bihar, convinced him to return home when the State Highway (SH-73) that passes through the village was upgraded as part of the ADB-funded project. They helped him set up a dhaba (roadside eatery) near the highway.

In 2 years, Singh's business flourished with the steady increase of commuters using the upgraded highway. "I am so happy with my decision to return to my village. It could not have been possible without the improved highway which has changed our fortunes," says the young entrepreneur. Singh now employs 12 workers at his restaurant.

Before development, the highway was in poor condition and notorious for thefts; it would take hours for police to reach victims. "The land here had no value. Now, with the improved state highway, our area is as good as gold," says Singh.

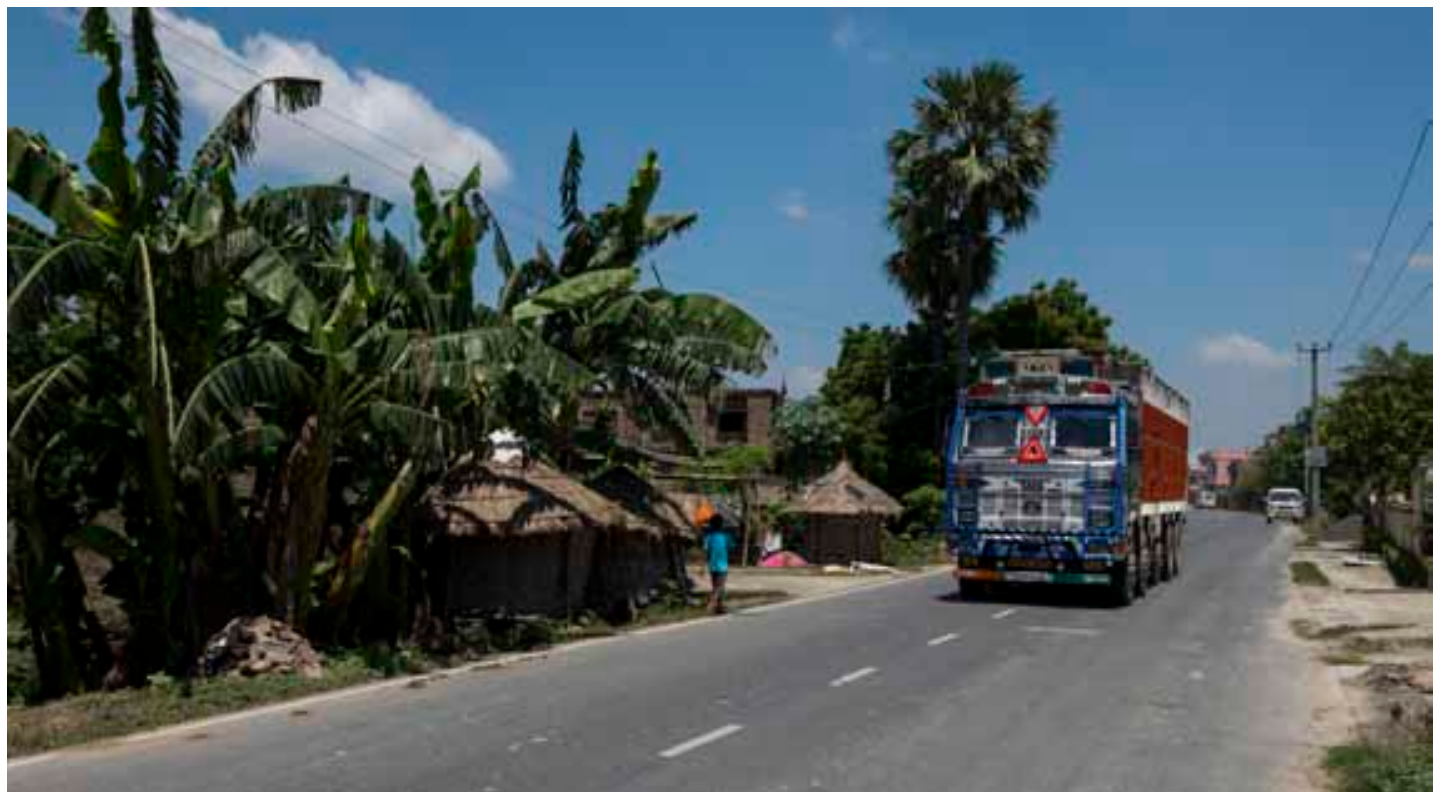


Lucky Sharma, an ironsmith, sells tools to farmers. Since SH-73 was upgraded, transporting raw materials from markets became easier and Sharma started getting more clients. He upgraded his business to cater to the construction industry that has helped him record a three-fold increase in his income.

\section{Box 2: Economic Development of Santhal Region and Improved Regional Connectivity: Jharkhand State Roads Project}

ADB has assisted the state of Jharkhand in the development of the 311-km Govindpur-Sahibganj state highway under the Jharkhand State Roads Project through a loan of $\$ 174$ million. The highway was completed in 2017, despite many challenges including greenfield alignment, law and order issues, and limited implementation capacity in the state.

The Govindpur-Sahibganj state highway improved transport connectivity in Santhal region, which is one of the least-developed but most resource-rich areas in Jharkhand. Connecting the Santhal region to the larger national and international highway network, this state highway is the main route to northeast India, reducing travel time by half-from 10 hours in the past. It is expected to accelerate the economic development of the Santhal people, expand economic opportunities, and reduce poverty.

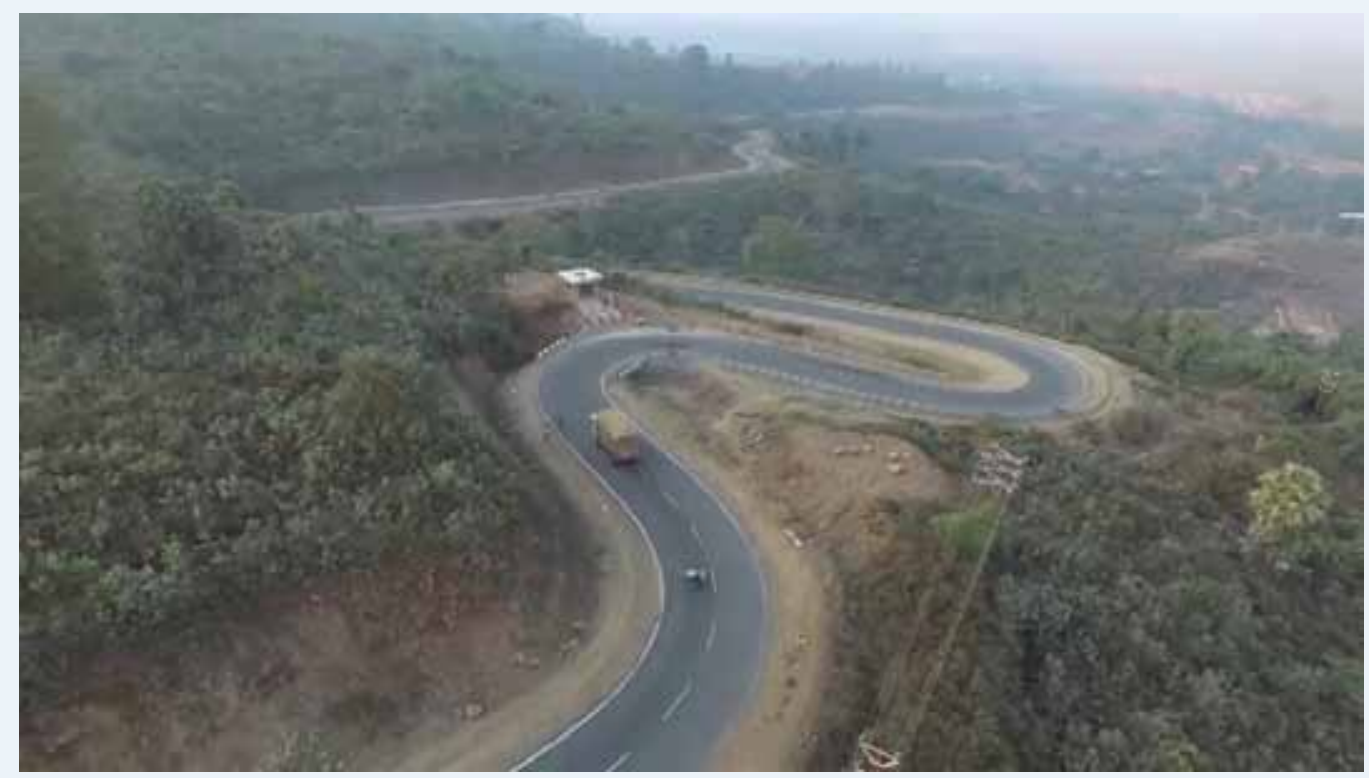

Linking remote regions. A section of the 311-km long state highway built under the ADB-supported Jharkhand State Roads Project (photo by ADB).

Local people appreciate the highway since they have faster and better access to facilities and economic opportunities. The project corridor has improved access to health and education, particularly for women. Many have setup wayside amenities (motels and restaurants), supplementing their income streams and improving their living standards.

Indeed, the Govindpur-Sahibganj state highway is not an ordinary road project, but a road to development and progress for the poor in Jharkhand.
The highway has a fenced avenue plantation comprising 476,800 trees-more than replacing the 20,868 trees felled to construct it.

\section{Rainwater harvesting structures have been provided every $500 \mathrm{~m}$ (where feasible) along the highway.}

Underpasses have been constructed to allow wildlife to cross the highway. 


\subsection{Urban Development: Fulfilling Aspirations}

According to the Census of India 2011, the country's urban population was 377 million, and is projected to grow to 600 million by 2031. Ensuring basic infrastructure and access to services, such as water supply and sanitation in urban areas, and improving the quality of such services, is a priority for the government. To achieve this and bring about urban transformation, key areas need to be addressed, including building the capacities of urban local bodies and utilities, strengthening revenue systems, and undertaking long-term urban planning. It is estimated that about $\$ 120$ billion will be required over the next 20 years for creating urban infrastructure to provide services, such as water supply, sewerage, solid waste management, and storm water drains (GOI, 2018a). The government's flagship Swachh Bharat or Clean India Mission (Urban), Smart Cities Mission for 100 priority cities, and Atal Mission for Rejuvenation and Urban Transformation for rejuvenating 500 cities aim to extend essential amenities with well-governed administration to invigorate urban transformation. ${ }^{5}$

The water and urban sector accounts for $19 \%$ of the ADB's ongoing sovereign portfolio in India. ADB's water and urban sector program is spread across 16 states, and focuses on water supply, wastewater management, drainage, solid waste management, tourism, and urban rejuvenation. Investments go beyond physical infrastructure creation, and support policy and institutional reforms, new technologies and instruments to establish and sustain $24 \times 7$ water supply systems, while reducing nonrevenue water, along with systematic capacity building. ADB's urban interventions also complement its evolving approach of supporting investments along economic corridors, by supporting township development, and detailed land use planning and land value capture-and enable urban local bodies to leverage grant funds, and also raise debt funds, in a fiscally prudent manner.

\subsubsection{Sufficient and Safe: $24 \times 7$ Water Supply in Ilkal under the North Karnataka Urban Sector Investment Program}

Water close at hand.

Students at a water treatment plant in

Ilkal, one of the first towns to achieve $24 \times 7$ water supply (photo by KUIDFC, Bengaluru).

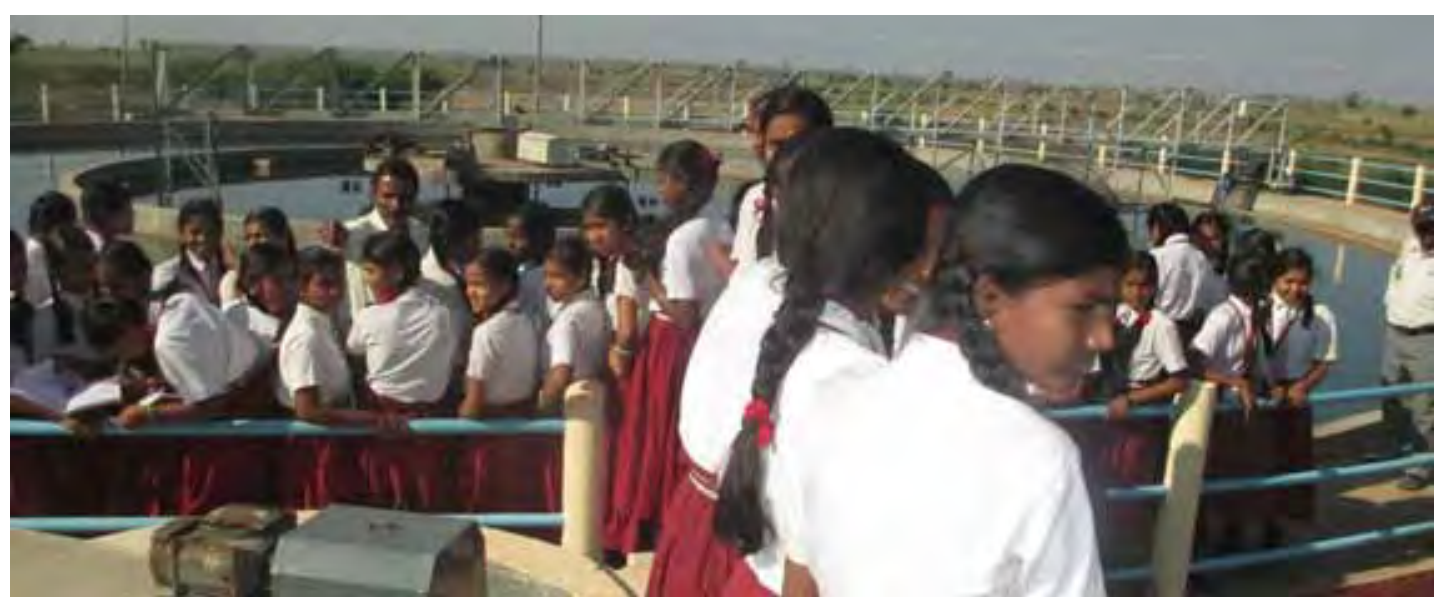

The ADB-supported North Karnataka Urban Sector Investment Program has been implemented by the Karnataka Urban Infrastructure Development and Finance Corporation. The $\$ 270$ million project provides improved water supply and sanitation services to nearly 4.3 million people across 25 urban local bodies. The program supplies $24 \times 7$ water to all residents and commercial and service establishments in Ilkal. Known for its exquisite hand-woven silk sarees, Ilkal is home to over 50,000 people. It falls in a semi-arid zone and faces natural scarcity of water.

5 GOI, Ministry of Housing and Urban Affairs. Swachh Bharat Urban. https://swachhbharaturban.gov.in/; GOI, Ministry of Housing and Urban Affairs. Smart Cities Mission. http://smartcities.gov.in/content; and GOI, Ministry of Housing and Urban Affairs. Atal Mission for Rejuvenation and Urban Transformation. http://amrut.gov.in. 


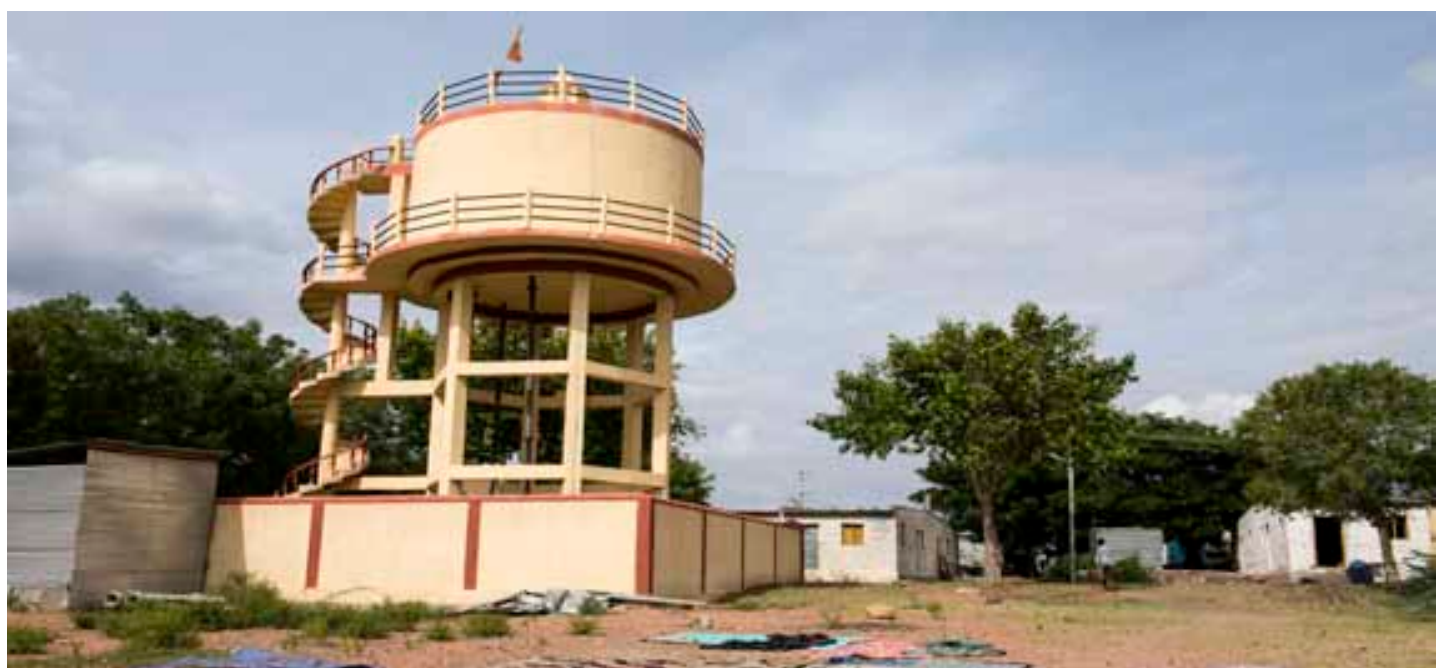

Shankaramma's face lights up at the mention of $24 \times 7$ water supply project. Shankaramma lives in Durga Devi Nagar, a low-income settlement in Ilkal town. She works as a cook. Earlier, fetching water was an arduous and time-consuming task for Shankaramma. She was often reprimanded for being late at work.

Before the project, the water supply situation in Ilkal was poor. The water supply of 2-4 hours per week was irregular, insufficient, and unsafe. Only half of the households had house service connections (with a bare minimum supply).

Schools and hospitals had to buy water from private suppliers to ensure regular availability. Most people suffered from fluorosis due to the high fluoride content of the supply water. ${ }^{6}$ Prevalence of skin and water-borne diseases was also high.

Residents of the Nekar (weaver) colony share this experience. For the 250 weaver families, the nearest water supply point was $3 \mathrm{~km}$ away. Each household would spend 3-4 hours every day collecting and storing water. This meant a loss of about $\$ 2$ per day for a weaver couple, who would have earned this amount working on the loom. Now, each family spends $\$ 1$ per month and receives uninterrupted $24 \times 7$ water at their doorstep. The time saved is now used for weaving. Children attend school regularly and the burden on women has been significantly reduced.

ADB supported the development of a water distribution system, house service connections, additional sump, and fire hydrants. It also helped to generate community awareness. Rather than adopting a conventional approach of focusing on capital investments, the program emphasized suitable service delivery, bringing private sector efficiency to the operation and management of the water supply schemes. Community participation created awareness of the project and built consensus on meters and volumetric tariffs.

ADB assistance enabled Ilkal to become one of the first towns in India to achieve 100\% coverage of $24 \times 7$ water supply (Box 3 ). The project demonstrated that this could be achieved in developing countries, while also highlighting the importance of both technical and social components for the success of the project.
Water supply infrastructure. Overhead water tank constructed as part of North Karnataka Urban Sector Investment Project (photo by ADB).
“Earlier, fights would break out among neighbours at the water supply point. Now that every family has its own tap, we live like civilized people."

Haider Bibi, 40, Durga Devi Nagar, Ilkal

\section{"Before the new water supply system, our children used to miss school on supply days because fetching and storing water was the foremost priority. Thanks to the project, we live a normal life." \\ Rajma Bibi, 32, Nekar Colony, Ilkal}

\footnotetext{
${ }^{6}$ Fluorosis is a debilitating disease that damages bones and teeth, often causing crippling pain.
} 
Earlier scenario. Long queues at public water points in llkal before the $24 \times 7$ water supply became a reality (photo by ADB).

Current scenario. Rajma Biwi is one of the weavers at Nekar in Ilkal, who benefited from the $24 \times 7$ water supply project (photo by ADB).
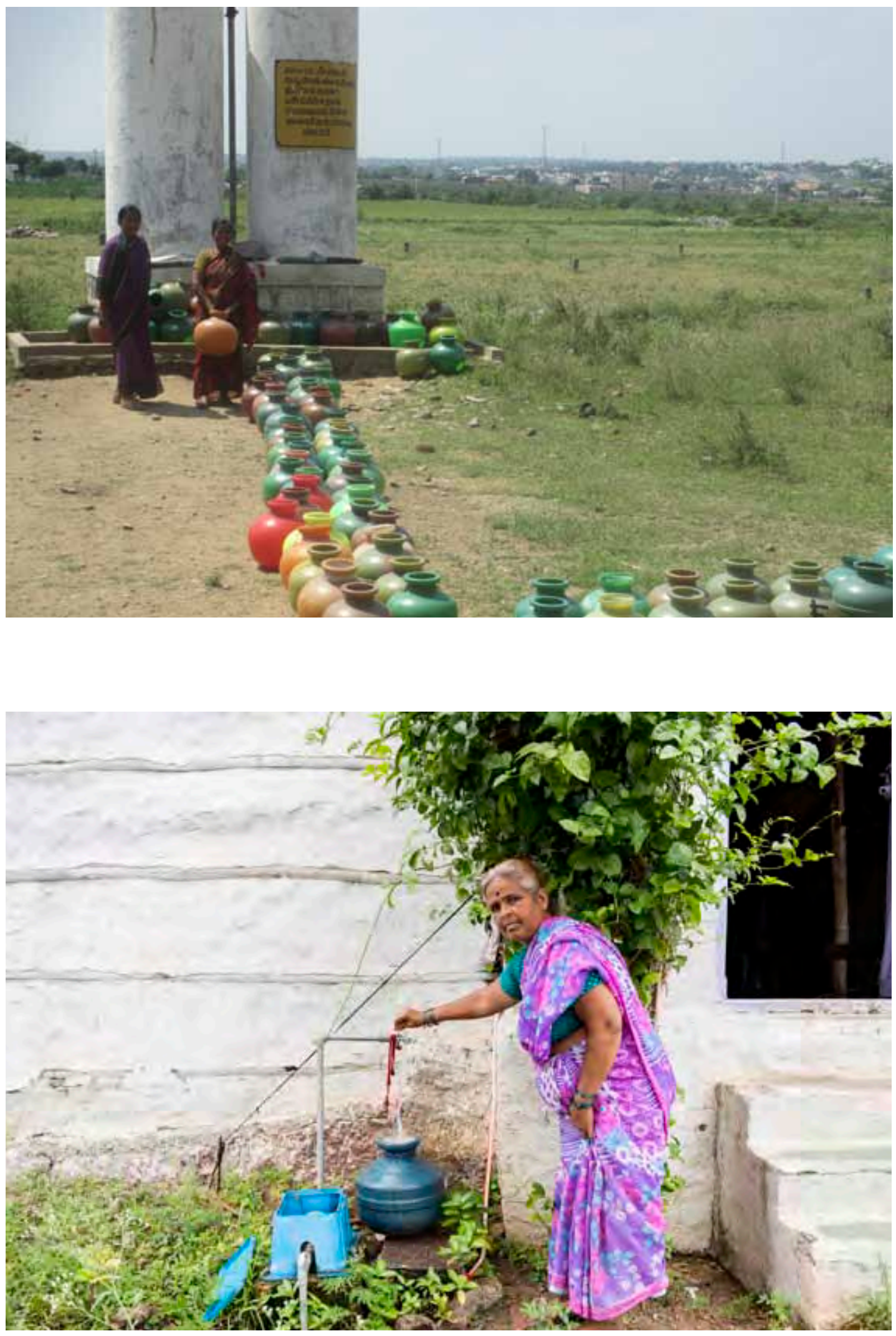
Part of the success of the project is attributed to the innovative "performance-based construct and operate contract," which facilitated PPP. The model worked well for Ilkal because the contractor responsible for construction was also responsible for operation and maintenance (O\&M). Remuneration was partly based on performance, monitored by an independent technical auditor during the O\&M phase. This ensured consistently satisfactory service delivery to the customers.

\section{Box 3: Key Achievements of the 24x7 Water Supply Project, Ilkal}

\section{Physical output}

- Over 10,000 houses and commercial establishments receive $24 \times 7$ water supply.

- All connections are fitted with volumetric meters.

- The water supply is projected to be sufficient for next 30 years.

\section{Benefits to the community}

- Regular supply of safe water at the doorstep is assured.

- Families are able to spend more time on productive activities.

- Schools, hospitals, and commercial ventures make substantial savings.

- There has been a decline in cases of fluorosis.

\section{Gender equality results}

- Time saving for women due to alleviated water collection.

- Improved health and hygiene for women.

\section{Capacity building}

- Implementing agencies learned about new technologies in water supply and distribution.

- The customer care center is strengthening local capacity to manage water supply services. This helps to increase the customer interface and facilitates improved water tariff collection.

- The capacity of urban local body representatives to plan and oversee development projects has increased.

Source: ADB.

Implementing the project was not straightforward. Raising community support required sustained stakeholder consultations and partnerships with community-based organizations. The efforts were worthwhile, however, and the project received immense public support as the improvement in the quality of life became palpable. Enhanced availability and quality of water not only freed up time to pursue livelihood activities, but also contributed to better health outcomes, as evidenced by a significant decline in cases of fluorosis and water-borne diseases treated by the Ilkal Community Health Center. 


\subsubsection{Preserving the Environment and Heritage with Communities: Infrastructure Development Investment Program for Tourism}

"We realized that our village will get a special mention on the country's map and it will generate

a new wave of economic activity in our area. We are now very proud of our community reserve."

Prithvi Raj, 65, elected representative, Keshopur Chhamb

Bird corridor. Migratory birds flocking at the Keshopur

Chhamb Community Reserve (photo by PHTPB, Punjab).
$A D B$ is helping India realize its tourism potential to contribute to sustainable and inclusive economic growth. The ADB-supported Infrastructure Development Investment Program for Tourism has helped upgrade tourism infrastructure, promote community-based tourism-related economic and livelihood activities, and drive ecotourism development across Himachal Pradesh, Punjab, Tamil Nadu, and Uttarakhand.

Each tranche of the program has a gender action plan (Box 4) that provides a guide for genderresponsive project implementation and includes specific gender-related activities and targets. A successful initiative in community involvement for developing a freshwater ecosystem-Keshopur Chhamb Community Reserve (KCCR) - was created under the project in Gurdaspur district of Punjab under tranche 1 of the investment program.

Spread over 344 hectares of community land across five villages, the Keshopur Chhamb Community Reserve is an important waterfowl habitat and migratory bird corridor. Over the past decade, the water bodies became infested with water hyacinth that led to a significant decline in the number of birds visiting the reserve. Rehabilitation and conservation of the wetlands was undertaken as part of the program. The implementing agency, Punjab Heritage and Tourism Promotion Board, involved the Forest Department and the local communities in conservation efforts.

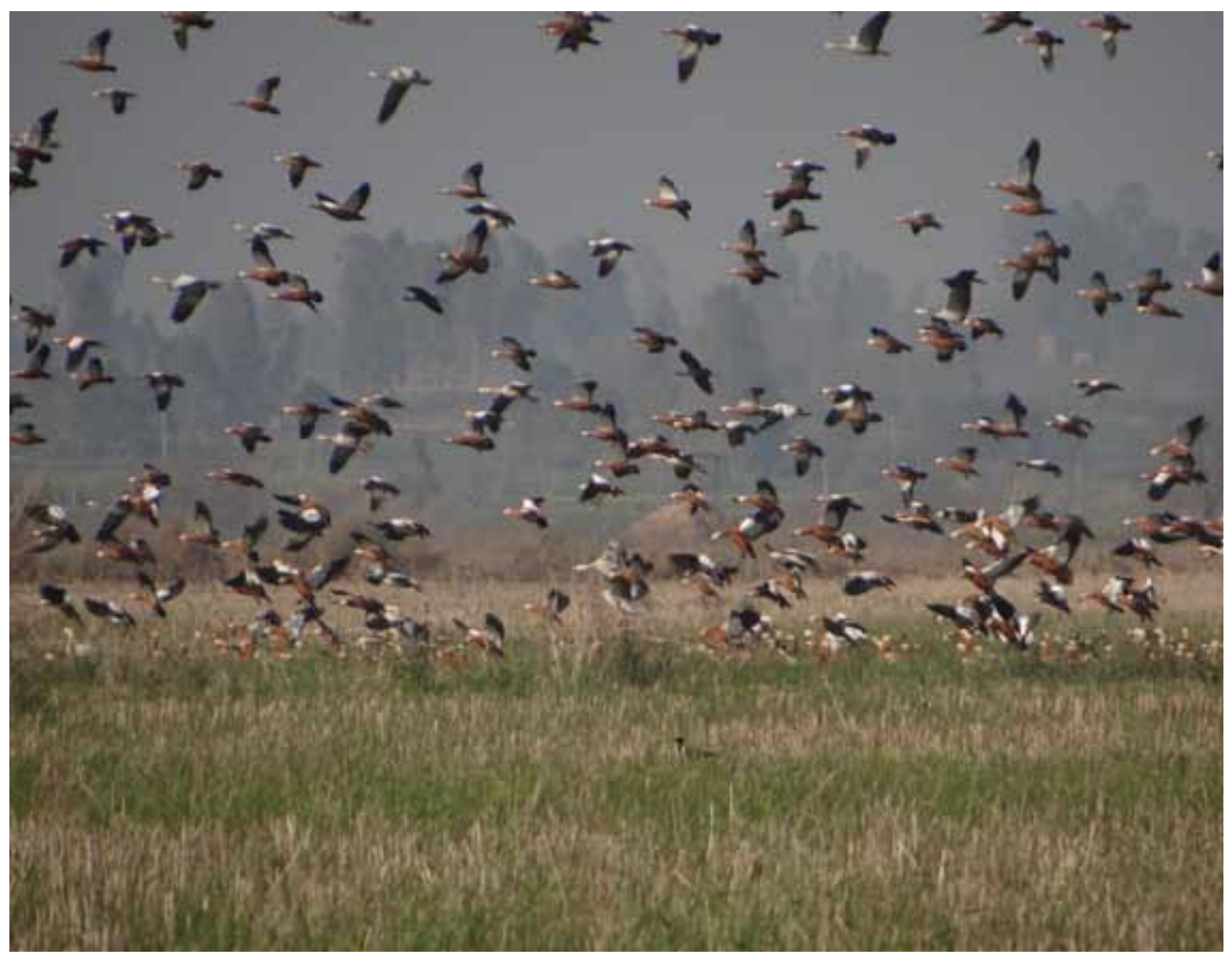




\section{Box 4: Walking the Talk: Gender Action Plan in Keshopur Chhamb}

Women's representation and participation was ensured in awareness building and consultation processes, and the activities were planned with consideration of women's availability and convenience.

- Women representatives were included in the citizen forums that were tasked with the responsibility of preparing the master plans and comprehensive mobility plans.

- Under the community-based tourism model, women representatives of the Panchayat Tourism Development Committee and self-help group (SHG) members were consulted in planning activities and selecting products to be developed.

- About 15 SHGs were formed in Keshopur Chhamb, with a total membership of 172, including 164 women as of December 2017.

» The groups were linked to formal banks for savings and loans.

» SHG members were trained in utilizing water hyacinth, an otherwise waste material, in a variety of products, such as quilts and bags, jute baskets, fabric, and food products.

- Women participate in exhibitions organized by departments of rural development and tourism. They also get repeat orders from people who have tried their products.

"Our group received training for making products of water hyacinth fiber. We sold products worth $₹ 77,000$ (about \$1250) last year.” Ms Renu, village head, Miyani, Keshopur

Source: ADB.

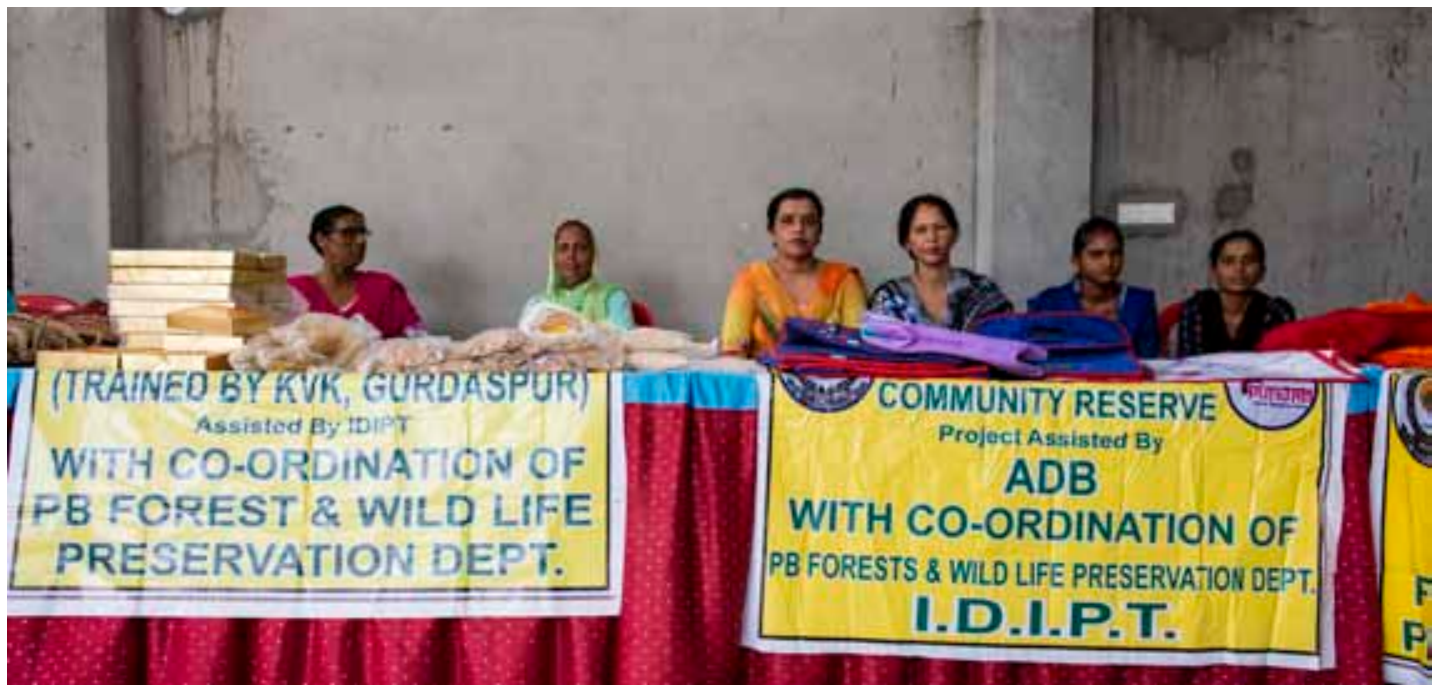

Local leadership stopped farming in the reserve. Authorities also cleared the area of water hyacinth and established bird watching trails. SHGs, formed under the project, were trained in incomegenerating activities. Young people were trained as nature guides. Once the village communities were engaged, the results were quick to come. Between 2012 and 2016, the count of migratory birds visiting Keshopur Chhamb increased from 4,581 to 25,203. In terms of economic benefit, the village panchayat (local governance) made an income of nearly $\$ 16,000$ in FY2016 by selling lotus stems and trapa, an aquatic plant that grew in the reserve area.
Supporting livelihood opportunities.

Women beneficiaries of the Infrastructure Development Investment Program for Tourism (photo by ADB).
“ADB's project helped create corecompetence within the department and provided the flexibility to hire need-based expertise." 


\subsection{Energy: Brighter Prospects}

India achieved a significant milestone in April 2018 by bringing electricity to all the 597,464 census villages in the country. Building on this impressive first step, the government has launched the Soubhagya program to achieve 100\% household electrification by March 2019. To meet its even more ambitious goal of $24 \times 7$ electricity for all, India recognizes the need to increase electricity generation capacity, streamline transmission network with improved interstate connectivity, and restore financial sustainability and operational performance of distribution. India is also working toward achieving a target of $175 \mathrm{GW}$ of installed renewable energy capacity by 2022 (GOI, 2017b). India places emphasis on achieving end-use energy efficiency and reducing carbon intensity in the energy sector.

\section{Box 5: ADB Support to India's Power Sector}

Energy is one of the leading sectors of ADB assistance to India. From 1986 to 2017, ADB has committed 59 sovereign loans to the energy sector amounting to $\$ 9.98$ billion.

The current energy portfolio (December 2017) includes 21 loans amounting to $\$ 3.46$ billion. ADB is supporting investments in power transmission by central agencies such as the Power Grid Corporation of India for inter- and intra-state transmission network investments by the states of Assam, Bihar, Himachal Pradesh, Rajasthan, and Madhya Pradesh. The distribution network is being upgraded through ADB support in Madhya Pradesh and Assam.

In the conventional power generation sector, ADB is supporting hydropower plants in Himachal Pradesh. Two projects involve large-scale renewable energy and installation of solar roof tops, and another project is promoting end-user energy efficiency.

Source: ADB.

Energy constitutes $27 \%$ of ADB's active sovereign portfolio. ADB interventions in energy sector focus on electricity transmission, distribution, and generation, with emphasis on renewable energy sources and end-user energy efficiency. (Box 5).

ADB works closely with state power utilities to strengthen transmission and distribution networks, and implement smart metering, feeder separation, and high-voltage distribution systems. At the national level, ADB has supported a series of interventions to strengthen the national grid, and establish a "green energy corridor" to facilitate integration of renewable energy into the national grid. Further, $A D B$ is promoting regional power transmission interconnections with neighboring countries. $A D B$ also supports private investment in renewable energy generation through dedicated credit lines for grid integrated renewables and solar roof tops. End-user energy efficiency improvement is promoted by supporting investments in efficient water pumps, and LED and solar street lights. ADB has also provided advisory and capacity development support through TA grants to the center and the states. ${ }^{8}$

ADB's intervention in supporting evacuation of power from one of India's pioneering solar parks in the state of Gujarat also demonstrated a successful model of PPPs in energy.

\footnotetext{
7 Rural Electrification Corporation Limited. Scheme of Government of India for Rural Electrification. http://www.ddugjy.gov. in/portal/index.jsp (accessed 16 May 2018).

8 Part of the support of ADB to renewable energy in India is also implemented through its Private Sector Operations Department (PSOD).
} 


\subsubsection{Tapping the Sun: Gujarat Solar Power Transmission Project}

ADB partnered with the Government of Gujarat to develop the first solar park in India at Charanka. It provided a $\$ 75$ million loan during 2011-2016. The project was executed by the Gujarat Energy Transmission Corporation Limited (GETCO). ADB assistance focused on setting up the transmission network of underground power cables, substations, and lines for efficient evacuation of power, and supporting local communities for economic development through technical assistance.

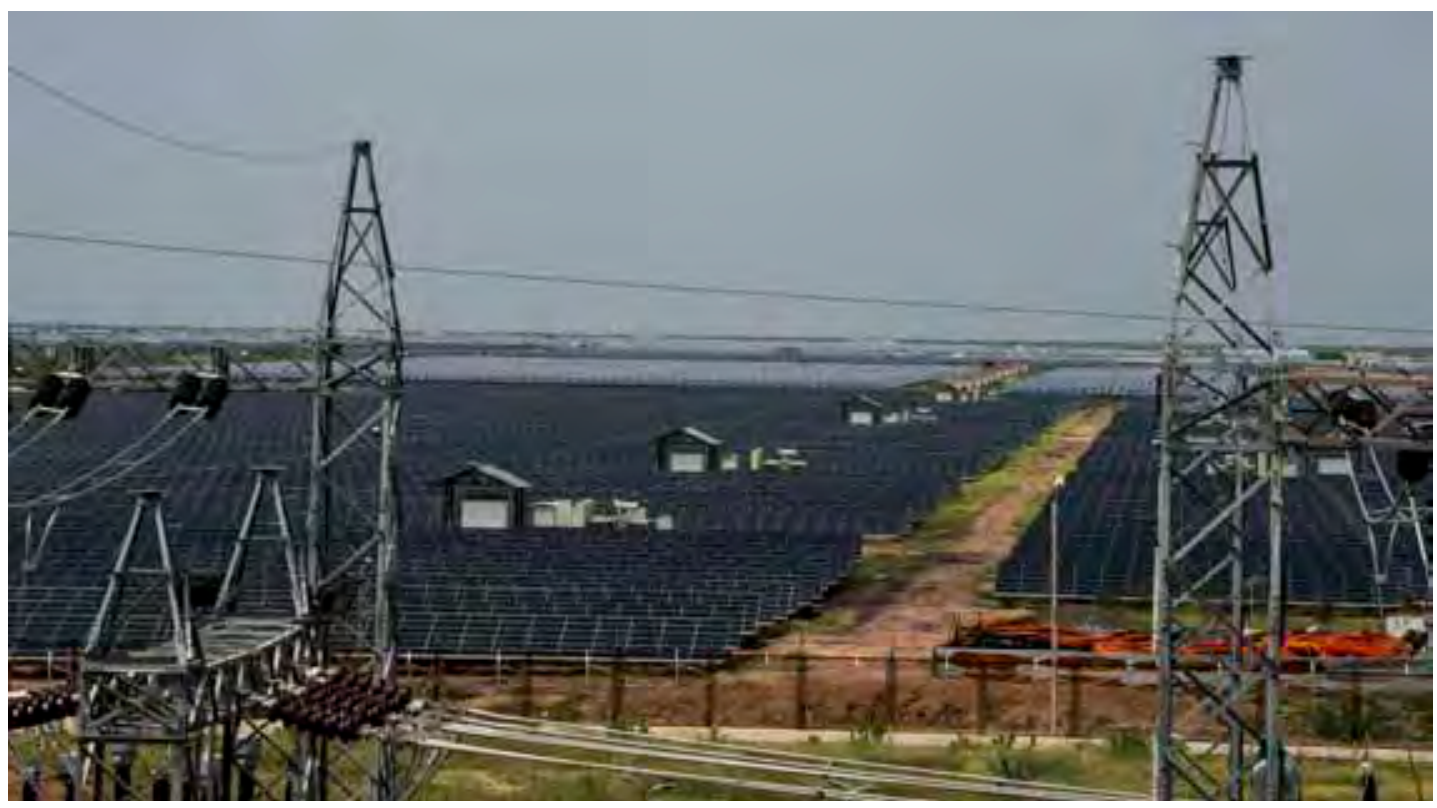

"The focus of GETCO was to develop a highly reliable solar power evacuation network and minimize power losses during transmission. ADB support greatly contributed to this component."

M K Jani, GETCO official

\section{Renewable power evacuation. A power sub-station built at the Charanka Solar Park as part of an ADB-supported project (photo by ADB).}

Spread over 2,179 ha, the Charanka Solar Park in Patan district of Gujarat is one of the largest solar parks in Asia. The current generation capacity of the park is $503 \mathrm{MW}$, with a potential capacity of $650 \mathrm{MW}(\mathrm{ADB}, 2013)$. About 29 private developers are currently operating generation units, with varying capacities, ranging from $1 \mathrm{MW}$ to $25 \mathrm{MW}$. When fully developed, the park is expected to reduce carbon dioxide emissions by 5.2 million tons and save 900,000 tons of natural gas annually (Box 6).

\section{Box 6: Key Results: Charanka Solar Park}

- Key outputs included construction of a substation comprising two 315 megavolt amperes (MVA); 1 MVA bus reactor, eight 100 MVA transformers and $137 \mathrm{~km}$ of underground cable grid within the park, and $219 \mathrm{~km}$ double circuit transmission line from the park to villages

- Key achievements included minimized transmission losses of solar power, successful demonstration of PPP in solar energy production, and support for the local community in economic development including training for rural women in mobile repairs, energy conservation, kitchen gardening, and smokeless stoves. 
"A few years ago, this was barren

land with no

facilities. Now you can see several

pucca houses and all villagers get safe potable water."

Dala Bhai Ahir, 32 yrs, employed in Charanka Solar Park

Benefiting local communities. Jayesh Parmar and Bhargawa Darji, (extreme left; both 24) obtained electrical diplomas from a local technical training institute and worked as switchboard operators in a solar power plant outside the village. As the Charanka Park was developed, both returned to their village and now work at the park (photo by ADB).
The Charanka Solar Park was one of the first solar parks conceptualized in India. It successfully demonstrated the advantages of a public-private partnership. While the public sector supported the required land clearances, site development, and creation of common infrastructure, the private sector focused on financing solar photovoltaics on a plug and play basis. This reduced the cost and time for solar photovoltaic development. This solar park demonstrated large-scale development of reliable solar power projects in a cost-effective manner.

$\mathrm{ADB}$ assistance in this project enabled GETCO to acquire the necessary expertise and increase investors' confidence in this new initiative. ADB support was essential to ensuring quality infrastructure. Transmission lines were laid underground, so that their shadows would not reduce their efficiency.

The solar park was developed entirely on wasteland, and brought several benefits to local communities. Approach roads built under the project, supply of safe drinking water, improved schools, and a health center within the park improved the quality of life in the vicinity of the solar park. ${ }^{9}$

The Narmada Canal built by the state government is the main source of water for the solar park and neighboring villages. The park is also equipped with a rainwater harvesting system. Furthermore, an old pond has been rehabilitated to provide water for cleaning the solar panels.

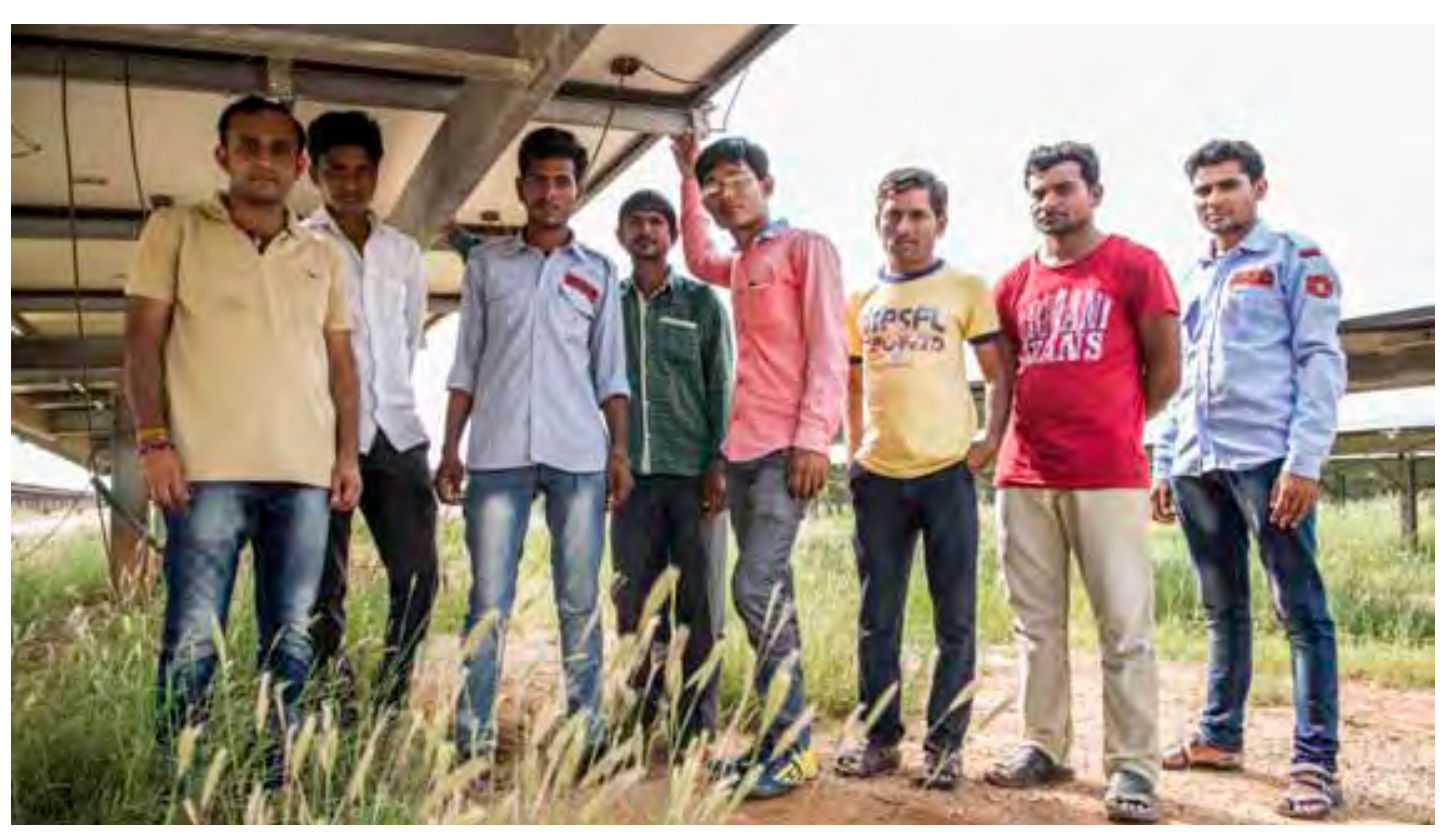

Over 700 local people are currently employed by the developers in the solar park. Several young men, earlier compelled to go in search of work in other cities due to lack of local employment opportunities, have returned to work here. The opportunities created by the park are inspiring local youth to undertake technical training through industrial training institutes.

\footnotetext{
9 The school and health center are supported under the corporate social responsibility initiative of Gujarat Energy Transmission Corporation Limited.
} 


\subsection{Agriculture and Natural Resources: Prosperity for Posterity}

The Government of India aims to boost agricultural productivity and guarantee income security for farmers by doubling their income between 2016 and 2022 (GOI, 2017c). The government considers agriculture as an enterprise and wants to help farmers produce more from the same land parcel at lesser cost and simultaneously realize higher prices for their produce (GOI, 2018c). Key priorities of the government include boosting agricultural productivity with a focus on irrigation, seeds, fertilizer, and technology, along with a shift to high-value farm products. It also intends to reform the fragmented agricultural market.

Agriculture and natural resources constitute a small share (3\%) of ADB's ongoing portfolio in India but support critical areas. These include adopting newer technologies of pressurized distribution network to improve irrigation water use efficiencies, incorporating climate change adaptation into project design, and modernizing irrigation and flood control structures for better water management. Projects for agriculture and natural resources include the development of infrastructure for irrigation, protection from floods and river and coastal erosion, and river basin management.

\subsubsection{Saving Coasts, Protecting Lives: Sustainable Coastal Protection and Management Investment Program, Tranche 1, Karnataka}

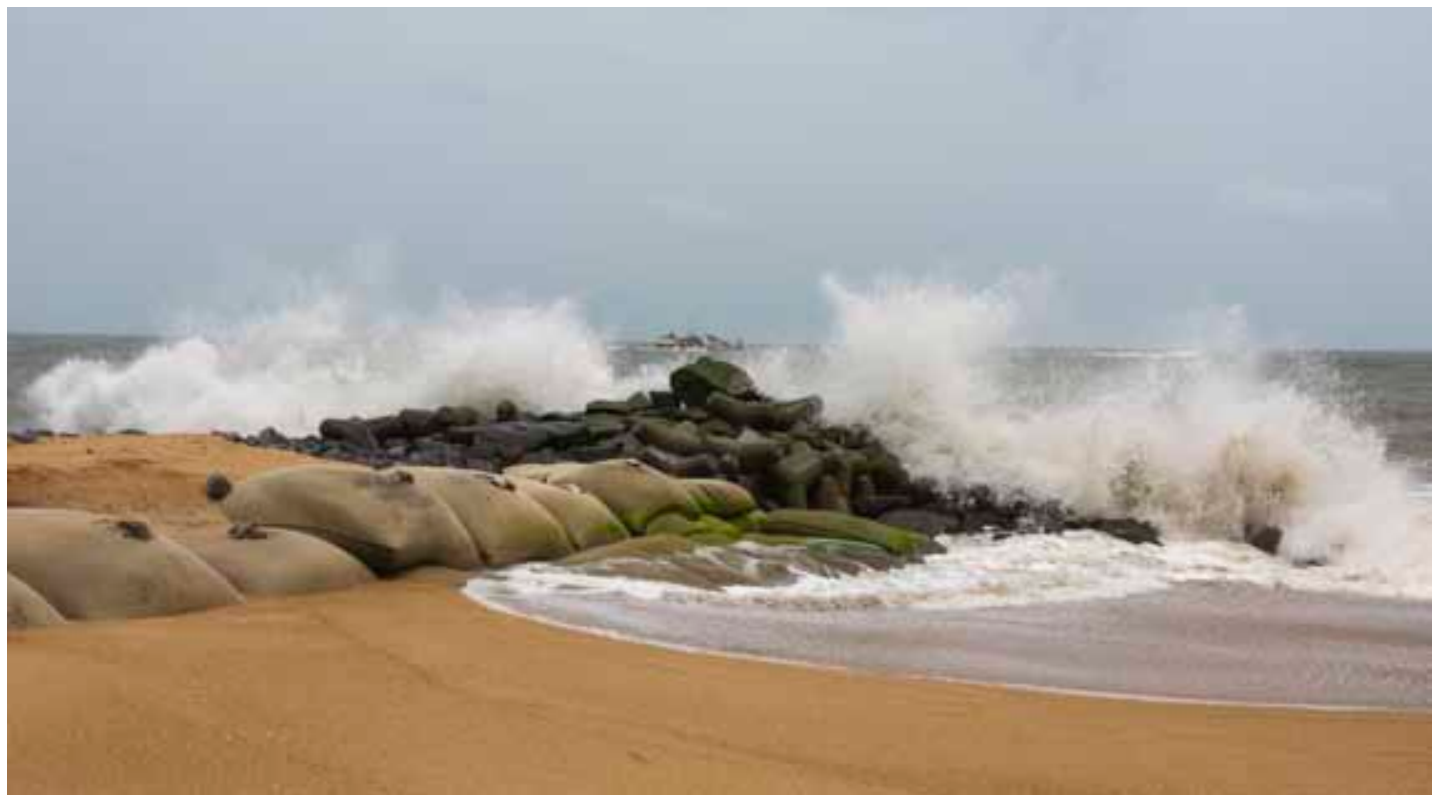

The Sustainable Coastal Protection and Management Investment Program was implemented between 2012 and 2017 with a loan of $\$ 41$ million for the first tranche. The project adopted a holistic approach, bringing offshore coastal protection structures to contain erosion; using eco-friendly construction materials, such as geotextile bags; increasing community participation in beach management; and building the capacity of state agencies to meet the long-term needs of sustainable coastal protection and management. The project has contributed to significant coastal protection and management in India, and initiated a new approach of participatory planning and integrated development of environmentally and socially appropriate coastal protection solutions, with the transfer of knowledge to a wider community.
Beach protection. Construction of berms under the Sustainable Coastal Protection and Management Investment Program, Ullal, Karnataka, has reclaimed the beach and protected the assets of fishing communities (photo by $A D B)$. 
Feeling protected. Jalajeshwari Suvarna, 55 , a resident of Ullal village in Karnataka (photo by ADB).

"My house would have submerged in the sea by now had the breakwaters and berms not been constructed under the project."

Jalajeshwari Suvarna, 55, resident of Ullal village

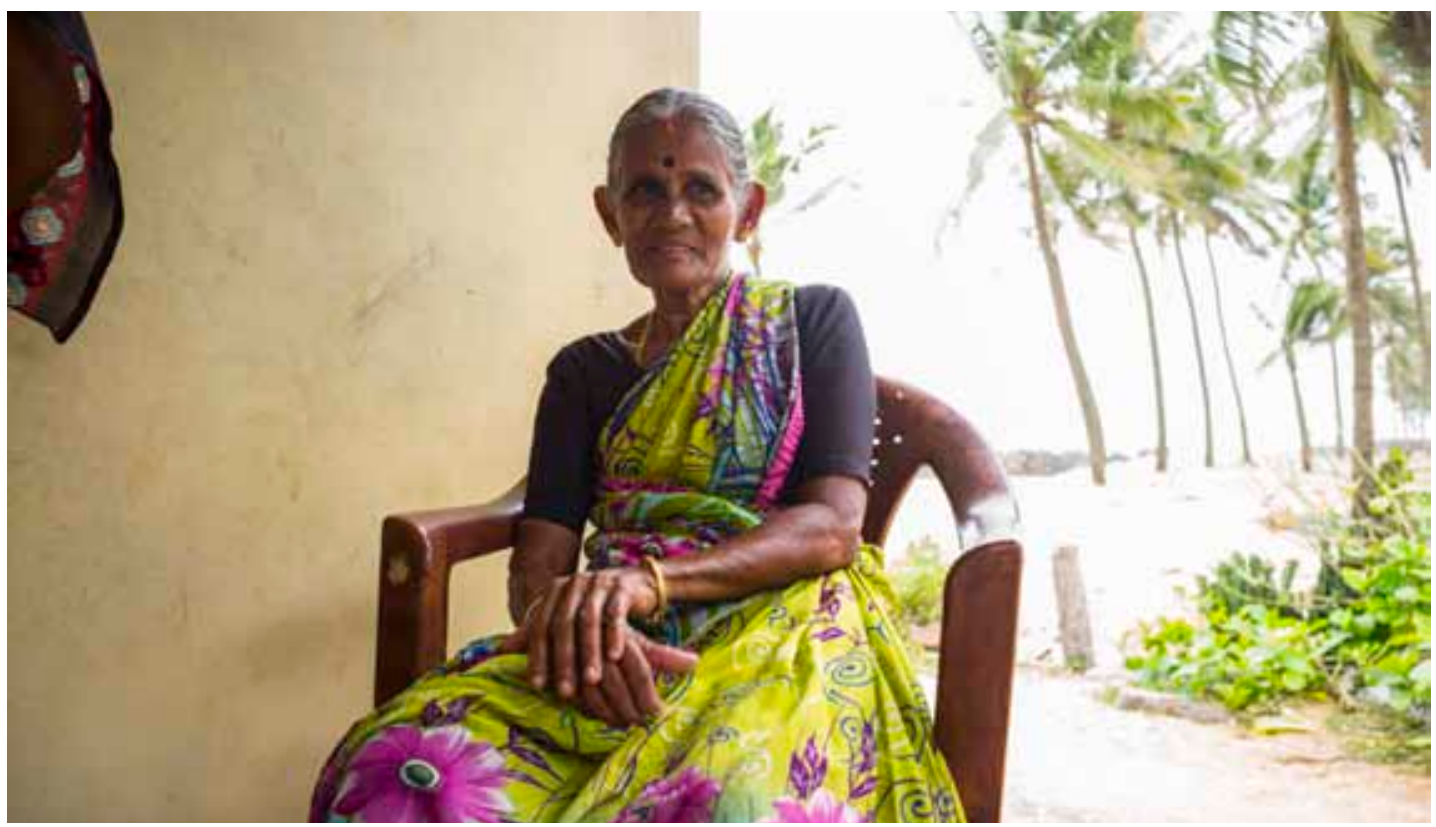

Ullal village, in the state of Karnataka on the southwest coast of India, has been slowly eroding since the construction of two breakwaters in 1994. Coastal protection measures adopted in 1996 included rock seawalls, gabions, and sand-filled plastic bags tested at many places along the coast. But all these initial measures were destroyed by waves and, a decade later, the waves touched the settlements. This led to several programs to identify the causes and address the erosion at Ullal. Fish drying, a work primarily undertaken by women was edged out due to lack of space. Families living along the coastline were worried about their assets and livelihood.

Based on modern design approaches and participatory planning, the ADB-supported shoreline protection project has contributed to stabilizing the coastline. The reefs that were built are larger and further offshore than any previous offshore protection structures in India. The innovative design has stabilized the coast over a distance much greater than the reef length. The shoreline infrastructure proved resilient and minimized damage in the region during Cyclone Ockhi, which hit southern India in December 2017. The project exposed the State Port Department to new and effective technologies in sustainable coastal erosion management, and enhanced its technical and managerial capacity for similar future projects.

The project has checked the erosion and restored beaches in Ullal and Bengre villages. Beach width has significantly increased from between $7 \mathrm{~m}$ and $10 \mathrm{~m}$ up to as much as $70 \mathrm{~m}$ in some areas. The communities living on the Ullal coastline are less vulnerable, and more confident in the safety of their assets and livelihoods. In addition, as an incidental benefit, reefs are serving as breeding grounds for marine animals, and fisherfolk around the reef area note a significant increase in their catch per trip. Increased income from the fish has also reduced their dependence on debt during leaner seasons.

The benefits of the project are not limited to fisherfolk. With the development of beaches, tourists have started visiting Ullal in increasing numbers. This has encouraged the local communities, including women, to start small shops along the beach to serve tourists and to organize beach festivals. 

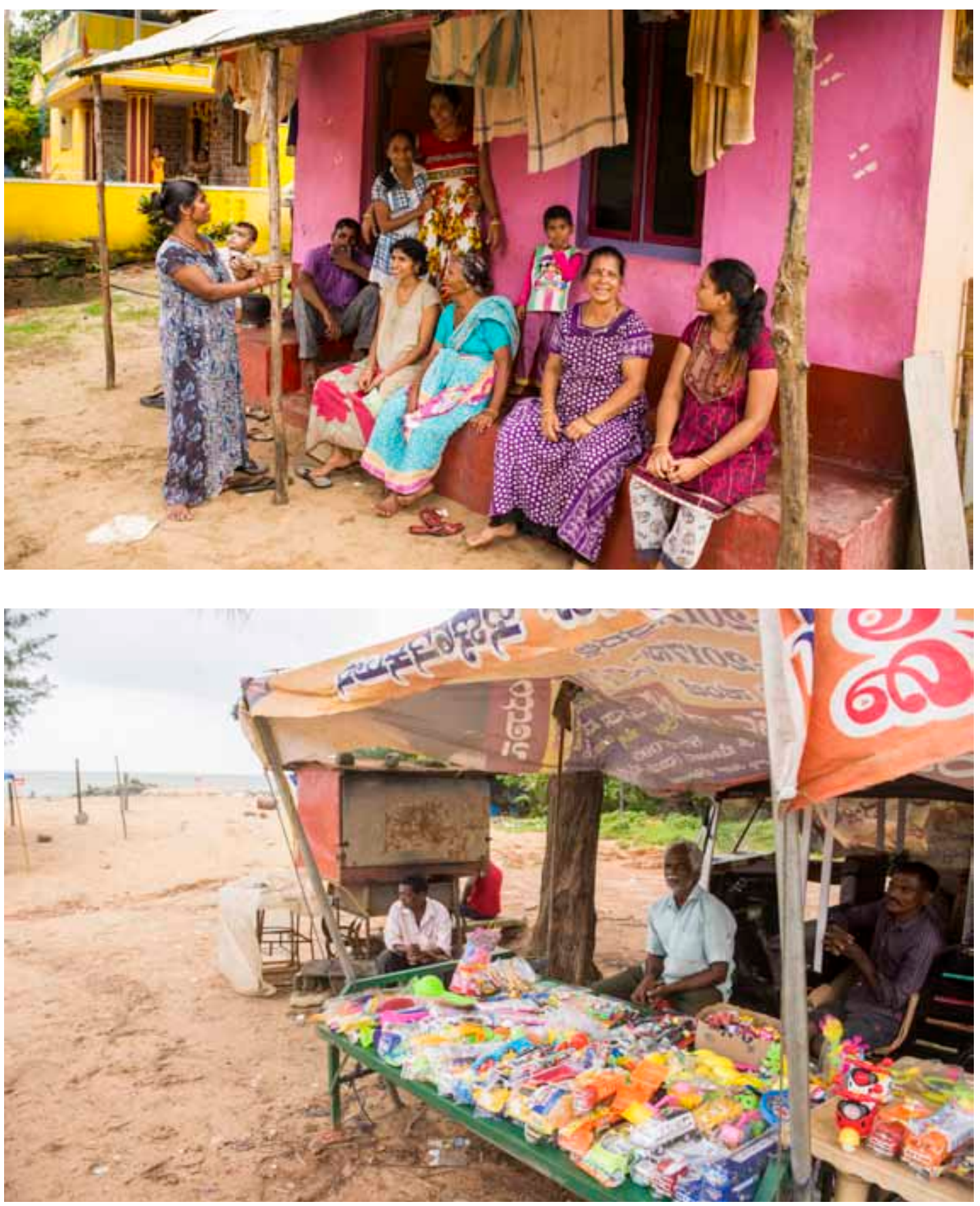

Communities at ease.

Fishers in Bengre seem to be relieved after breakwater construction under the Sustainable Coastal Protection and Management Investment Program (photo by ADB).
Serving tourists.

Arvind Daksha, 49, a former wage worker now runs a toy shop at Ullal beach. His earning has almost doubled following the beach reclamation under the Sustainable Coastal Protection and Management Investment Program (photo by ADB).

Shoreline management organizations, representing local communities and leaders, were formed in both Ullal and Bengre villages. They have raised awareness on coastal erosion, common property management, and maintenance of beaches. The organizations are actively undertaking beach development activities such as cleaning, lighting, and providing lifeguard facilities and community services. 


\subsection{Human Development: Investing for the Future}

Having achieved the goal of universal primary education, India is now focusing on enhancing learning outcomes at all levels of education. Use of information and communication technology in teaching and learning, introduction of learning-centric evaluation systems, and greater focus on employabilityled education are key measures taken by the government (GOI, 2017b). Skill development for better alignment of demand and supply of a skilled workforce is the main priority of the government. Under the flagship Skill India Mission, tens of millions of people will be equipped with industry-relevant, employable skills by 2022, and to play an instrumental role in supporting other programs promoting industry-led development and entrepreneurship.

India has made significant progress in health outcomes over the last 2 decades, but on certain key indicators, lags behind other countries at similar stages of development and levels of spending on health. Rethinking its long-standing strategies, India is emphasizing delivery of public healthcare services with a shift in focus from curative to preventive care (GOI, 2017b).

ADB operations in the human development sector in India started in 2012, and are still at an early stage, focusing on applying good practices in Asia and the Pacific, adapting to local conditions, and demonstrating high value addition. ADB's skills development interventions will continue to support technical and vocational education and training to improve the employability and productivity of the growing workforce in line with emerging and future industrial demands. They will also strengthen the skills ecosystem by reinforcing national priorities and introducing international benchmarking. ADB will add value to the government's skills development efforts by addressing unique development needs of states; adopting an industrial cluster approach; promoting job-ready skills acquisition; integrating soft skills into broader technical and school education; introducing international standards for benchmarking and facilitating partnerships; leveraging engagement with private players; and strengthening institutional capacity for technical and vocational training and the monitoring and evaluation framework.

ADB's human development program also supports the government's efforts to improve the health of people who live in cities, especially the poor and vulnerable, under the National Urban Health Mission. Key areas of ADB support include strengthening the urban primary healthcare delivery system; improving the quality of services; and strengthening capacity for planning, management, and innovation and knowledge sharing.

\subsubsection{Improving Learning and Employability: Supporting Human Capital Development in Meghalaya}

ADB's first human development project in India, the Human Capital Development Project in Meghalaya is upgrading the infrastructure and improving the learning outcomes of 117 secondary and higher secondary schools. Interventions include earthquake-proofing and retrofitting, and addressing the skill needs in the state, with a focus on promoting native skills. The project is supported through $\$ 100$ million as loan and a Japan Fund for Poverty Reduction TA grant of $\$ 2$ million.

The project has supported the Meghalaya State Skill Development Society in repositioning its skill development approach with a focus on service, manufacturing, native (bamboo-, pottery- and textile-based craft), and integrated farming skills, both for waged and self-employment (Box 7). 


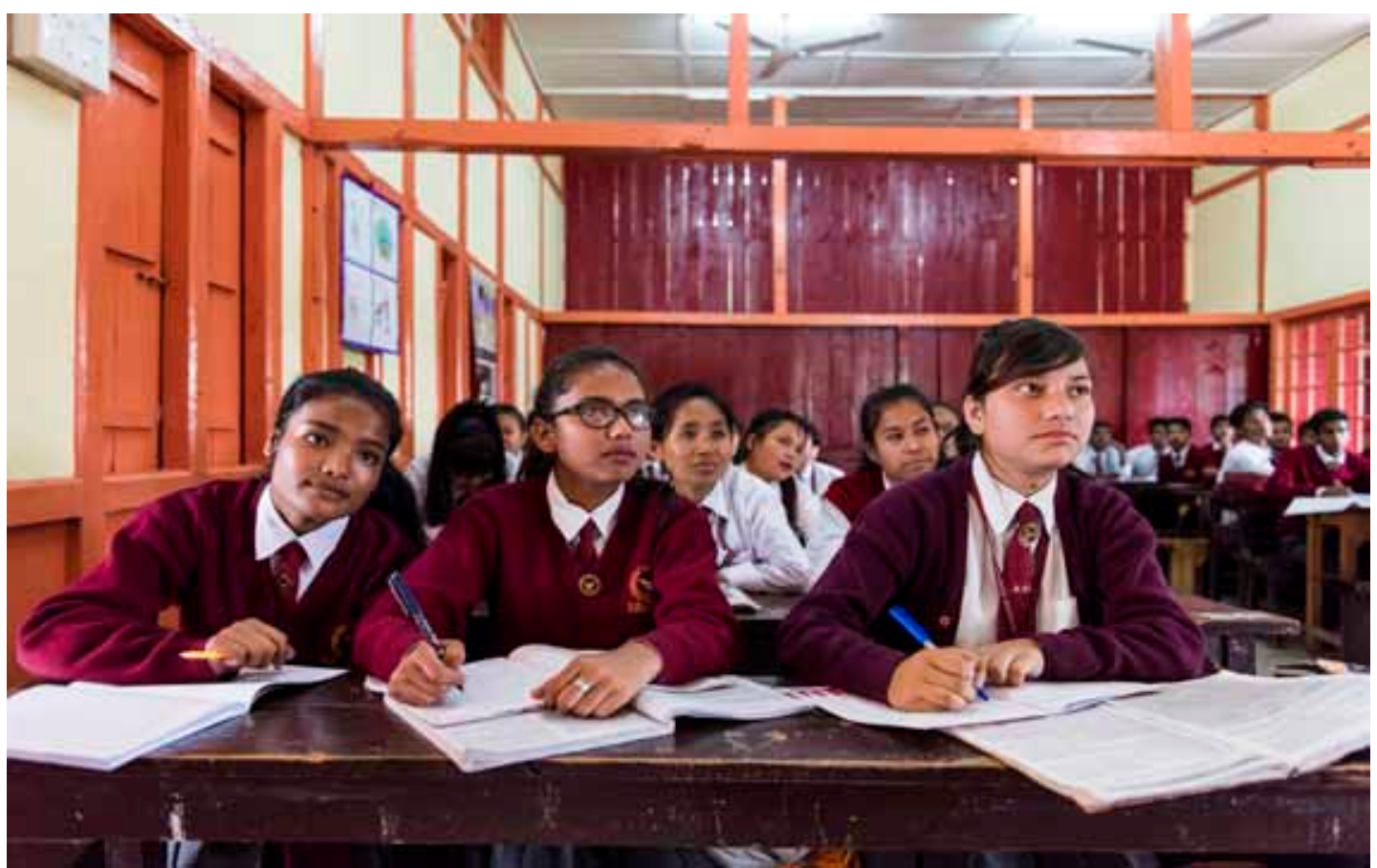

Improving learning outcomes. Students of Laitumkhrah Assamese Secondary School enjoying their retrofitted classrooms, rennovated under an ADB-supported project (photo by ADB).

\section{Box 7: From Skills to Market: Collective Efforts in Kenmynsaw Village}

The inhabitants of Kenmynsaw, a remote village in East Khasi depend on farming, fishing, and crafting bamboo-based utility items. Kenmynsaw is giving a new direction to its age-old bamboo craft. Capitalizing on the existing skills of the villagers, the Indian Institute of Technology, Guwahati in collaboration with the state government started a skill training program in 2015.

As a result, the institute, in collaboration with state government and ADB under the Japan Fund for Poverty Reduction TA 8468, has trained 200 craftspeople, mostly women. The artisans received training on using molds, semi-mechanized power tools, and treatment methods to produce standardized, highquality bamboo products and improve incomes. A reputed home-décor brand has committed to buying the products developed by the cluster. The state government is scaling up this initiative using loan funds to train another 1,800 craftspeople at an estimated cost of $\$ 440,000$.

"The training is very useful for us. It has brought speed, finesse, variety, and standardization in our work."

-Dlarson Byrsaw, a young trainee

"The retrofitting work has made the school safe and the project is also helping us to upgrade our library, computer room, and toilets. We are very happy and thankful."

-Padmawati Devi, Headmistress

The website www.shken.in has been developed to provide greater visibility for the cluster. 
Promoting local skills. Khasi women at a skills and production training session in Kenmynsaw village (photo by ADB).

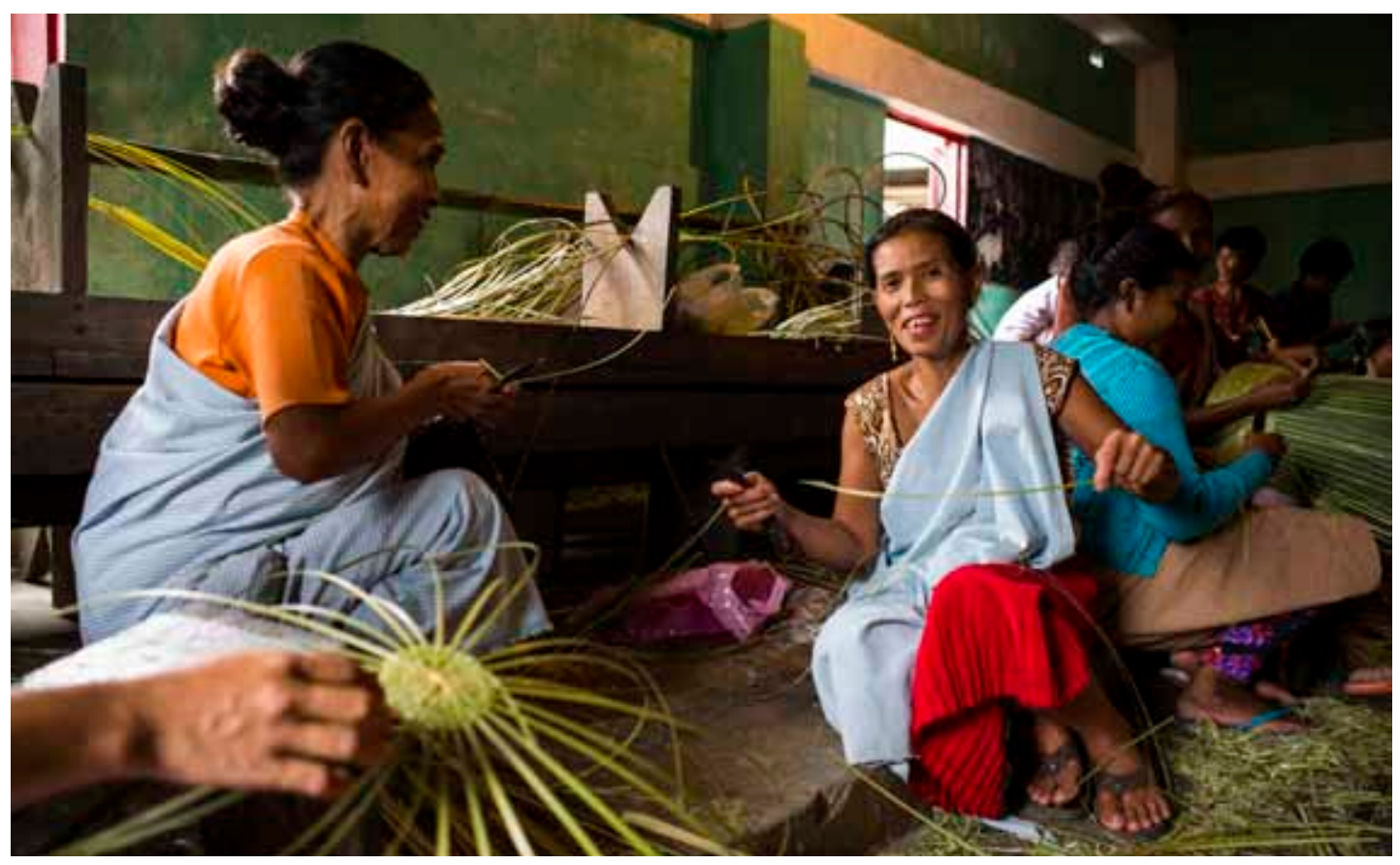

\subsection{Leveraging Finance for Infrastructure}

It is widely recognized that reliable high-quality infrastructure is a critical determinant of inclusive growth. Improved infrastructure helps efficient production and distribution of goods and services and enables access to economic opportunities. India's infrastructure financing requirements are immense: it is estimated that India will require investment of $\$ 4.5$ trillion to 2040 to develop infrastructure to improve economic growth and community wellbeing. Of this, given current trends, India is expected to be able to meet around $\$ 3.9$ trillion investment, implying an estimated cumulative infrastructure investment gap of about $\$ 526$ billion by 2040 (GOI, 2018a).

ADB's finance and public sector management (PSM) program includes financial intermediation loans with the objective of accelerating infrastructure growth by catalyzing private investment through PPP projects in road, airport, power (including clean and renewable energy), and water supply and sanitation.

The PSM projects include a comprehensive fiscal consolidation program in select states to generate fiscal savings and thereby assist the state to augment and sustain growth-enhancing development financing.

ADB provided a program loan of $\$ 400$ million and a TA grant of $\$ 700,000$ for the West Bengal Development Finance Program (WBDFP) in 2012, when the deteriorating fiscal situation in West Bengal placed pressures on public resources, constraining the delivery of public goods and services in the state. The loan helped the state government to achieve expenditure efficiency, improve revenue efforts, and increase debt management efficiency.

The WBDFP successfully facilitated policy actions that contributed to the state government's efforts to stabilize and consolidate its finances, generate fiscal space, reduce its debt burden, and increase development financing. ADB provided advisory and TA support that contributed significantly to capacity development and helped bring about the necessary policy and institutional changes to 
strengthen administration, systems, and procedures in key reform areas. Independent assessments recognized the West Bengal government's commitment to fiscal consolidation, and the government received several awards for e-governance in tax administration in 2014. The program enhanced the revenue performance of the state government in a broad-based manner, and improved the state's finances. Public investment (as a percentage of gross state domestic product [GSDP]) reached 1.3\% in FY2015 from $0.5 \%$ in FY2011, while simultaneously achieving a reduction of the fiscal deficit to $2.2 \%$ in FY2015 from 3.4\% in FY2011 (Figure 5).

Figure 5: Key Fiscal Indicators for West Bengal

4
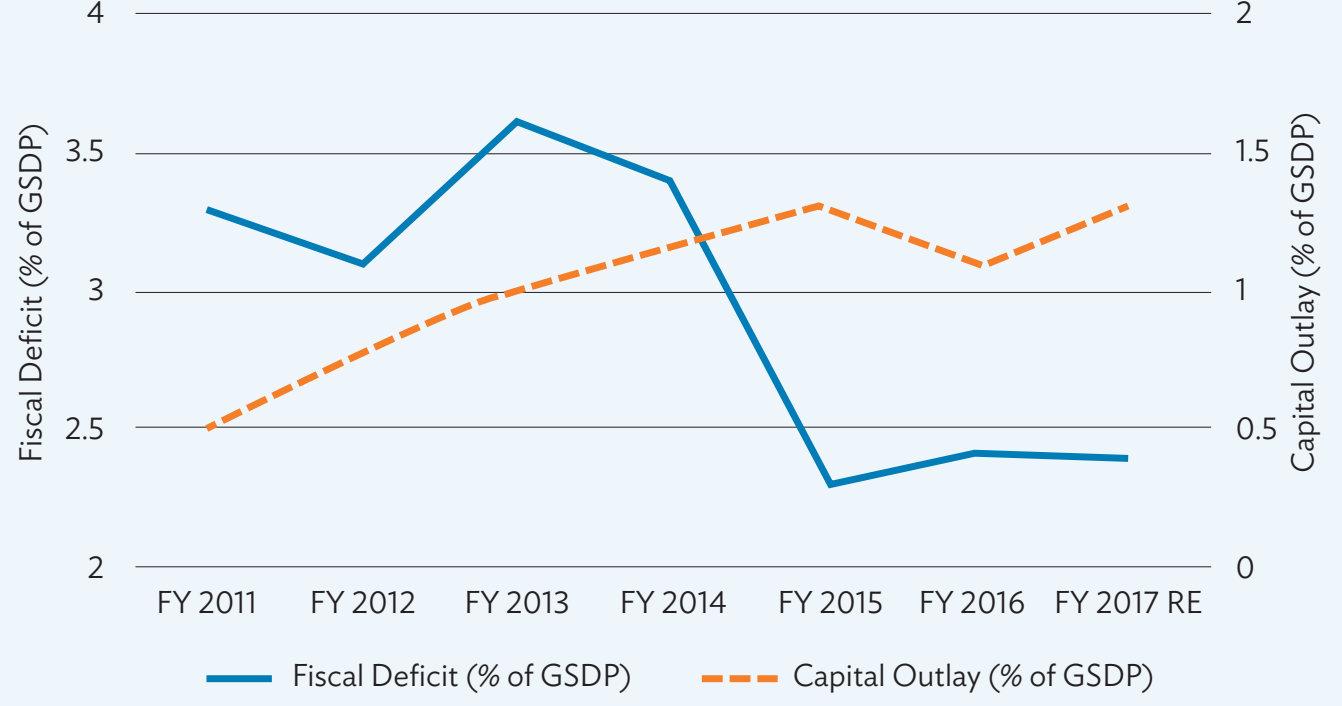

Note: RE = revised estimates

Source: Database on Indian Economy, Reserve Bank of India.

The Second West Bengal Development Finance Program (WBDFPII) follows up on the achievements of WBDFP, further deepening the reforms in expenditure rationalization, revenue augmentation, support for an enabling PPP framework (including viability gap financing), deepening the mediumterm fiscal and economic framework, extending automation of the integrated financial management system, and closing recurrent liabilities of state-owned enterprises through the adoption of one-off voluntary retirement schemes. These measures are expected to help raise state's public investment further to $2.2 \%$ of GSDP by FY2021.

\subsection{Private Sector Operations}

The Private Sector Operations Department (PSOD) of ADB undertakes direct debt, equity or guarantee transactions with private and commercial run state-owned enterprises. It funds projects or enterprises that lead to significant development impact, are commercially sustainable, and where ADB presence can add significant value. Most of ADB support under PSOD in India is directed toward renewable energy, financial inclusion, affordable housing, and small and medium-sized enterprises financing. 
Building infrastructure.

Support for renewable energy development is among the key interventions by ADB's private sector department in India (photo by ADB).

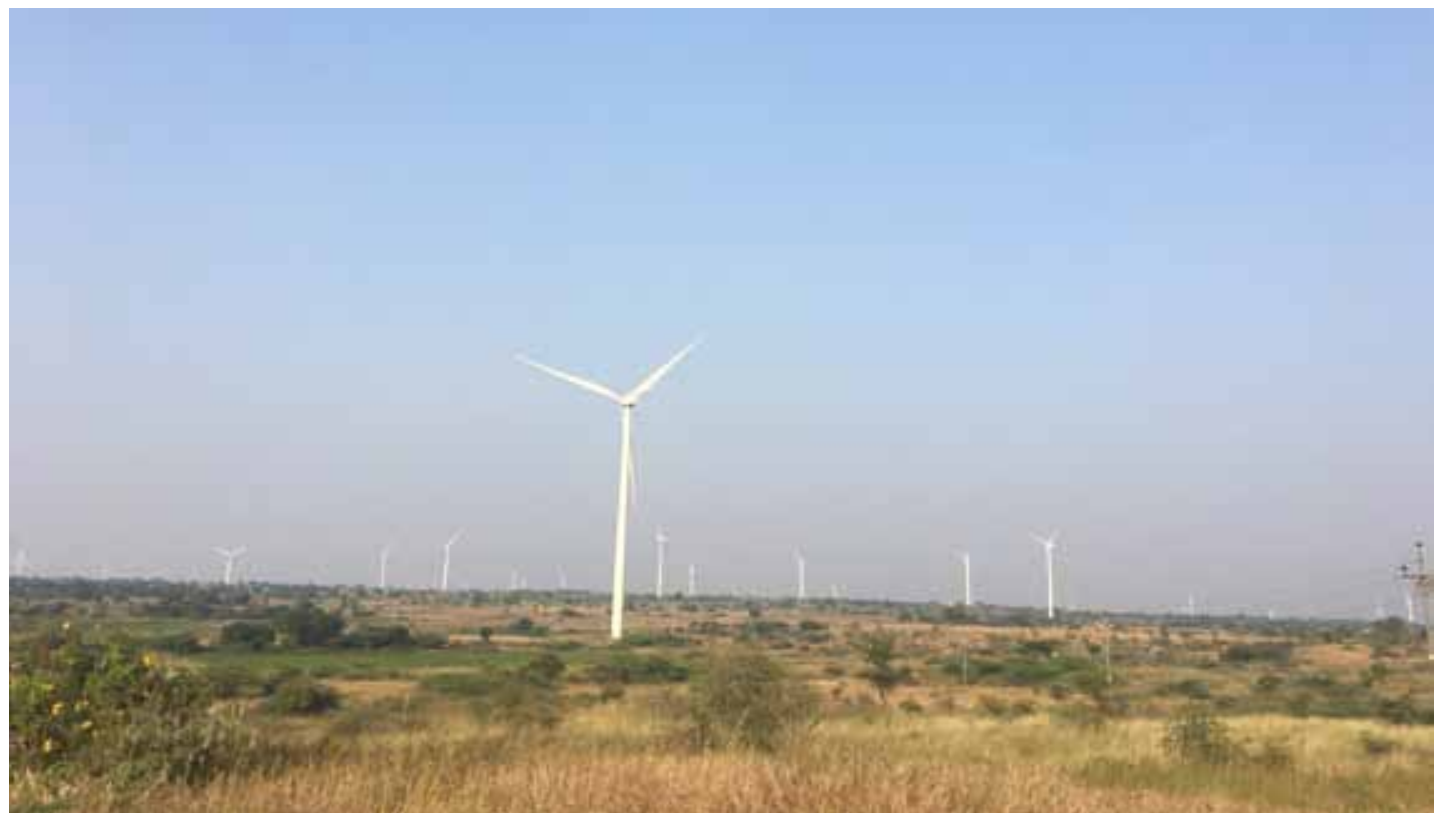

$A D B$ support for the private sector helped companies access more and longer-term funds in sectors that are otherwise considered high risk and face funding gaps, despite potentially large and positive social impacts (Boxes 8 and 9). The support also aimed to crowd in investment from other institutional investors. From 2014 till December 2017, ADB approved 29 projects (including seven regional deals) worth $\$ 3,160$ million comprising both debt and equity. PSOD operations in India have grown substantially. PSOD will continue this growth strategy, expanding its business in existing sectors, as well as expanding in areas where it has been less active so far.

\section{Box 8: ADB’s Microfinance Risk Participation and Guarantee Program}

Access to finance is a problem for most individuals and microbusinesses in India. Many microfinance institutions still struggle to obtain commercial funding to grow and meet the demands of low-income segments. ADB's Microfinance Risk Participation and Guarantee Program helps to fill these market gaps by sharing risks to facilitate local currency lending to the microfinance sector.

In India, ADB partners with two international and four domestic financial institutions that engage in wholesale lending to microfinance institutions, by sharing up to $50 \%$ of the default risk arising from loans made by partner financial institutions to microfinance institutions. India is the largest country of operation for the program, and between 2014 and 2017, the program has reached close to 2.7 million borrowers, of which $98 \%$ are women.

"Since 2012, when IFMR Capital and ADB pioneered this microfinance guarantee program in India, the program has helped unlock mainstream financing for the country's microfinance sector. It has set many high-quality microfinance institutions on a growth trajectory and made it possible for them to achieve scale. Over 3.9 million underserved households have gained access to finance, thanks to the program. Northern Arc greatly values its partnership with ADB."

-Kshama Fernandes, managing director and executive officer, Northern Arc.

Source: ADB. 


\section{Box 9: Equity and Loans to Support Financial Inclusion-RBL Bank}

Access to finance is a key issue for many customer segments in India, including lower-income individuals, women, and micro, small, and medium enterprises (MSMEs). To address this constraint and to support the government's financial inclusion initiatives, ADB has sought to identify financial institution partners with demonstrated ability to reach underbanked segments.

RBL Bank has been a partner of $A D B$ as a local currency lender in the Private Sector Operations Department Microfinance Risk Participation and Guarantee Program since 2012. It is a fast-growing Indian private sector bank with a business model focusing on supporting financial inclusion

In December 2015, ADB approved an equity investment of the rupee equivalent of up to $\$ 51$ million, and 5 -year loan of up to $\$ 100$ million and technical assistance (TA) totaling $\$ 800,000$ to RBL.

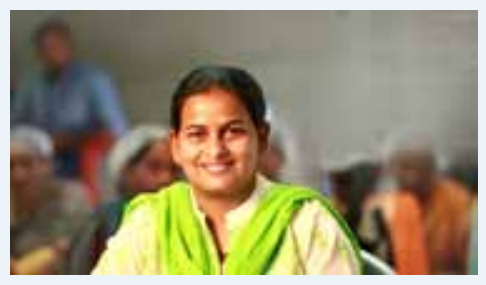

"The loan provided by RBL helped me in expanding my business. I was able to provide employment to 24 women."

- Rohini Walekar, a woman entrepreneur.

ADB led the pre-initial public offering equity round which attracted several other private investors, raising $\$ 74$ million. This led to a very successful initial public offering by the bank in August 2016 . The proceeds will support RBL's immediate and near-term capital requirements to maintain business growth primarily in its agribusiness, development banking and financial inclusion, and MSME portfolio. The 5-year loan addresses a financing gap in the market for longer tenor funds. ADB's capacity development TA is strengthening RBL's risk management capabilities and information technology infrastructure. ADB's support will overall help 600 small and medium-sized enterprises clients, more than 300,000 MSME clients, and up to 600,000 agricultural clients, primarily in underdeveloped states in India. It is also expected to support more than 600,000 women customers.

Source: ADB.

In line with the Government of India's vision of providing affordable housing for all, ADB is supporting Shapoorji Affordable Housing Project that is constructing 20,000 affordable housing units. ADB support fills the long-term funding gap in the affordable housing sector in India.

The ADB-supported India ReNew Power Investment Project, was aimed to increase reliance on renewable resources and reduce global greenhouse emissions. It was set to generate and sell at least 1,226 gigawatt-hours of electricity and avoid emission of 956,280 tons of carbon dioxide annually from 2016 onwards. ADB provided growth capital to ReNew Power Ventures to expand its asset base. ADB presence increased the company's credibility for raising capital from other sources and through an initial public offering. 
Housing for all. An ongoing affordable housing project at Virar in Mumbai (photo by ADB).

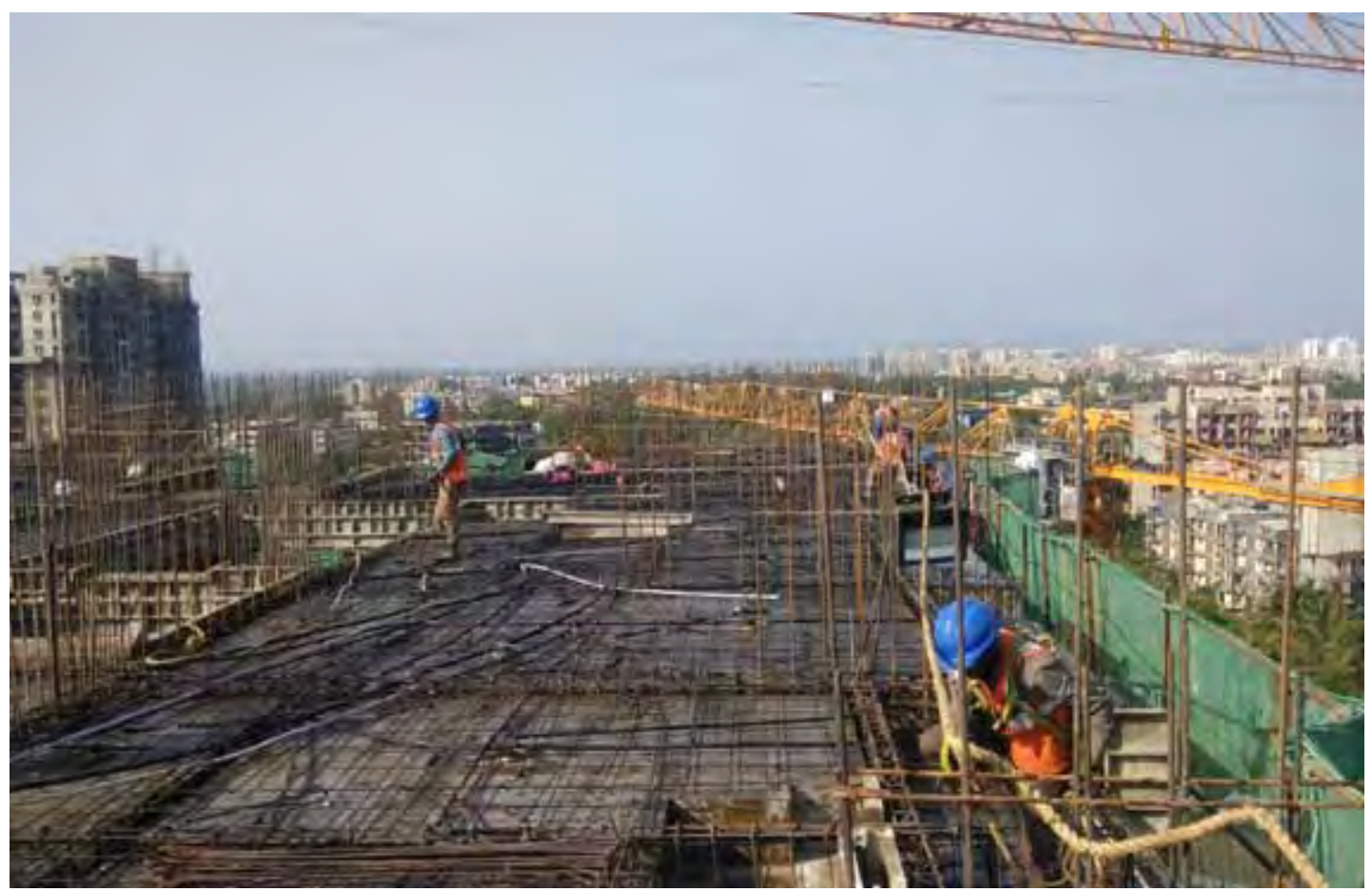

In December 2016, ADB committed a $\$ 390$ million loan facility to further support India's renewable energy targets. Half of this is funded through the Leading Asia's Private Sector Infrastructure Fund. ${ }^{10}$ The facility loan was structured to be utilized over 2 years to assist seven special purpose vehicles owned by ReNew Power Ventures to develop seven separate wind and solar power projects across six states in India (ADB, 2016). The facility will support the development of $754 \mathrm{MW}$ of renewable capacity by 2020 . The transaction will generate 2,121 gigawatt-hours of electricity and avoid emission of 1.9 million tons of carbon dioxide annually starting in 2020.

\subsection{Catalyzing Private Sector Investments for Enhanced Impact}

ADB's sovereign operations in India build partnerships with both government and private players. These are reflected in financial intermediation loans that crowd in private investment and participation. They also support projects with PPP elements, including modalities such as hybrid annuity contracts, performance-based construct-and-operate contracts, and post-construction O\&M contracts. Where possible, ADB endeavors to synergize sovereign operations with private sector operations (Box 10). In addition to fostering partnerships with private entities, ADB also collaborates with various bilateral and multilateral development agencies.

${ }^{10}$ Leading Asia's Private Sector Infrastructure Fund (LEAP) was launched in August 2016 by ADB with support from Japan International Cooperation Agency. LEAP is managed by PSOD. 


\section{Box 10: Sovereign and Nonsovereign Operations: Complementarities for Enhanced Support}

In 2015, ADB provided a $\$ 500$ million government-backed loan and a further $\$ 500$ million in nonsovereign lending to India's national transmission company, Power Grid Corporation of India Limited (POWERGRID).

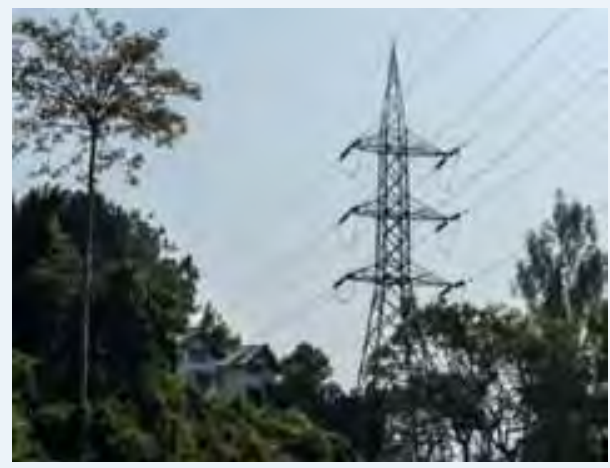

Green corridor. A transmission tower constructed by POWERGRID (photo by ADB).
The fundswere used to build and upgradehigh-voltage transmission lines and substations in Rajasthan and Punjab, as part of the Indian government's Green Energy Corridor initiative. To increase energy delivery from India's west to the southern region, the project also included new high-voltage direct current terminals in Chhattisgarh, Tamil Nadu, and Kerala, boosting interconnectivity between the regions from about 10 gigawatts (GW) to 16 GW by 2020 . The new transmission lines connecting renewable energy-rich areas to the national grid will enhance connectivity between the regions by bringing clean energy to more people, making the overall Indian power system more efficient, and improving India's overall energy security.

The combination of ADB's sovereign-backed and private loans is an innovative financing solution that provides POWERGRID with a large, competitive, and efficient source of funding. ADB's financing plays an important role in helping the country achieve its ambitious renewable energy targets, as well as increasing overall interregional interconnection capacity. ADB's presence as a key lender also helps attract other potential commercial cofinanciers and demonstrate ADB's ability to deliver financing solutions to companies like POWERGRID by accessing the combined knowledge and experience of its regional, country, and private operations.

\subsection{Advancing Subregional and Regional Cooperation}

\subsubsection{Regional Cooperation and Integration}

ADB has actively promoted regional cooperation and integration $(\mathrm{RCl})$ through the South Asia Subregional Economic Cooperation (SASEC) initiative since 2001. The long-term vision of the SASEC program is aligned to the frameworks of the South Asian Association for Regional Cooperation (SAARC) and the Bay of Bengal Initiative for Multi-Sectoral Technical and Economic Cooperation (BIMSTEC). It is also in line with the country's "Look East" policy that was stepped up in 2014 as the "Act East" policy. India is a key member of the grouping and has been playing a central role in the SASEC program.

\subsubsection{SASEC Vision}

SASEC is a forum to promote $\mathrm{RCl}$ practically, focusing on regional projects in three areas: transport, trade facilitation, and energy. Its operations are underpinned by SASEC Vision: Powering Asia in the 21st Century and SASEC Operational Plan (2016-2025), which set out strategic directions to leverage competitive industries through regional value chains to expand regional trade and commerce, and rolling pipeline of investment and TA projects in priority areas. As of December 2017, the SASEC portfolio consisted of 49 projects with cumulative cost of $\$ 10.7$ billion and ADB funding of about $\$ 6.2$ billion. 
SASEC vision document. Finance ministers from seven

SASEC member countries at the launch of SASEC Vision in New Delhi on 3 April 2017 (photo by Press Information Bureau, Government of India).

Facilitating connectivity. Signing of the Motor Vehicles Agreement at Thimphu on 15 June 2015, from left to right: Obaidul Quader, minister of Road Transport, and Bridges, Bangladesh; Lyonpo D.

N. Dhungyel, minister of Information and Communications, Bhutan; Nitin Jairam Gadkari, minister of Road Transport and Highways, and Shipping, India; and

Bimalendra Nidhi, minister of Physical Infrastructure and Transport, Nepal (photo by ADB).

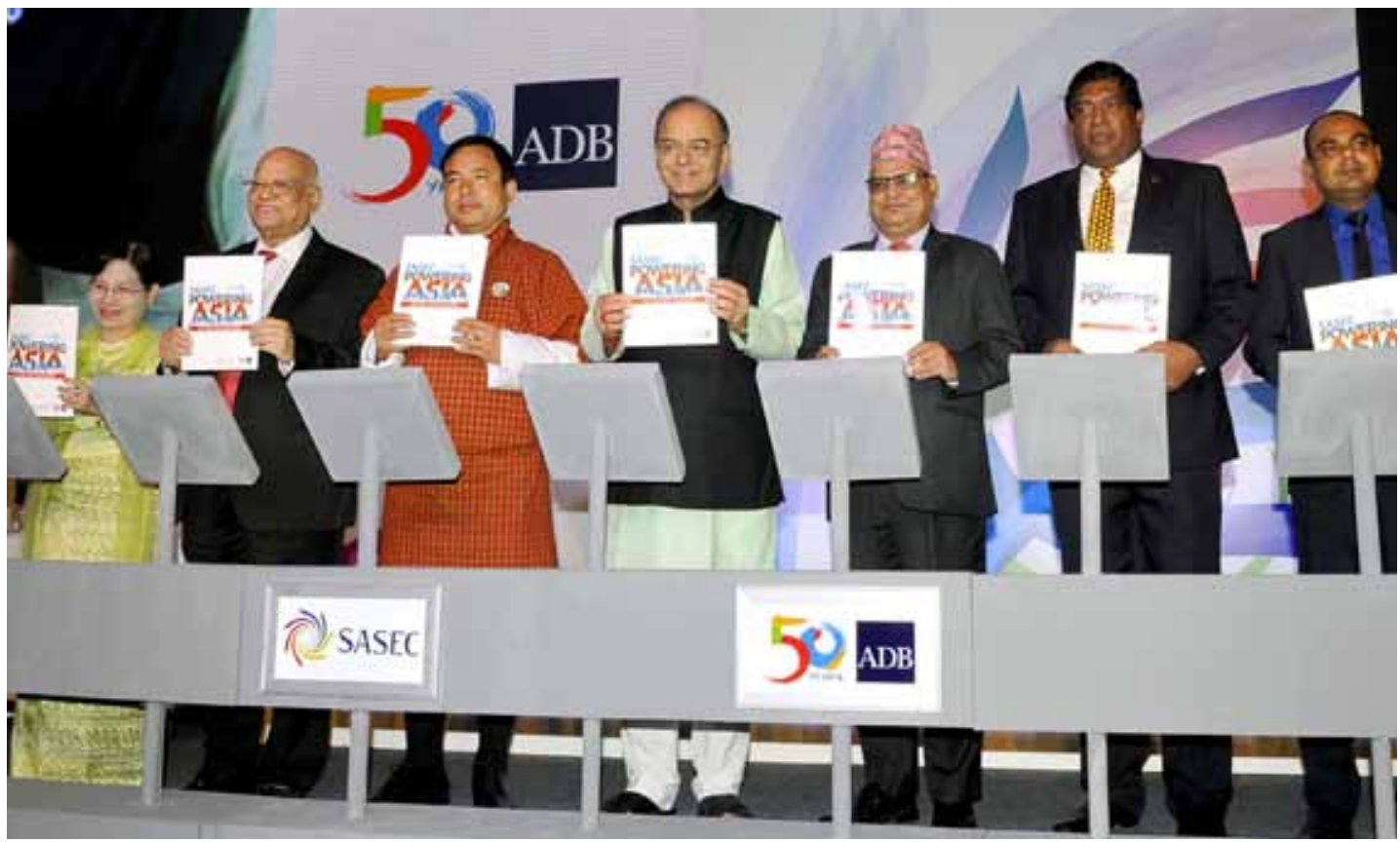

ADB supported the establishment of the BIMSTEC Secretariat in Dhaka in 2014 and the updating of the BIMSTEC Transport Infrastructure and Logistics Study as a framework for developing the region's transport and logistics sector, endorsed by member countries in 2014. In line with the Act East policy, India, as Chair of the BIMSTEC Transport Connectivity Working Group, plays a key role in promoting BIMSTEC connectivity.

The SASEC Trade Facilitation Strategic Framework (2014-2018), adopted by the SASEC members in March 2014, has achieved considerable progress across its five priority areas of customs modernization and harmonization, standards and conformity assessment, strengthening cross-border facilities improvement, through-transport facilitation, and institution and capacity building. India has played a

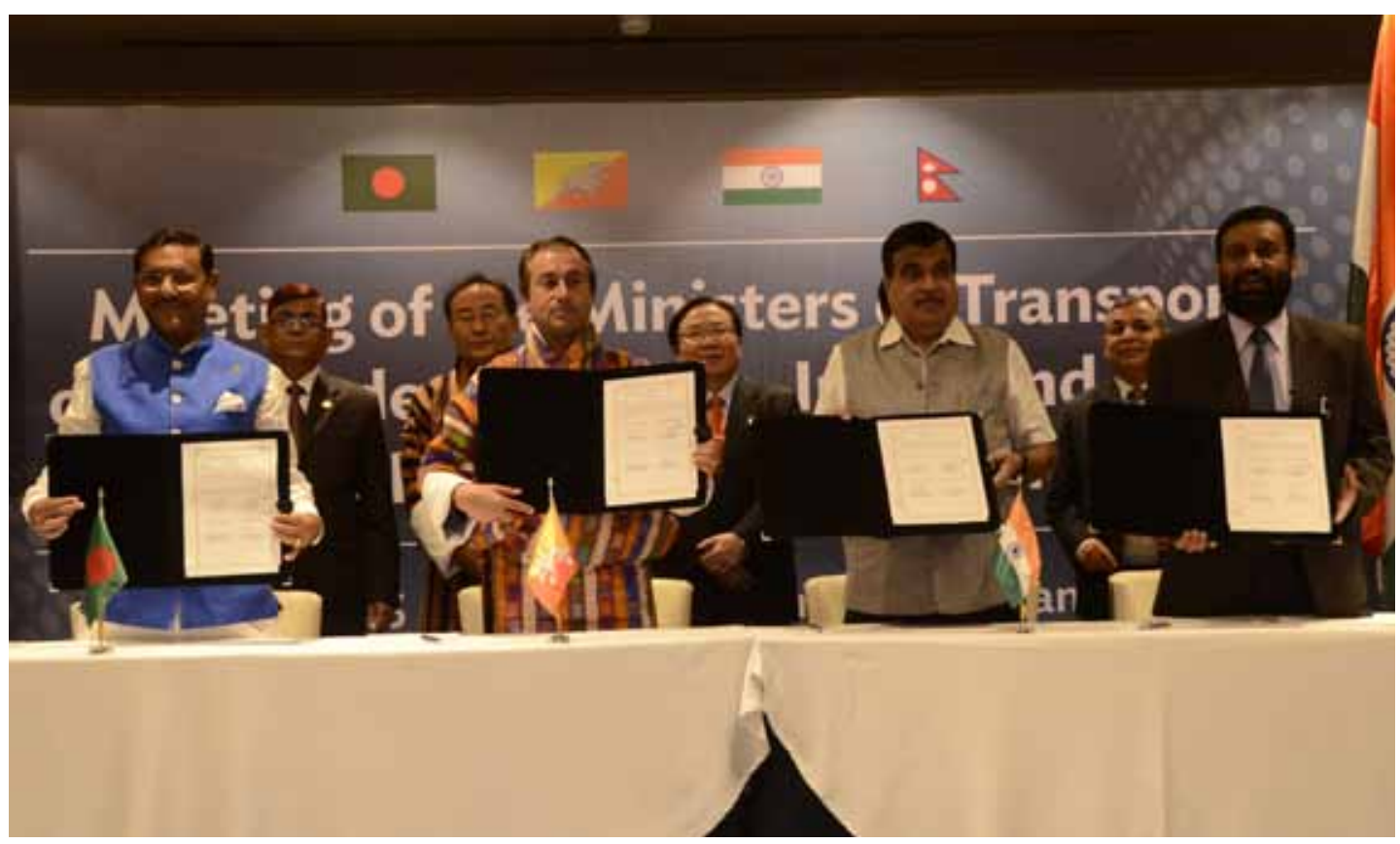


lead role through transport support to participating countries. The Bangladesh-Bhutan-India-Nepal Motor Vehicles Agreement, for facilitating passenger and cargo vehicular traffic between countries, was signed at a ministerial level meeting in Thimphu in June 2015. The use of an electronic cargo tracking system on inland routes in India, as well as for a Dhaka-Delhi cargo run was trialed, establishing the usefulness of the system in improving control and enhancing facilitation. India and Nepal signed an agreement to pilot the system in 2017. Progress has been made in terms of the diagnostic studies to define the SASEC agenda on sanitary and phytosanitary and technical barriers to trade.

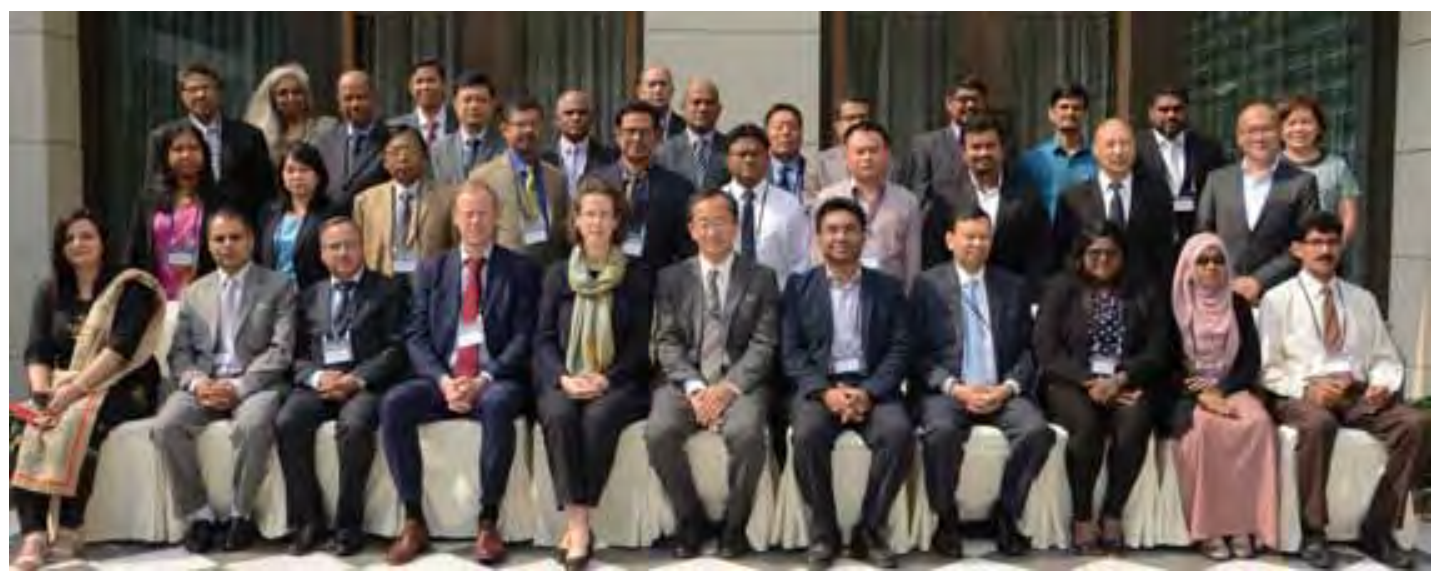

Deliberating regional outreach. Participants at SASEC Subregional Workshop on Sanitary and Phytosanitary and Technical Barriers to Trade National and Regional Diagnostic Studies 2018, held on 11-13 April in New Delhi, India (photo by ADB).

The focus of the SASEC Energy Working Group is on improving cross-border power transmission connectivity, promoting power trade, and cooperating on energy efficiency and clean power development. ADB's loan of $\$ 120$ million to Bangladesh in 2015 aims to double the capacity of the existing interconnection system which links the power grid of western Bangladesh at Bheramara and the grid of eastern India at Bahrampur. The two networks were first connected in 2013, under a previous ADB project. New transmission capacity will rise from $500 \mathrm{MW}$ to 1,000 MW. The growth in export of Bhutan's hydropower to India contributes to sustainable and diversified power sources in the total energy mix of the subregion.

\subsubsection{India Program under SASEC}

India has received cumulative $A D B$ assistance of over $\$ 2.0$ billion for 12 projects supporting regional transport and economic corridor development. About $10 \%$ of ADB's India portfolio addresses $\mathrm{RCI}$.

The SASEC Road Connectivity Investment Program signed in 2015 for $\$ 500$ million to finance Nepal-Bangladesh connectivity (Asian Highway No. 2) and Bhutan-Bangladesh connectivity (Asian Highway No. 48) through India's "chicken neck," and the SASEC-Myanmar corridor through Imphal-Moreh (Asian Highway No. 1). Large segments of the two high-priority SAARC transport corridors (SAARC Corridors 4 and 8 ) are being implemented under the program. 


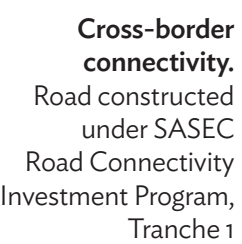

(photo by ADB).
Since 2014, ADB has been India's lead partner in developing the ECEC, the country's first coastal corridor.

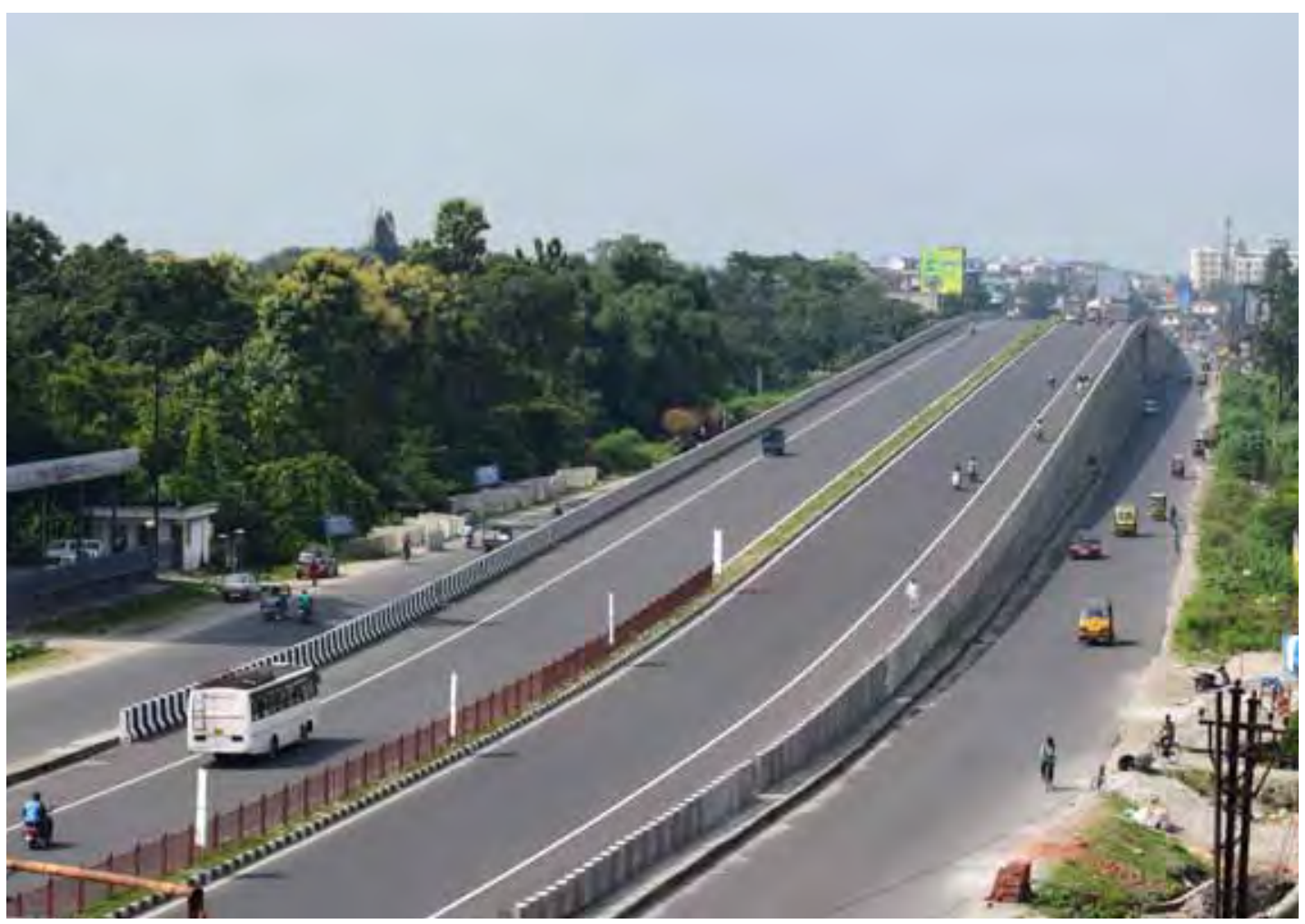

\subsection{Developing Economic Corridors: New Approaches for Infrastructure}

The Make in India program was launched by Prime Minister Modi in September 2014 to attract foreign businesses to invest in India. Building world-class infrastructure, including industrial corridors and smart cities, is the backbone of the program. It was complemented by the launch of Sagarmala (a port-led development strategy), Digital India, Skill India, and Start-up India programs, along with foreign direct investment reforms. ADB has been at the forefront of the Make in India initiative since 2014 through the design and implementation of the East Coast Economic Corridor (ECEC), India's first coastal corridor. One of the key objectives of the port-led industrialization strategy of ECEC is to create world-class manufacturing hubs near ports along the eastern coast that can serve as international gateways to the vibrant global production networks of Southeast and East Asia and forge deeper trading links with these countries.

Extending from Kanyakumari (Tamil Nadu) to Kolkata (West Bengal), ECEC presents a new approach for ADB's engagement in middle-income countries. The corridor development framework integrates the development of industry, infrastructure, urban services, and trade, underpinned by an institutional and regulatory framework that increases competitiveness through participation in regional and global value chains. ADB is also helping develop logistics infrastructure and management systems to further support this process.

The Visakhapatnam-Chennai Industrial Corridor (VCIC), running through Andhra Pradesh, was the first phase of ECEC. In March 2017, the VCIC Development Program, a \$631 million loan, was signed with the Government of Andhra Pradesh. It is a multisector loan with an integrated approach to 


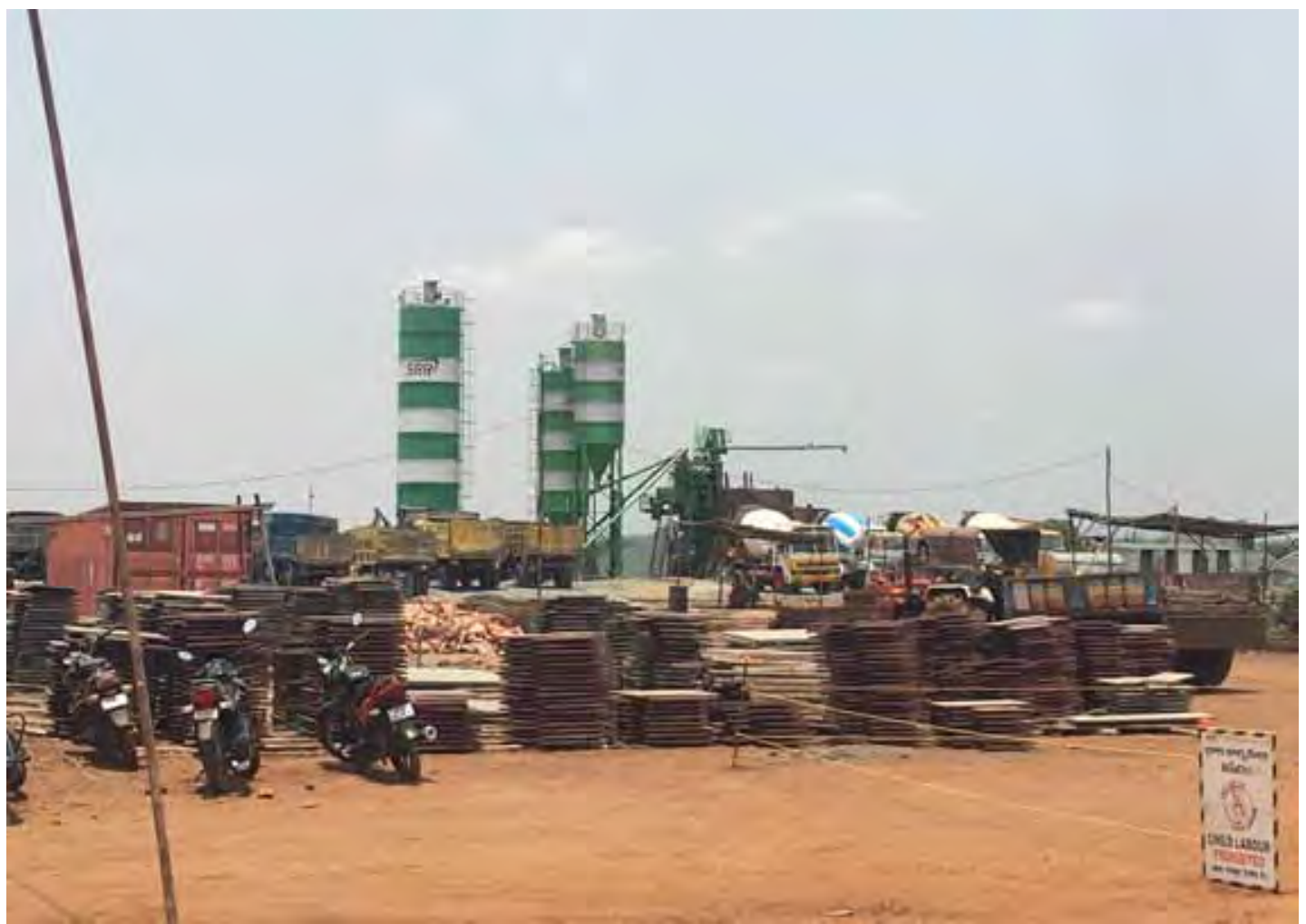

developing physical investments in roads, effluent and water treatment plants, drinking water pipes, storm drains, power substations, and transmission and distribution lines. It also includes support for strengthening the corridor-related institutional and regulatory framework, as well as in improving the ease of doing business. ADB's work contributed to the state topping the World Bank ranking of ease of doing business in 2017. The ensuing VCIC Master Plan focuses on industrial development of the Visakhapatnam node sites of Nakkapalle and Atchutapuram, and the Srikalahasti-Thottambedu node, and has identified priority projects worth nearly $\$ 2.4$ billion for the period 2018-2020.

\subsection{Promoting Gender Equality and Social Inclusion}

While India's economic growth has been remarkable, progress on human development and gender equality lags behind.1" Based on the UN's SDG indicators, India has made progress on some dimensions of gender equality, including maternal mortality, literacy, female participation in local governance structures, and access to basic services. However, the sex ratio for children under age 7 declined from 927 in 2001 to 919 in $2011 .^{12}$ Female employment in India's organized sector was low at 20.5\%. Low asset ownership, particularly land, affects women's access to extension services, training, new technologies, and credit.

\footnotetext{
${ }^{11}$ India ranked 108 (out of 144 nations) in the Global Gender Gap Index of the World Economic Forum Global Gender Gap Report 2017, down from 87 in 2016. Also in 2017, in the economic participation and opportunities for women, India ranked 139 while in the health and survival it is ranked 141, the fourth-lowest in the world.

${ }_{12}$ Sex ratio refers to the number of females per thousand males.
}

Corridor development. Ongoing infrastructure development at Naidupeta Cluster under $\mathrm{VCIC}$ in Andhra Pradesh (photo by ADB). 
The government prioritizes women's equal participation in the economy and protection from violence. Following government policies and programs on gender equality, ADB supports gender equality and social inclusion outcomes in ADB-financed projects by assisting in quality gender analyses at the design stage, robust action planning reflected in the monitoring framework, and provision of adequate human and financial resources for implementation. ADB selectively uses grants and TA to build capacity to design, implement, and deliver outcomes. It also documents good practices and lessons through knowledge products.

A significant number of ADB-assisted projects are categorized as gender equity (GEN) and effective gender mainstreaming (EGM), with distinctive gender-inclusive design elements and time-bound gender action plans (see Boxes 11 and 12). Gender equality has emerged as a strong theme in Indian operations, with the proportion of GEN and EGM projects increasing from 42\% during 2010-2013 to $45 \%$ during $2014-2017$.

\section{Box 11: Supporting Micro-Entrepreneurship for Women's Economic Empowerment}

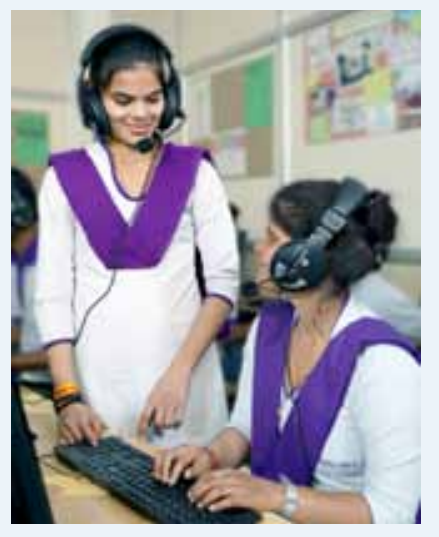

Empowering women. Two young women participate in outsourced business training (photo by ADB).
The Supporting Micro-Entrepreneurship for Women's Economic Empowerment is a $\$ 3$ million-capacity building grant, funded by the Japan Fund for Poverty Reduction and is associated with the Micro, Small, and Medium Enterprise Development Project. It was implemented during 2010-2018 with the primary objective of helping low-income women access financial resources, services, and market opportunities in selected states of India.

The executing agency was the Department of Economic Affairs under the Ministry of Finance and the implementing agencies were the Small Industries Development Bank of India and the Rural Skills Division of the Ministry of Rural Development. It was later implemented through the Deen Dayal Upadhyaya Grameen Kaushalya Yojana (DDUGKY), the flagship program of Ministry of Rural Development. DDUGKY trains and places poor rural youth in wage employment and mandates inclusive program coverage, including a 33\% reservation for women.

The key achievements of this grant project are as follows:

- Provision of master trainers and training outreach. Across seven states, a total of 400 trainers, of whom $49 \%$ are women, were trained to become DDU-GKY trainers. These master trainers used the 160-hour instructional material developed under this initiative and trained 8,498 poor women, of whom $74 \%$ were from underprivileged groups.

- Provision of training in different trades. Women trainees received training in different trades such as sewing machine operation, healthcare general duty assistance, and business process outsourcing. Further, 320 women entrepreneurs attended lateral learning workshops held in five states.

- Experience sharing and peer networking. Women micro-entrepreneurs shared their personal stories on overcoming the challenges of social and family barriers, the pressure to conform to traditional gender roles, and the effort required to sustain and grow their business ventures while simultaneously managing family and social responsibilities.

- Policy inputs. The assistance enabled the Ministry of Rural Development to document gender and social inclusion related policy and strategy recommendations, and prepare a paper on improving efficiency and effectiveness of DDU-GKY.

Source: ADB. 


\section{Box 12: Enhancing Women's Participation in Community Resource Management}

Orissa Integrated Irrigated Agriculture and Water Management Investment Project was designed to enhance the productivity and sustainability of existing irrigation schemes. It emphasized beneficiary participation, particularly women, in taking decisions to manage the planning construction, and operation and maintenance of irrigation systems as an equal partner of the government.

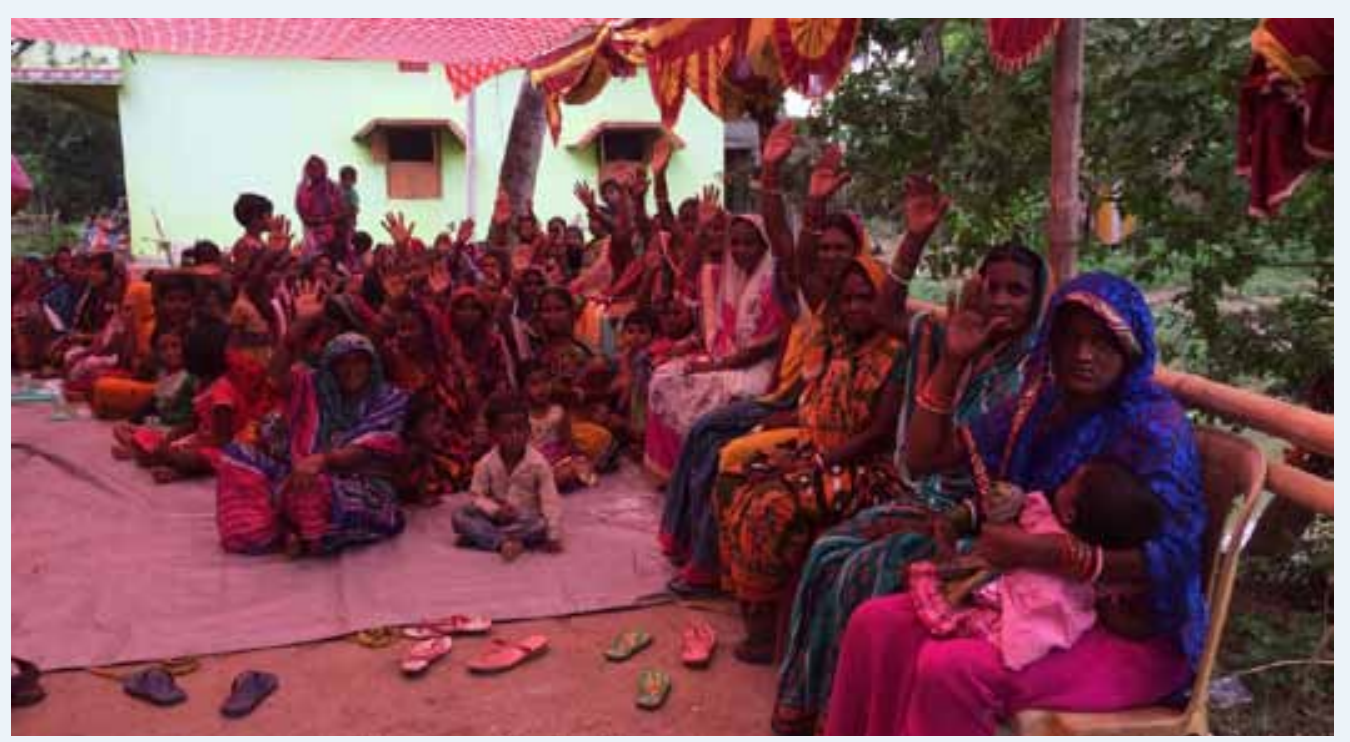

Enhancing women's participation. Women in an Odisha village participate in a community consultation held under the Orissa Integrated Irrigated Agriculture and Water Management Investment Program (photo by ADB).

"This is a very important position and we [women] are heard in the meeting[s] and we [women] can take decisions. I participate in all monthly meetings and ensure that interests of all farmers [both men and women] are taken care of."

- Nalini Lenka from Kothi Village in Jagatsinghpur District is a Water Users' Association executive committee member in Taldanda Subproject area

Source: ADB. 2017. India: Orissa Integrated Irrigated Agriculture and Water Management Investment Program - Project 1: Project Completion Report. https://www.adb.org/projects/documents/ind-38411-023-pcr. 


\section{IMPROVING OPERATIONAL AND ORGANIZATIONAL EFFECTIVENESS}

India has been the largest borrower of ADB's sovereign lending since 2010; therefore, achieving operational and organizational effectiveness of ADB assistance in the country assumes even greater significance.

ADB operations in India-spanning 6 sectors and covering 25 states-involve a diverse range of project partners with varied experience and capacities. Delivering efficient, timely, and consistent project outputs and outcomes remains a challenge, especially given the increasing number of projects in low-income states (LIS), including those in the northeastern region.

$A D B$ operations aim to achieve greater development effectiveness through efficient portfolio management; continual efforts to analyze and strengthen processes and systems; and strengthening the capacities of project partners. Adoption of country procurement and safeguards systems at the agency level, strengthening the Capacity Development Resource Center (CDRC), and developing a robust country knowledge plan are some notable steps in this direction.

Achieving operational efficiency is a prerequisite for the achievement of development effectiveness. Portfolio performance is a key determinant of operational efficiency, but is fraught with challenges. A significant $62 \%$ share of ADB's India portfolio is in LIS, which do not have enough institutional capacity to follow ADB's procedures, and face challenges in achieving project readiness, as well as in project implementation performance. Further, the performance of projects can be impeded by inadequate procurement and contract management capacity of executing agencies and poor performance of contractors.

A multipronged approach has facilitated an improvement in overall operational and organizational effectiveness. Improved portfolio performance has contributed to this.

\subsection{Improving Portfolio Performance}

ADB's India portfolio, notwithstanding the challenges, has registered steady improvement in performance in recent years, as measured by two prime indicators: contract awards and disbursements. The sovereign disbursements surged from an average of \$1.37 billion during 2014-2016 to an alltime high disbursement of $\$ 1.86$ billion in 2017 . Similarly, the contract awards increased from an average of $\$ 1.90$ billion during 2014-2016 to all time high contract awards of $\$ 2.43$ billion in 2017. India's disbursement ratio (commitment basis) has also shown a marked improvement and touched 27.9\% in 2017 (Figure 6). Of the total $\$ 12.9$ billion active sovereign loans in India (committed as of 31 December 2017), a total of $\$ 5.9$ billion (45\%) has been disbursed, leaving an undisbursed loan amount of $\$ 7.1$ billion (55\%). 
Table 4: India Loan Disbursements, 1986-2017

(\$ million)

\begin{tabular}{|c|c|c|c|c|c|c|}
\hline Loan & 1986-2013 & 2014 & 2015 & 2016 & 2017 & $\begin{array}{c}\text { Total } \\
(1986-2017)\end{array}$ \\
\hline $\begin{array}{l}\text { OCR } \\
\text { sovereign }\end{array}$ & 18,248 & 1,402 & 1,333 & 1,381 & 1,862 & 24,226 \\
\hline $\begin{array}{l}\text { OCR } \\
\text { nonsovereign }\end{array}$ & 1,296 & 230 & 474 & 357 & 342 & 2,699 \\
\hline Total & 19,545 & 1,631 & 1,807 & 1,738 & 2,204 & 26,925 \\
\hline
\end{tabular}

$\mathrm{OCR}=$ Ordinary Capital Resources

Note: Numbers may not sum precisely because of rounding.

Source: ADB.

Figure 6: Sovereign Disbursement Ratio (Project Loans)

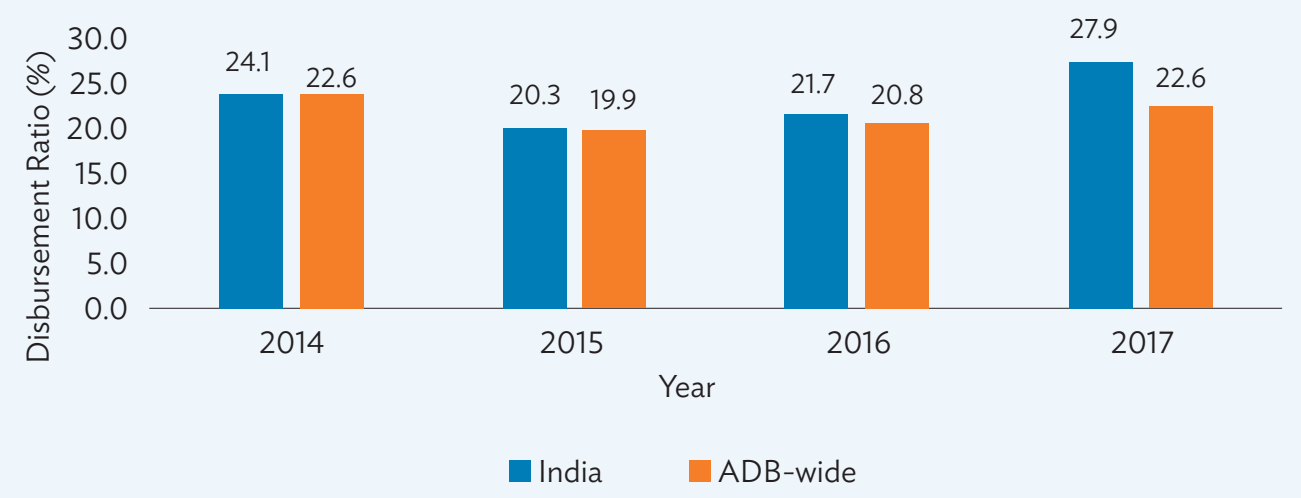

Note: Disbursement ratio is the ratio of total sovereign loan and grant disbursements (given year or period) to undisbursed balance effective/non-effective (signed) loans at the beginning of the year.

Source: ADB.

Regular portfolio review meetings involving $A D B$, the government, and executing agencies are conducted to resolve project implementation issues and foster information sharing among implementation partners. Further, ADB staff mobilizes regular review missions to provide support for implementation on ground. Increased delegation of projects and allocation of more staff resources at the India Resident Mission of ADB has also facilitated frequent and closer interaction with executing and implementing agencies, quick decision-making, and resolution of implementation issues.

Enhanced focus on project readiness is another important measure for the quick start-up of project implementation. ADB has been working closely with the government to ensure better project quality at entry, and timely project processing, by stringently adhering to achievement of key project preparatory milestones prior to loan negotiations and loan signing. The project readiness checklist and pipeline review meetings are key instruments in this regard. 


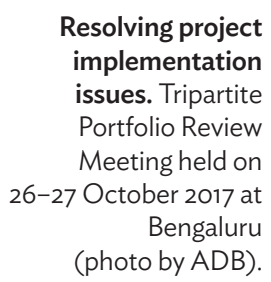

(photo by ADB).

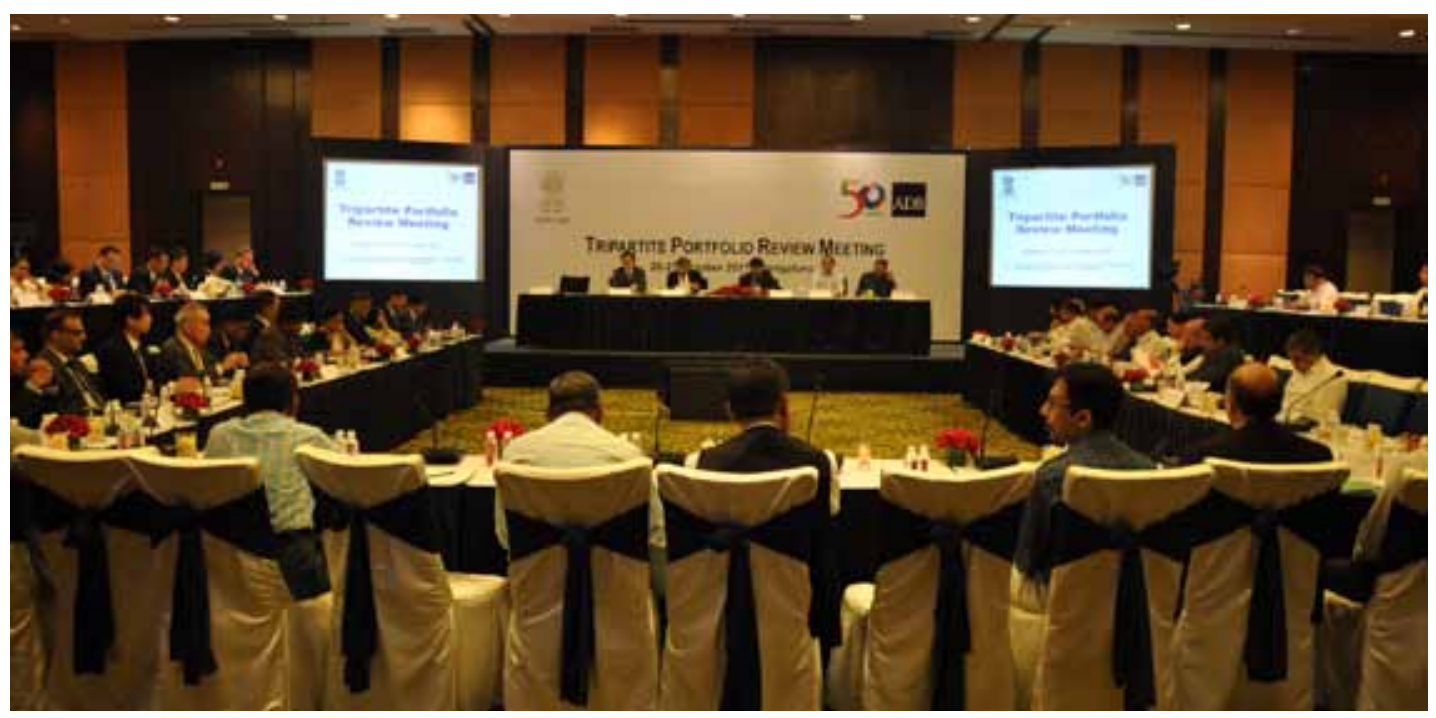

\subsection{Strengthening Processes for Greater Effectiveness}

ADB has undertaken procurement reforms, which consist of a number of innovations aimed at reducing procurement time, improving the overall quality of procurement and project outcomes, and strengthening the delivery of ADB's procurement support.

A groundbreaking achievement has been the approval of the adoption of country procurement and safeguard systems at the agency level for an $A D B$-assisted power sector project, which is the first ever use of country systems approved by ADB (Box 13).

\section{Box 13: Pioneering the Adoption of Country Systems}

In April 2017, ADB and India signed a \$175 million loan to Power Grid Corporation of India (POWERGRID) to finance high-voltage transmission systems to distribute electricity from new mega solar parks to the interstate grid. The project is groundbreaking, as it uses the state-owned utility's own systems, which are well developed and aligned with international standards, to procure project-related goods and services and to safeguard communities and the natural environment from any negative impacts.

Using country systems, obviating the need for a dual system to meet the requirements of both the borrower and ADB, will reduce the cost of doing business in the long run, even though it may call for close monitoring and consultation in the initial stages.

Well-developed country systems can also increase the effectiveness of development assistance by providing a harmonized platform to implement the project operations meeting the requisite standards.

The use of country systems offers a chance to promote efficient processes to deliver faster and more effective assistance to the countries and beneficiary communities without relying on the system of the external development partners.

Source: ADB. 


\subsection{Investing in Long-Term National Capacities}

As a long-term and committed development partner of India, ADB integrates elements of governance and capacity development in its operations, for example through policy-based loans that contribute to improved governance, ease of doing business, and fiscal management at the state level. Capacity building is supported through technical assistance (TA), and also embedded in lending projects. In addition, ADB has established the CDRC at the India Resident Mission to support executing agencies on operational as well as technical subjects, to enable better project implementation.

\subsection{Capacity Development}

The India Resident Mission established the CDRC in 2010 as part of the Portfolio Management Unit to undertake structured and demand-driven programs for capacity development of executing agencies to help improve project design and implementation with TA support. The CDRC identifies training topics through a training need assessment survey conducted among executing agencies. Training content is formulated in consultation with training institutes, executing agencies, and ADB project officers to make the programs relevant for operations. The CDRC also collaborates with various national academic and training institutes to make capacity development local resource driven and economical. The CDRC uses web-based and online resources for its day-to-day operations like announcing training calendar, obtaining nominations, and selection and tracking of trainees. Further, CDRC conducts business opportunity seminars to disseminate business opportunities available under ADB projects and to attract good quality contractors and consultants. These seminars are conducted in collaboration with national contractor and consulting organizations, leveraging the partnership and financing of the Export Import Bank of India. Between 2014 and 2017, the CDRC has delivered several training programs, benefiting more than 3,000 government officials, executing and implementing agency staff, contractors and consultants (Table 5). For logistic management, opportunities for drawing upon partnerships and resources of national training institutes are maximized.

Table 5: Training Topics Covered

\begin{tabular}{ll}
\hline ADB Procedures & Procurement and Consultant Recruitment, Procurement Clinic - \\
& Environmental \& Social Safeguards - Disbursement Procedures - ADB \\
& Orientation Forum for Project Directors and new executing agencies \\
& Gender
\end{tabular}


Training for better portfolio performance. Participants in a training program for agency officials organized by the Capacity Development Resource Center (photo by ADB).

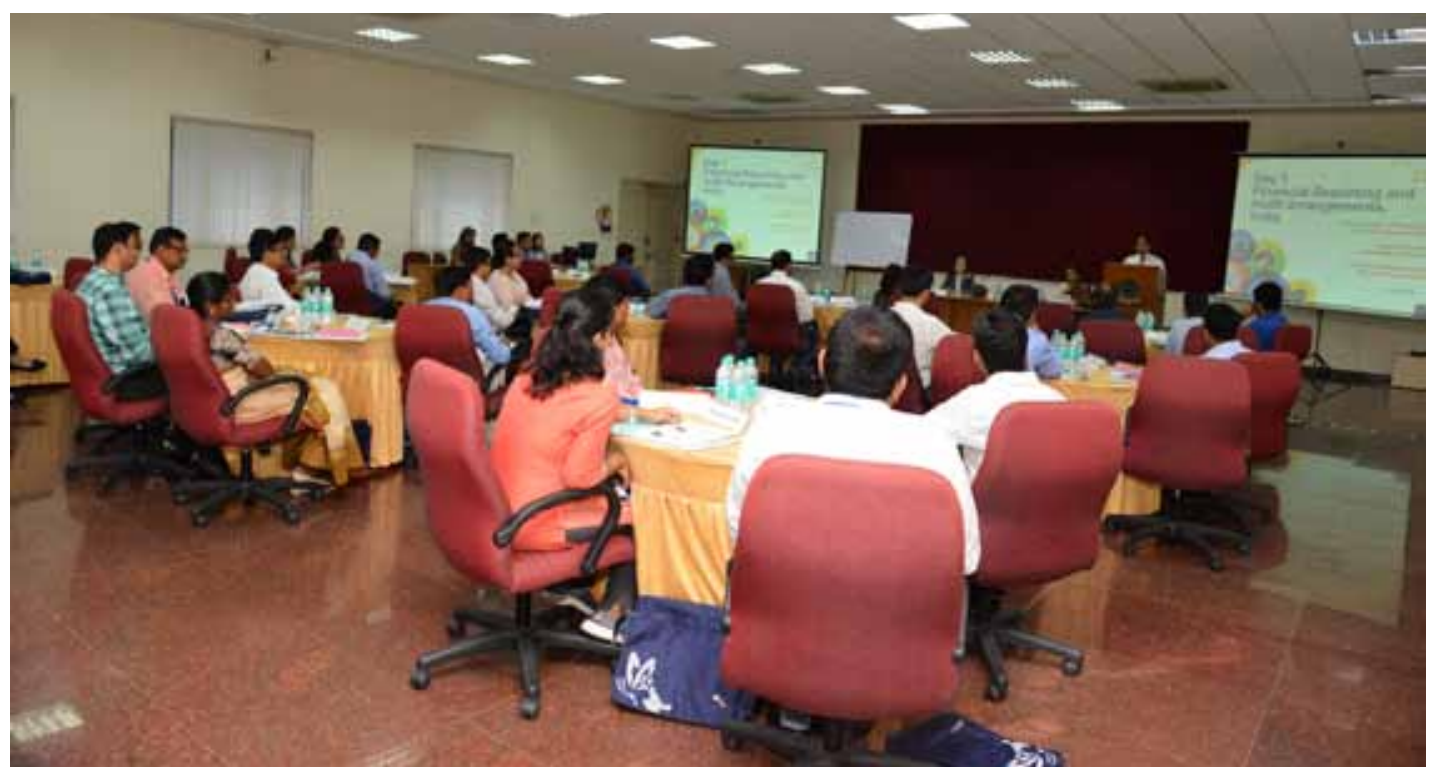

The CDRC programs have been acknowledged as an important Finance Plus contribution for India operations by the government and ADB Management. The CDRC trainings have contributed to improved portfolio performance, by helping enhance project preparation, including project readiness at entry, by targeting executing agencies early in the project cycle.

An impact assessment study of CDRC operations elicited positive feedback from officials of project executing agencies, the target audience of CDRC's capacity building programs.

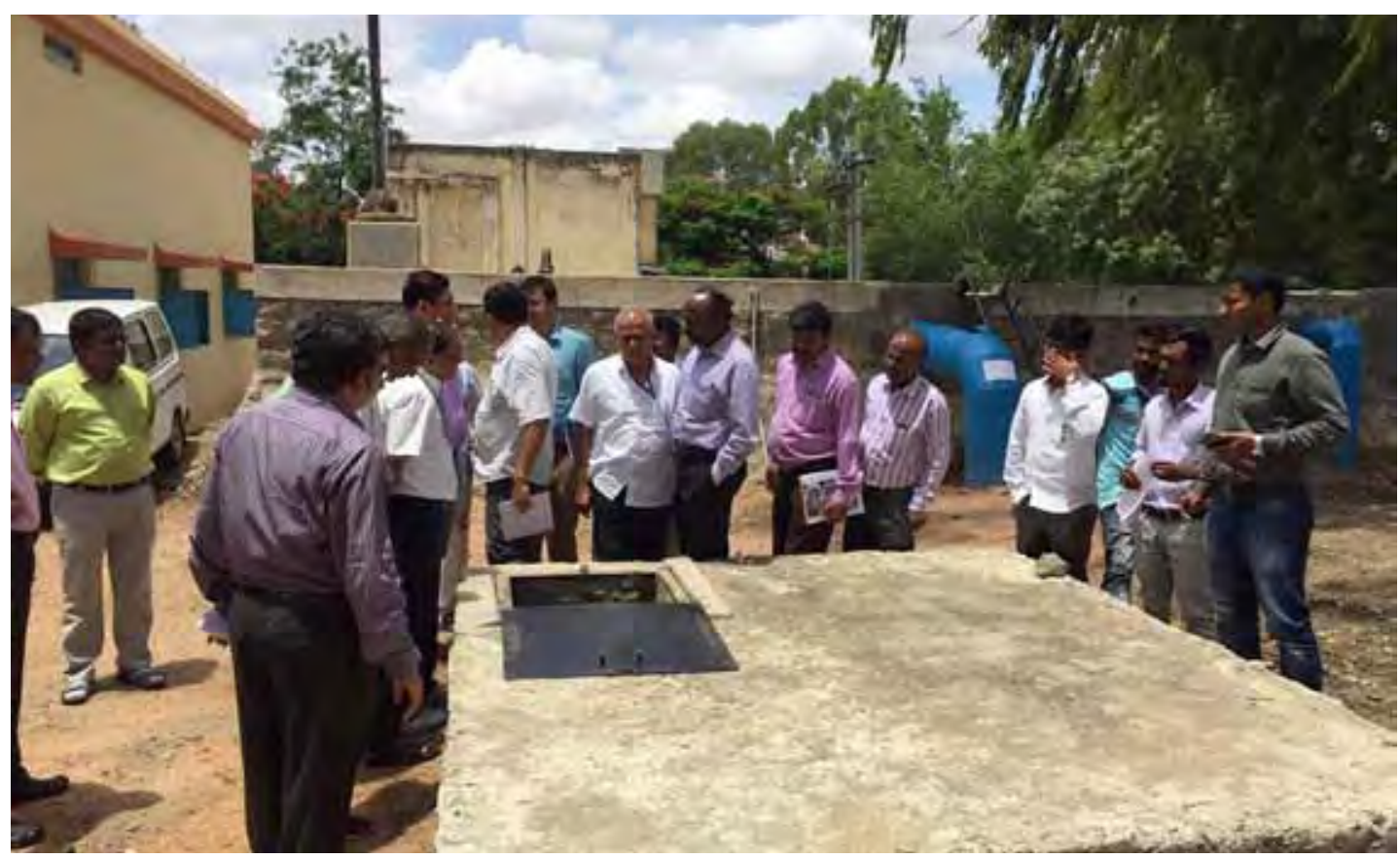

Knowledge sharing. Site visit to llkal city in Karnataka where $24 \times 7$ water supply system was implemented under ADB-assisted North Karnataka Urban Sector Investment Program. This was part of a program for knowledge sharing and showcasing of good practices organized by the Capacity Development Resource Center in June 2017 at Hubballi, Karnataka (photo by ADB). 


\title{
Feedback from Executing Agencies
}

\author{
Joy Kumar Singh, project director, North East State Roads Improvement Project (Manipur)
}

"Since the department had no prior experience in working with MDB [multilateral development banks], it took 16 months to complete the procurement process for the North Eastern States Roads Investment Programme with the help of two staff consultants from ADB. For the second project, without any outside assistance, the procurement process will be completed in 6 months, which indicates a saving of 10 months' time as well as savings for ADB as consultants were not required. While in the first project the department needed complete handholding by ADB, for the second project the entire process has been completed independently by the department. Savings on cost of procurement and savings of time have been a direct benefit from the CDRC training programs on FIDIC [International Federation of Consulting Engineers] contract management, procurement of contractors and consultants."

\section{Suresh Gupta, executive engineer, Rajasthan Urban Infrastructure Development Program}

"Knowing about FIDIC condition of contracts has been beneficial as without these we could not have completed consultant selection and bidding of two large international competitive bidding contracts so quickly. Used these learnings in RUIDP [Rajasthan Urban Infrastructure Development Program] Phase III (RUSDP-Loan 3183) where we completed consultant selection process and civil works bidding process speedily. The training programs organized by CDRC have not only helped RUIDP Phase III save in terms of time and cost but also improved resource utilization and ensured faster delivery of public good."

\subsection{Strengthening Knowledge Development}

India was the first country to develop an action plan for knowledge management in 2013. ADB started to use knowledge solutions to maximize the effectiveness of its operations in India over the 2013-2017 country partnership strategy period, by promoting creation and dissemination of analytical and operational knowledge.

Building on the strong ownership at the state level, ADB's support for the East Coast Economic Corridor (ECEC) studies resulted in comprehensive development plans in Visakhapatnam-Chennai in Andhra Pradesh, Chennai-Kanyakumari in Tamil Nadu, and Odisha, setting out spine and network infrastructure connecting the identified industrial nodes, along with the institutional interventions to support the economic growth. Transport, energy, and urban strategies and priority investment projects were identified. The plan is followed by detailed master planning of the industrial nodes undertaking detailed land use and infrastructure planning with financial structuring, which provides a basis for harmonized industrialization and urbanization. These studies have resulted in the first multisector project for India (described in Section 2.10). ADB has committed to $\$ 1$ billion per year on ECEC over the next five years, which are to be identified through the studies being undertaken.

$A D B$ is also responding to the knowledge needs of various agencies to undertake strategic planning studies on a range of issues, such as (i) investment climate and productive industrial clusters assessments in Rajasthan, identifying last mile connectivity investments, and supporting regulatory changes; (ii) the Expressway to Association of Southeast Asian Nations study in Assam outlining strategic initiatives to help increase per capita income and productive employment by developing a more competitive manufacturing sector and building quality infrastructure; and (iii) infrastructure framework plan for inclusive growth in Uttar Pradesh, which set out a pathway to create labor intensive industrial growth with urban agglomeration through transport and power networks, logistics parks, and skills development. 
Figure 7: Selected Knowledge Products
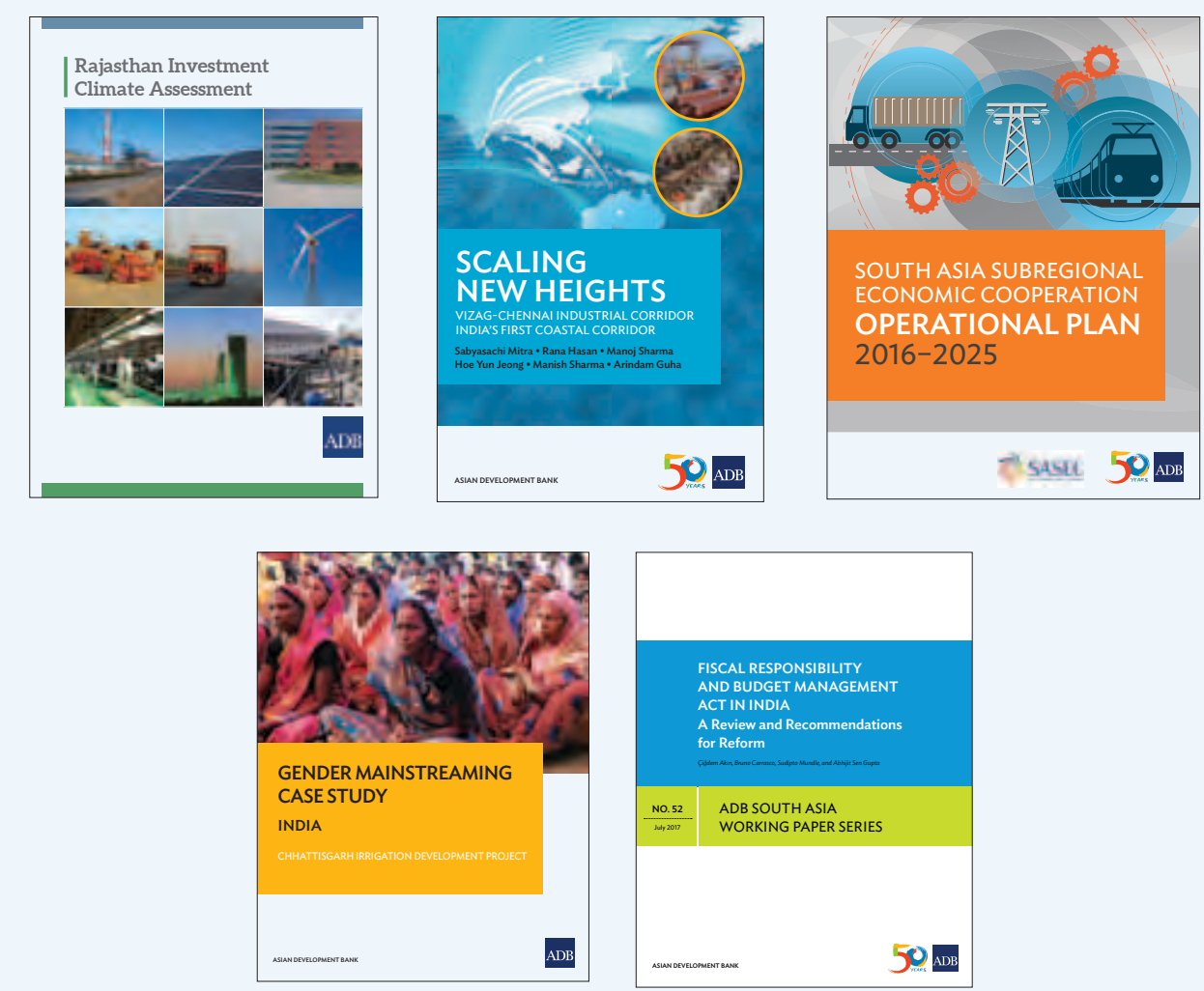

Source: ADB.

In terms of policy advisory, ADB has responded to the requests from (i) the Fiscal Responsibility and Budget Management Review Committee on the international best practices in to pursue fiscal stability and optimal debt management; (ii) the National Institution for Transforming India (NITI Aayog) to analyze various scenarios for sectoral employment and economic growth for India from 2016-2032; and (iii) Tamil Nadu Guidance Bureau to identify and support implementation of reform measures to improve ease of doing business.

ADB's sector and thematic work on India have also been documented, published, and disseminated through the electronic media and at workshops and seminars. These include reports, papers, and databases on topics such as $24 \times 7$ water supply works in Ilkal town in Karnataka, gender equality references for 18 states, and a South-Southeast Asia connectivity study. Furthermore, technical studies were conducted to set up of Multimodal Logistics Parks, which are followed by a new TA program to develop a national integrated logistics development plan.

The knowledge work in India has paved the way to provide front-end analysis to help the partners identify and develop transformative projects. It has been valued by the national partners and given $\mathrm{ADB}$ an opportunity to contribute knowledge inputs at important national forums such as the state investor summits and conferences related to national flagship programs. 


\section{THE FUTURE}

ADB's support to India is guided by the new country partnership strategy, 2018-2022, which is closely aligned with government priorities and its flagship programs, including attaining the SDGs and targets under the Intended Nationally Determined Contributions (ADB, 2017). The strategy aims to accelerate economic transformation by building industrial competitiveness, creating jobs, accelerating growth of LIS, and addressing environmental and climate change challenges. The strategy focuses on six sectors: transport, energy, urban, public sector management, agriculture and natural resources, and human development. These goals are also in line with ADB's Strategy 2030, which envisages responding effectively to the changing needs of the developing member countries, and help achieve prosperous, inclusive, resilient, and sustainable growth (ADB, 2018b). Annual lending is envisaged to increase to $\$ 4$ billion, including private operations, compared with an average of $\$ 2.6$ billion per year during 2013-2017. This includes annual investments of $\$ 1$ billion each in economic corridor and in LIS.

In implementing the country partnership strategy, ADB programs will be (i) increasingly driven by strategic studies that will help the government and ADB identify transformative investments; (ii) involve synergistic and cross-sector approaches to drive transformative solutions across public and private sectors; (iii) align with the government's flagship programs, such as for urban transformation, to "value add" and accelerate their implementation; (iv) actively engage in LIS by forging longterm partnerships, focusing on building capacities and systems for development operations; and (v) continue to improve implementation performance through systematic capacity building and cross learning, monitoring and troubleshooting, and knowledge building and dissemination.

ADB's operations are also guided by its longer-term vision, developed in close consultation with its member countries. ADB Board approved its Strategy 2030 in July 2018, which expands its vision and builds on the learnings of the earlier Strategy 2020. While the focus will continue to be on infrastructure investments-particularly those that are green, sustainable, inclusive, and resilient, ADB also aims to strengthen operations in social sectors, such as education, health, and social protection. Its support will focus on seven operational priorities: (i) addressing remaining poverty and reducing inequalities; (ii) accelerating progress in gender equality; (iii) tackling climate change, building climate and disaster resilience, and enhancing environmental sustainability; (iv) making cities more livable; (v) promoting rural development and food security; (vi) strengthening governance and institutional capacity; and (vii) fostering regional cooperation and integration. ADB will continue to leverage finance, knowledge, and partnerships to sustain its efforts. In this context, country-focused approach will be taken by developing a custom tailored strategy and programs, promoting the use of innovative technologies, and delivering integrated solutions that combine sectors and themes through a mix of public and private sector operations. 


\section{REFERENCES}

Asian Development Bank (ADB). 2013. India Solar Power: Here Comes the Sun in Gujarat. Manila.

ADB. 2016. Development Effectiveness Report 2016 Private Sector Operations. Manila.

2017. Country Partnership Strategy: India, 2018-2022-Accelerating Inclusive Economic Transformation. Manila.

2018a. Asian Development Outlook Update: Maintaining Stability Amid Heightened Uncertainty. Manila.

2018b. Strategy 2030: Achieving a Prosperous, Inclusive, Resilient, and Sustainable Asia and the Pacific. Manila.

Government of India, (GOI) Planning Commission. 2013. Press Note on Poverty Estimates, 2011-12. New Delhi.

GOI. 2017a. Achieving Millennium Development Goals Target Year Factsheet - India. Central Statistical Organization. Ministry of Statistics and Programme Implementation. New Delhi.

2017b. India: Three Year Action Agenda 2017-18 to 2019-20. NITI Aayog. New Delhi.

2017c. Doubling Farmers' Income: Rationale, Strategy, Prospects and Action Plan. NITI Policy Paper No. 1/2017. NITI Aayog. New Delhi.

_ 2018a. Economic Survey 2017-18. Ministry of Finance. New Delhi.

2018b. Annual Report 2017-18. Ministry of Road Transport and Highways. New Delhi.

2018c. Budget 2018-2019. Ministry of Finance. New Delhi. 


\section{Development Effectiveness Brief: India and ADB}

Three Decades of Enduring Partnership

This publication examines how operations of the Asian Development Bank (ADB) have improved the lives of people in India. It also looks at the challenges that ADB and India face in pursuing agreed development goals. The ADB Results Framework indicators are used to report the bank's country-level performance in this Development Effectiveness Brief, which complements the annual Development Effectiveness Review.

\section{About the Asian Development Bank}

$A D B$ is committed to achieving a prosperous, inclusive, resilient, and sustainable Asia and the Pacific, while sustaining its efforts to eradicate extreme poverty. Established in 1966, it is owned by 67 members48 from the region. Its main instruments for helping its developing member countries are policy dialogue, loans, equity investments, guarantees, grants, and technical assistance. 